EUGENIO APOLLINARE MONTICONE

GERENCIAMENTO DE FLUXOS VEICULARES URBANOS POR MEIO DE UM SIMULADOR AGREGADO: PROPOSTA DE UM NOVO TIPO DE SIMULAÇÃO POR SISTEMAS HÍBRIDOS 

EUGENIO APOLLINARE MONTICONE

GERENCIAMENTO DE FLUXOS VEICULARES URBANOS POR MEIO DE UM SIMULADOR AGREGADO: PROPOSTA DE UM NOVO TIPO DE SIMULAÇÃO POR SISTEMAS HÍBRIDOS

Dissertação apresentada à Escola Politécnica da Universidade de São Paulo para obtenção de Mestre em Ciências.

São Paulo 

EUGENIO APOLLINARE MONTICONE

\section{GERENCIAMENTO DE FLUXOS VEICULARES URBANOS POR MEIO DE UM SIMULADOR AGREGADO: PROPOSTA DE UM NOVO TIPO DE SIMULAÇÃO POR SISTEMAS HÍBRIDOS}

Dissertação apresentada à Escola Politécnica da Universidade de São Paulo para obtenção de Mestre em Ciências.

Área de Concentração:

Engenharia de Sistemas Eletrônicos Orientador: Prof. Dr. Marcio Lobo Netto

São Paulo 
Este exemplar foi revisado e corrigido em relação à versão original, sob responsabilidade única do autor e com a anuência de seu orientador.

São Paulo, de março de 2015.

Assinatura do autor

Assinatura do orientador

Catalogação-na-publicação

Monticone, Eugenio Apollinare

Gerenciamento de fluxos veiculares urbanos por meio de um simulador agregado: proposta de um novo tipo de simulação por sistemas híbridos / E.A. Monticone. -- versão corr. -- São Paulo, 2015.

$119 \mathrm{p}$.

Dissertação (Mestrado) - Escola Politécnica da Universidade de São Paulo. Departamento de Engenharia de Sistemas Eletrônicos.

1.Transporte urbano (Modelos; Fluxo) 2.Otimização global I.Universidade de São Paulo. Escola Politécnica. Departamento de Engenharia de Sistemas Eletrônicos II.t. 


\section{AGRADECIMENTOS}

Agradeço meu professor e orientador Marcio Lobo Netto, por ter me apoiado e guiado nos meus anos na Escola Politécnica e pela preciosa ajuda na redação deste texto.

Agradeço minha amiga Carol pelo suporte prático e moral em muitas tardes escrevendo e relendo.

Enfim agradeço a escola italiana Eugenio Montale que me deu subsistência trabalhando tão pouco, ao longo dos anos de estudo. 



\section{RESUMO}

O trânsito das metrópoles do novo milênio é um dos problemas que mais leva ao desperdício de recursos, com a consequente redução da qualidade de vida nas metrópoles. Os gastos ligados a vários fatores fazem com que o uso do veículo na hora do pico de trânsito seja duas vezes maior que o normal. $O$ trânsito também gera poluição e consequentemente contribui para doenças pulmonares. O problema de planejamento operacional das infraestruturas viárias em uma grande metrópole constitui algo muito complexo. Problemas deste tamanho ainda não podem ser enfrentados, pelos sistemas computacionais modernos, na sua totalidade. Este problema se resolve dividindo as metrópoles em áreas nas quais é possível conduzir estudos que resolvam as situações locais. A circulação entre zonas distantes das metrópoles é suportada pelas vias expressas, as quais podem ser otimizadas globalmente. Com o crescimento das metrópoles e de seu número de veículos, muitas vezes, as infraestruturas ficam inadequadas, fazendo com que parte dos fluxos das vias expressas invadam os bairros. Neste trabalho se propõe fortalecer a capacidade dos bairros de enfrentar as situações de fluxos intensos. O processo proposto é hierárquico tendo uma primeira fase composta de estudos locais efetuados com simulação micro/mesoscópica, e uma sucessiva otimização global baseada nos resultados das locais. O sistema de otimização necessita de um teste que avalia as soluções escolhidas ao longo do processo. Na literatura da engenharia de tráfego se encontram diferentes níveis de análise do trânsito que geram as três categorias de modelos de simulação. Estas categorias ganham os nomes de modelos microscópicos, mesoscópicos e macroscópicos, mas nenhuma se mostra apta a ser utilizada como teste do sistema proposto. Neste trabalho se propõe um simulador que abstrai o conceito de rede viária reduzindo os custos computacionais até conseguir simular uma inteira metrópole. A técnica de estudo proposta, nos testes, se revela útil em determinadas situações, mas ainda deve ser confrontada com as novas tecnologias capazes de refinar os planos operacionais em tempo real na base dos dados de sensores e câmeras espalhados nas infraestruturas.

Palavras-chaves: Modelos agregados de Trânsito. Algoritmos Genéticos. Gestão dos fluxos. 



\begin{abstract}
The traffic of new-millennium metropolises is one of the problems that most cause resources' waste, consequently reducing the quality of life in these metropolises. The costs related to a series of causes make the use of vehicles at rush times be twice as frequent as during other times. The traffic also generates pollution, hence contributing to pulmonary diseases. The infrastructures operational planning problems in big cities is a complex issue. Such big problems still cannot be fully faced by modern computer systems. This can be solved dividing the cities into areas where it is possible to run studies to solve local situations. The circulation between distant areas in metropolises can be done via express motorways, which can be globally improved. With the expansion of big cities and their vehicles, the infrastructures frequently become inadequate and the stream invades neighborhoods. The aim of the present work is to improve the capacity of neighborhoods" streams, offering besides technical norms, a global optimization based on local results. The optimization system needs a test that evaluates the chosen solutions along the process. In traffic engineering literature, there are different levels of traffic analysis that generate the three simulation model categories. These categories are named microscopic, mesoscopic, and macroscopic models, but none of them is able to be used as test to the proposed system. In this work, it is proposed a simulator that abstracts the concept of road network, reducing the computer expenses up to the simulation of a whole city. The study technic pruioposed in the tests shows itself as useful in certain situations, but still must be confronted with new technologies able to refine the operational plans in real time based on the sensors and cameras' data.
\end{abstract}

Keywords: Aggregated Traffic Models. Genetic Algorithm. Fluxes Management. 



\section{LISTA DE FIGURAS}

Figura 1: Rodovia que liga Pequim com Jinin no Tibet. 14 agosto 2010, $100 \mathrm{~km}$ de fila. .23

Figura 2: Concentração do PM10 em São Paulo em dias secos e úmidos. .25

Figura 3: Custos relativos ao uso do veículo privado. .26

Figura 4: Custo da utilização de um carro em diferentes situações. .27

Figura 5: Estudo de viabilidade de duas tipologias de resolução de um cruzamento. Simulador: TSS Aimsun. Estudo para a construção de um retorno no município italiano de Montecosaro. 29

Figura 6: Teste de uma infraestrutura destinada a um trânsito principal; .29

Figura 7: Simulação mesoscópica de uma rede urbana para a sincronização dos semáforos .30

Figura 8: Túnel Presidente Jânio Quadros, São Paulo: flui no sentido Centro [vermelho] entre 04h30min e 09h30min, e muda então de sentido, indo em direção ao Morumbi [amarelo]. 31

Figura 9: Aparelhos semafóricos com sensores disponíveis no mercado. .33

Figura 10: Comunicação entre veículos e infraestruturas. .34

Figura 11: Sistema de alerta de precedência. 35

Figura 12: Sistema de alertas por fechamento das faixas 35

Figura 13: Forma qualitativa do diagrama fundamental do trânsito repartido nas zonas de trânsito livre, com fenômeno de stop and go, trânsito a minhoca, parado.

Figura 14: Diagramas fundamentais do trânsito recavados por simuladores microscópicos. Todos os graficos representam o fluxo ao variar da densidade de veículos. 44

Figura 15: Gráfico dos canos na região do Veneto no norte da Itália. 45

Figura 16: Infraestruturas isolantes classificadas como cano. .45

Figura 17: Infraestruturas porosas classificadas como esponja. 45

Figura 18: Permeabilidade e porosidade de dois tecidos reais. 46

Figura 19: Permeabilidade de dois tecidos teste representadas por os dois autovetores de comprimento proporcional a os autovalores. 
Figura 20: Mapa do território considerado no estudo da viabilidade do projeto Gran Paris.

Figura 21: Exemplo de percurso de busca típico do algoritmo Hill Climbing. 51

Figura 22: Típico andamento do processo de pesquisa por algoritmo Tabu. As áreas mais escuras indicam as regiões com valores elevados. $O$ ponto vermelho indica o ótimo global. 52

Figura 23: Andamento da busca de um processo Tabu na região gerada por um problema VRP com 150 nodos. Pode se ver como a pesquisa continua após os mínimos locais gerando muitas oscilações. 53

Figura 24: Andamento da busca de um processo Tabu na região gerada por um problema VRP com 50 nodos. O baixo número de nós aumenta a probabilidade de ciclos que após algumas iterações são interrompidos pelo sistema randômico. 53

Figura 25: Exemplo de recombinação dos cromossomos dos pais no filho. 56

Figura 26: Espalhamento dos pontos em ausência do parâmetro de separação das espécies. 58

Figura 27: Espécies geradas por AG. As gerações estão no eixo vertical e as pontas das setas indicam a extinção da espécie. 58

Figura 28: Diagrama que representa os blocos do algoritmo. A parte verde representa o simulador utilizado como função de teste pelo algoritmo genético, repetido para cada individuo filho. A parte azul representa 0 interior do ciclo do algoritmo genético repetido para cada geração de indivíduos. 60

Figura 29: Região de São Paulo em volta do estádio de Itaquera com 6 canais de acesso. 61

Figura 30: Fluxos diários da manha na cidade de Roma....................................... 62

Figura 31: Junção de tecidos quadrangulares com blocos triangulares ou pentagonais. 65

Figura 32: Esquema de blocos de diferentes tamanho e fluxos principais da região. 66

Figura 33: Exemplo de subdivisão da borda dos blocos em lados de entrada/saída dos fluxos. 67

Figura 34: Exemplo de matriz de tempos de transferência, com média e variância e esquema de entrada/sida do bloco. 68 
Figura 35: Exemplo de corte mínimo de um bloco e relativos caminhos. .70

Figura 36: Dados necessário para cada cruzamento da rede.

Figura 37: Exemplo de intercambo dos veículos no modelo de assinação probabilística de rota. .73

Figura 38: Cálculo das rotas principais na região do estádio de Itaquera. ................75

Figura 39: Exemplo de bloco e gráficos das probabilidades reais ao variar dos veículos $N_{v}$ no arco principal entre 0 e 1000 (dados da Tabela 6). .77

Figura 40: Região em torno do estádio de Itaquera com as 6 entradas, 25 blocos e as rotas principais e internas. .80

Figura 41: Rotas e desvios na região (arcos). .81

Figura 42: Exemplo de cromossomo, em cores diferentes os genes .84

Figura 43: Soluções mínimas encontradas para a função de Levy de dez e quatrocentas dimensões ao crescer do número de bits utilizados para cada asse. .85

Figura 44: Diagrama de fluxo do algoritmo genético. .88

Figura 45: Hierarquia das funções no Simulador. .94

Figura 46: Hierarquia das funções no processo de otimização. 94

Figura 47: Amplitude das funções de otimização em proporção a própria media. Para fim de clareza as duas funções foram escaladas para ter média no 100. .97

Figura 48: Rotas efetivas dos veículos. .98

Figura 49a-b: Solução ótima encontrada em dois névies de trânsito .99

Figura 50a-b-c: Processo evolutivo tendo uma instancia composta de cerca 5.000 25.000 e 50.000 veículos. 100 


\section{LISTA DE TABELAS}

Tabela 1: Aumento da frota brasileira de veículos em deis anos............................ 24

Tabela 2 : Exemplo de cálculo da média do tempo de travessia de um bloco.......... 70

Tabela 3: Cálculo das probabilidades dos arcos. .................................................... 77

Tabela 4: Exemplo de vetor de carga para um bloco de entrada. .......................... 82

Tabela 5: Cálculo das probabilidade de ser Pai a partir do valor de fitness.............. 89

Tabela 6: Cálculo da probabilidade de ser Pai a partir do valor de fitness.

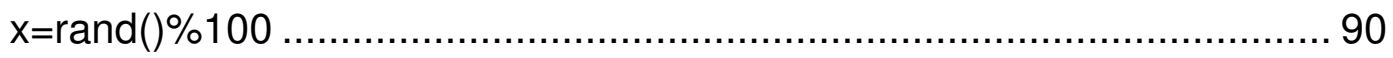

Tabela 7: Medida experimental da constante da função do custo computacional .... 95

Tabela 8: Margem teórico de melhoramento ....................................................... 96 


\section{LISTA DE QUADROS}

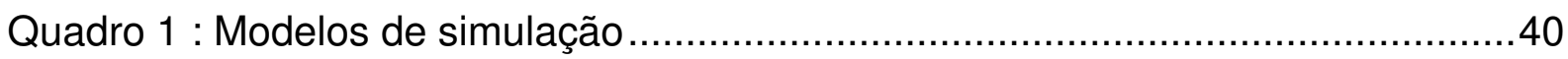

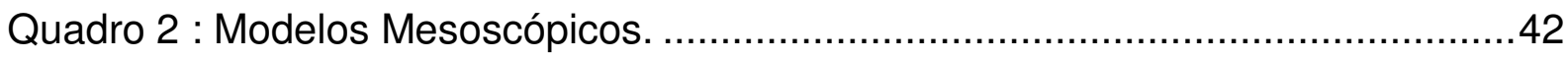

Quadro 3 : Diagramas fundamentais do trânsito recavados por simuladores

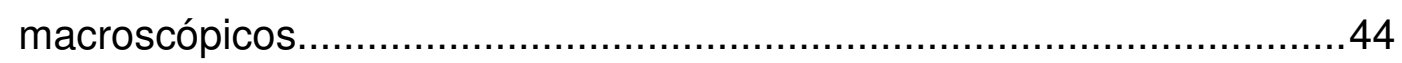

Quadro 4 : Conteúdo da estrutura de dados principal do simulador ........................91

Quadro 5 : Conteúdo das estruturas dos arcos..................................................92 


\section{LISTA DE EQUAÇÕES}

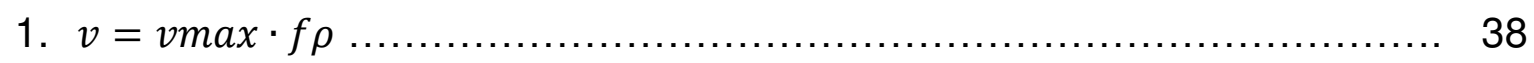

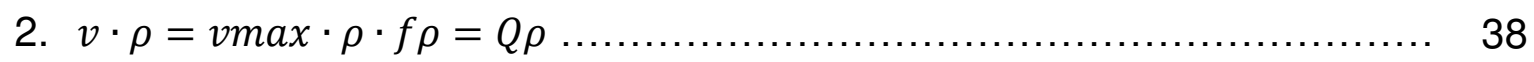

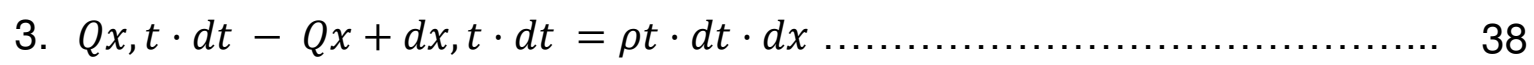

4. $-Q x=\rho x \cdot Q(\rho) \rho=-v \max \rho x \cdot f \rho+\rho \cdot f x \rho=-v \max \cdot \rho x f+\rho \cdot f \rho=\rho t \quad 39$

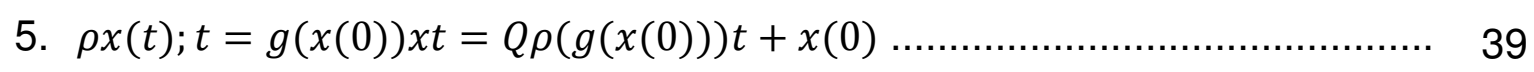

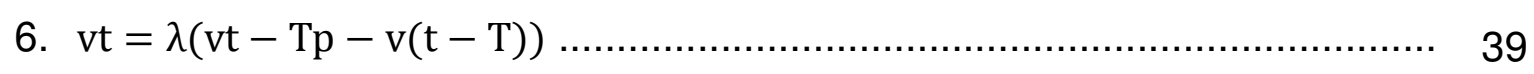

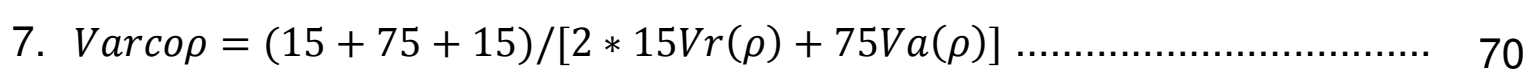

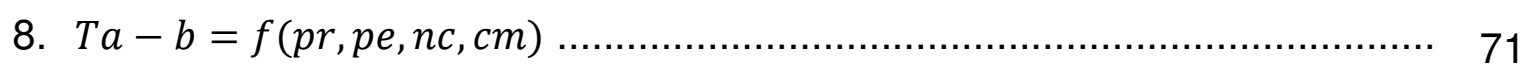

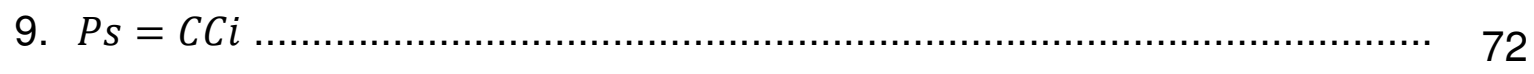

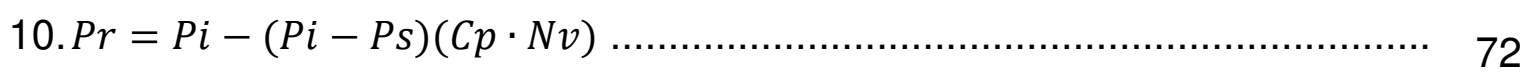

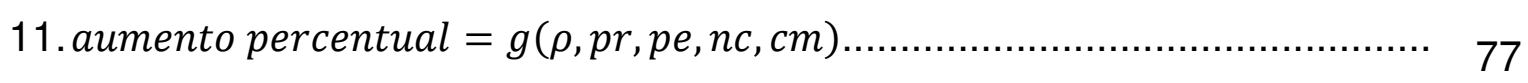

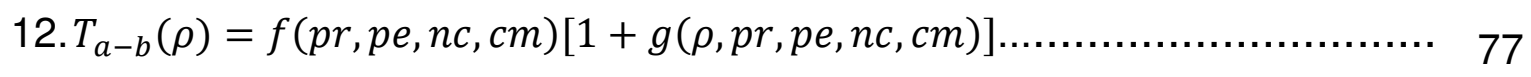

13. $f x=\sin 23 \pi \cdot y 1+y n-12 \cdot 1+\sin 22 \pi \cdot y n+i=1 n y i-12 \cdot 1+\sin 23 \pi$.

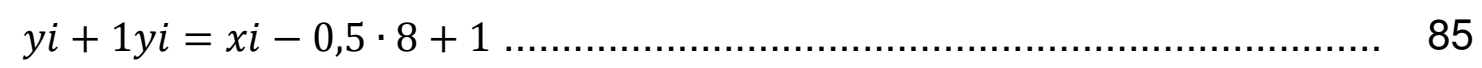

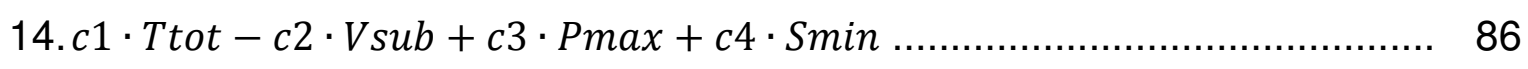

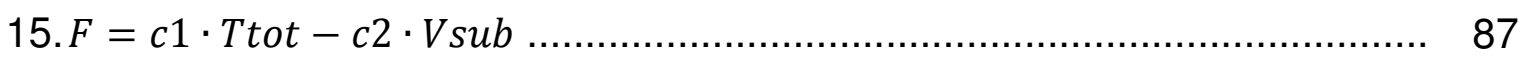

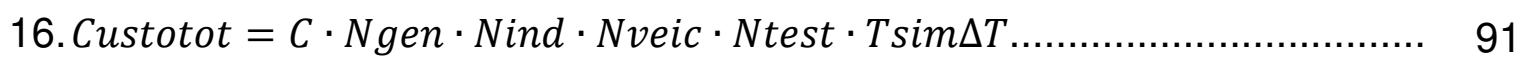




\section{LISTA DE ABREVIATURAS E SIGLAS}

AG

CET-SP

ITS

EP-USP

$\mathrm{PM}_{10}$

LWR
Algoritmo genético

Companhia de Engenharia de Tráfego de São Paulo

Intelligent Transportation Systems

Escola Politécnica da Universidade de São Paulo

Partículas com diâmetro menor de $10 \mu \mathrm{m}$, em suspensão na ar e nocivas para o aparato respiratório.

Modelo de trânsito macroscópico de Lighthill-Whitham-Richard (Quadro 1, seção 2.1.3) 



\section{SUMÁRIO}

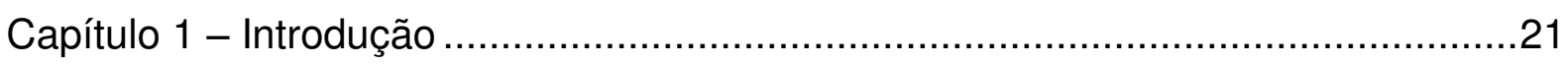

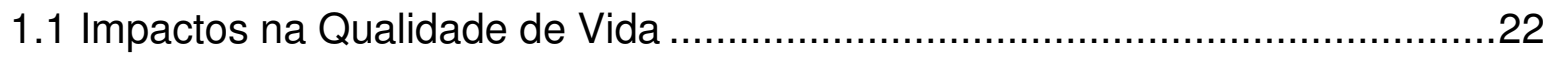

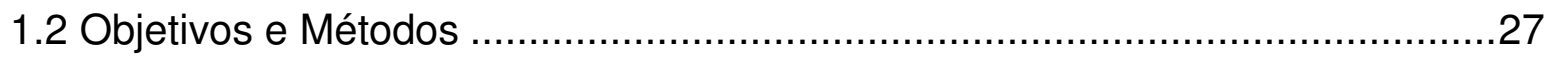

1.2.1 Planejamento e dimensionamento de infraestruturas ...............................28

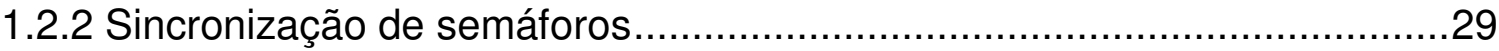

1.2.3 Planejamentos especiais de semáforos e faixas .....................................31

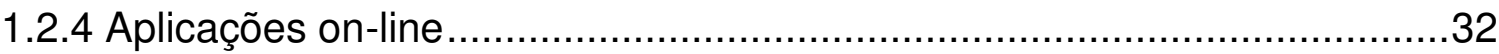

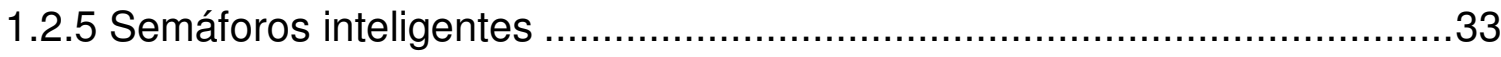

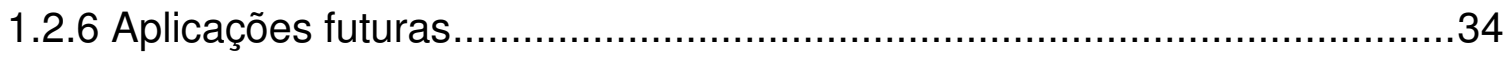

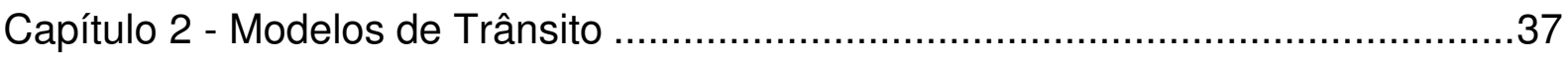

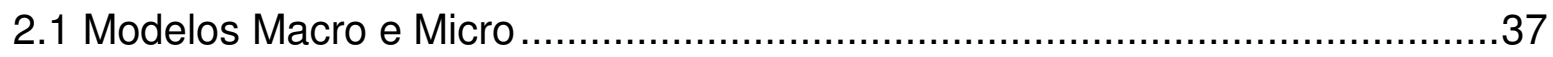

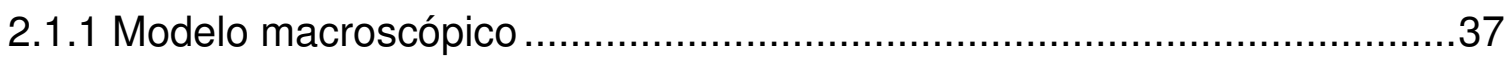

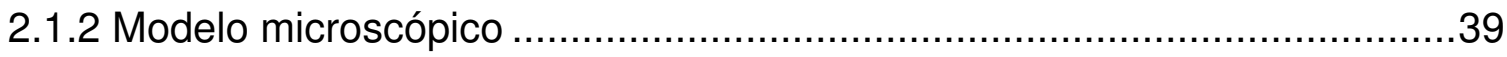

2.1.3 Desempenho dos modelos ……...........................................................

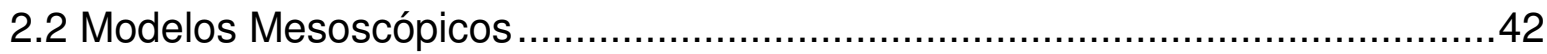

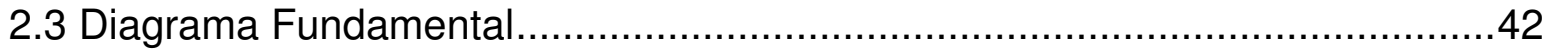

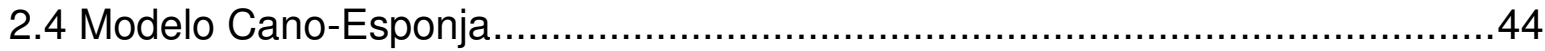

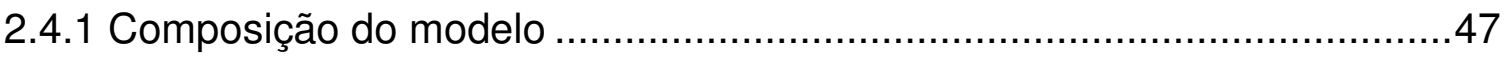

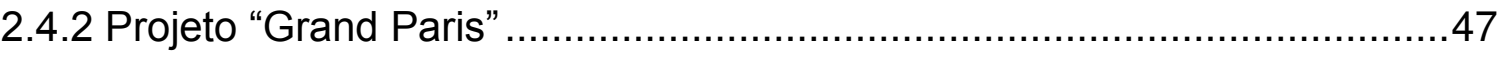

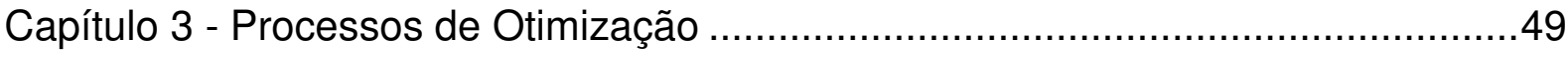

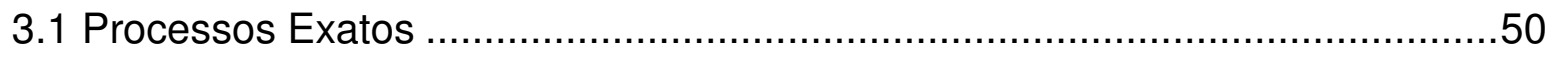

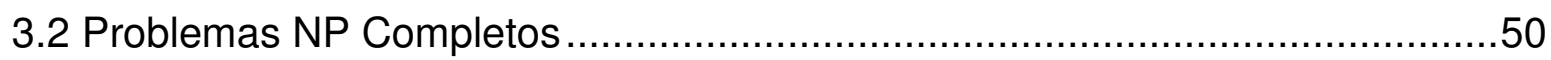

3.3 Processos Monótonos Crescentes............................................................

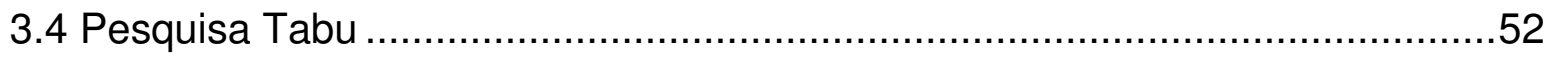

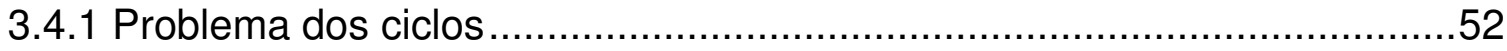




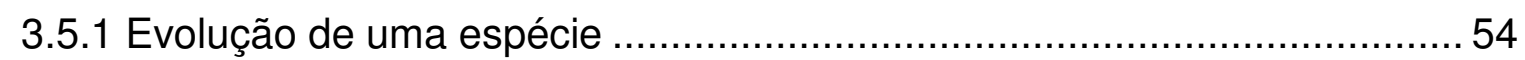

3.5.2 Características dos algoritmos genéticos ………….............................. 55

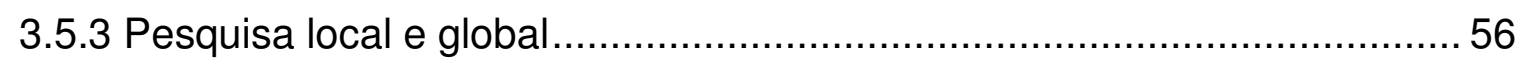

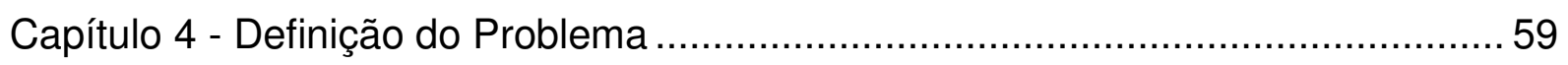

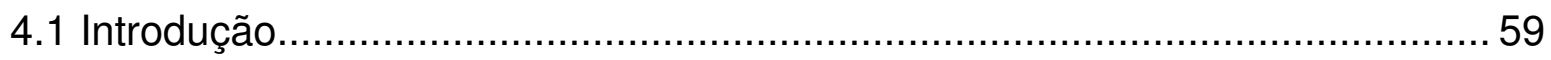

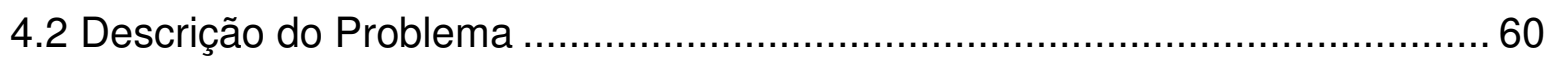

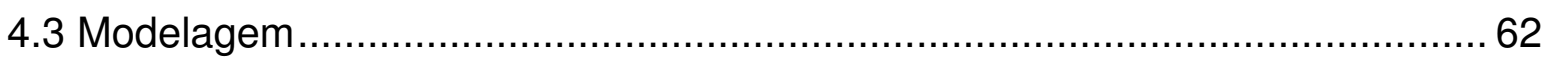

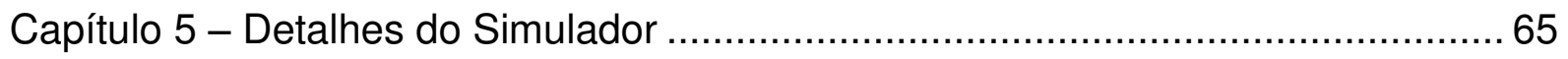

5.1 Decomposição da Rede Viária em Blocos.................................................... 65

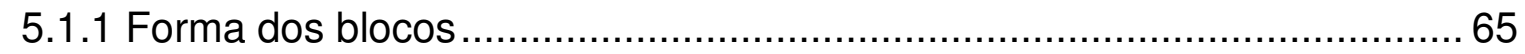

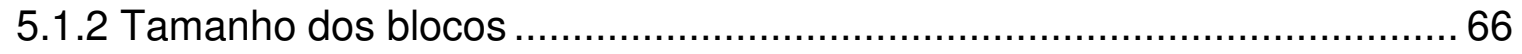

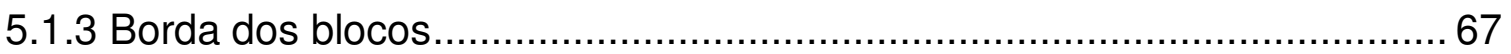

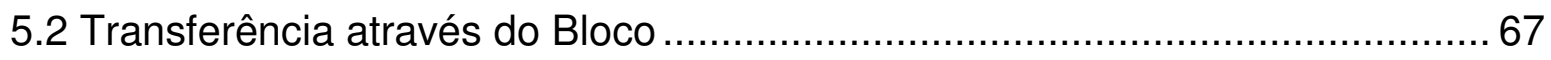

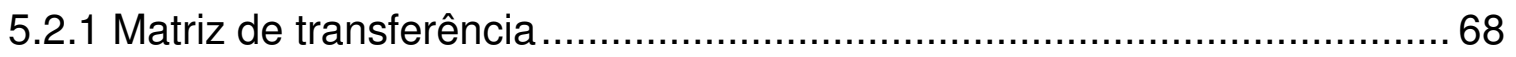

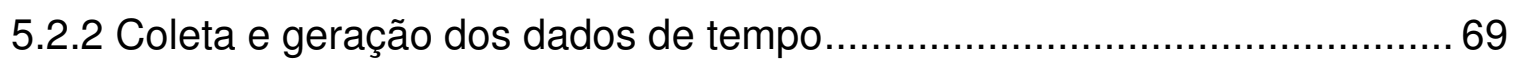

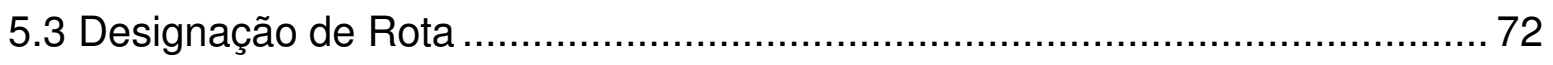

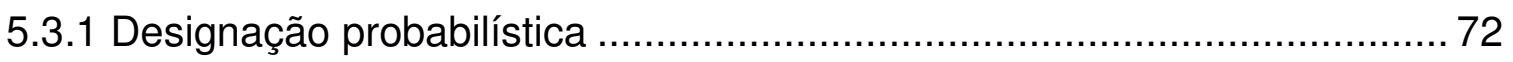

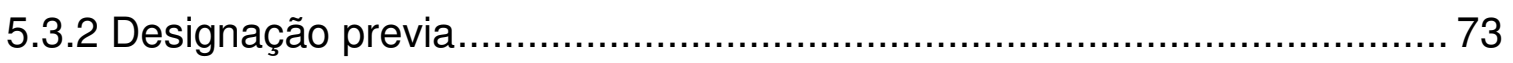

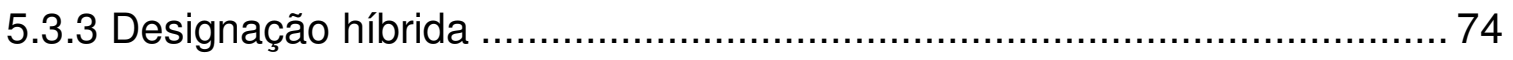

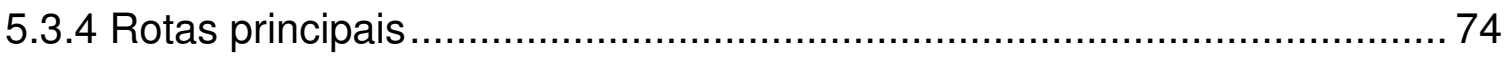

5.3.5 Encaminhamento dos fluxos principais .............................................. 75

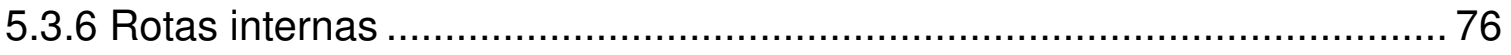

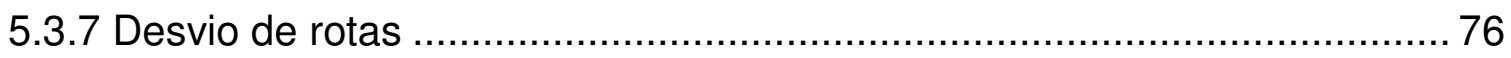

5.4 Presença do Trânsito Subjacente........................................................... 78

5.5 Discretização Temporal e Duração da Simulação .......................................... 78

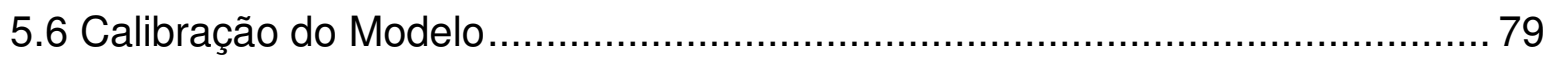


5.7 Resumo dos Dados Iniciais .80

Capítulo 6 - Otimização .83

6.1 Domínio e Teste .83

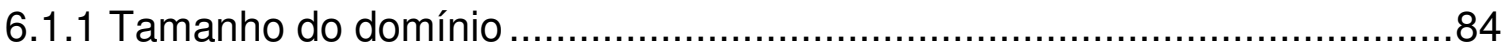

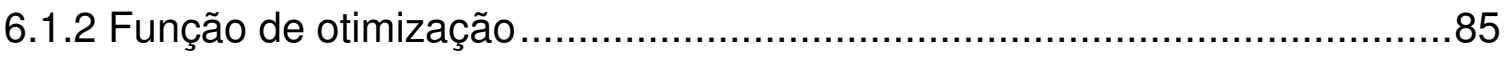

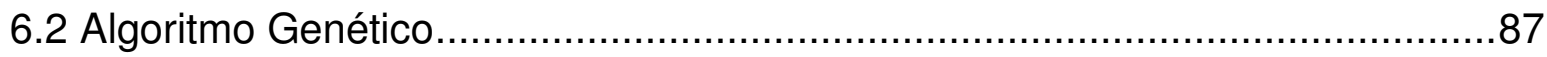

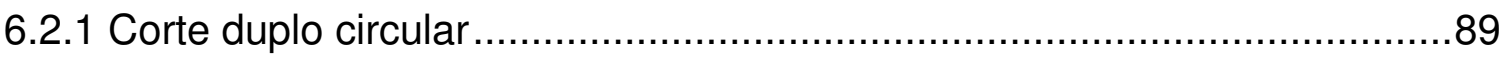

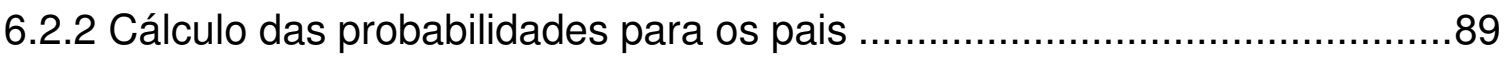

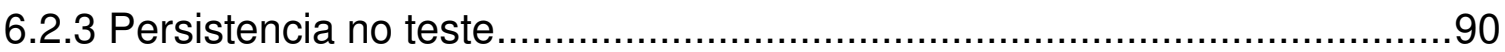

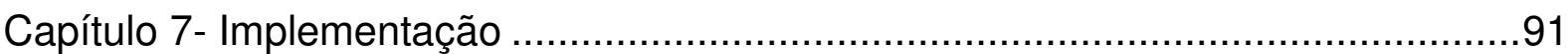

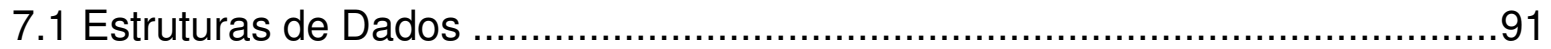

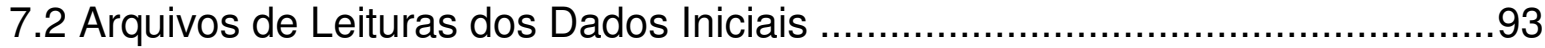

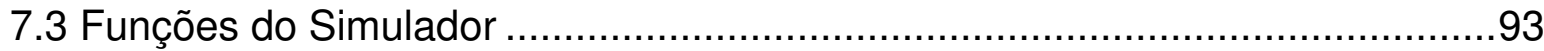

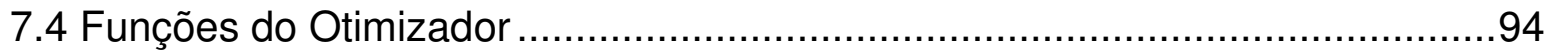

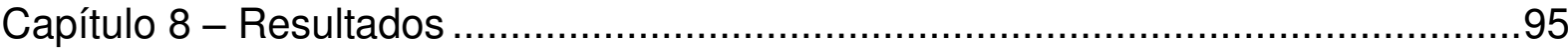

Teste 1: Velocidade da simulação ……………….......................................95

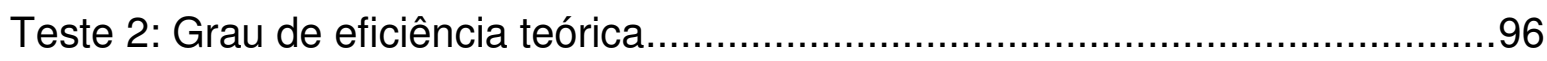

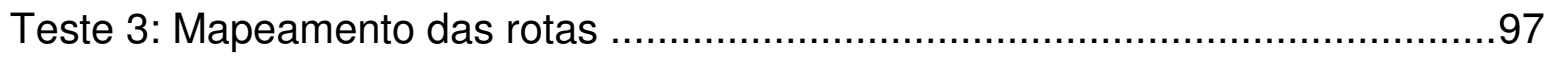

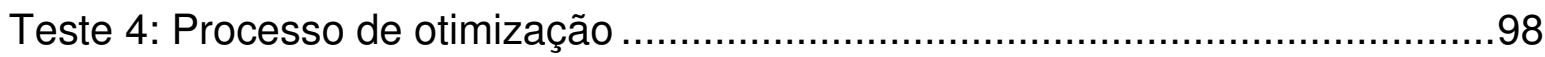

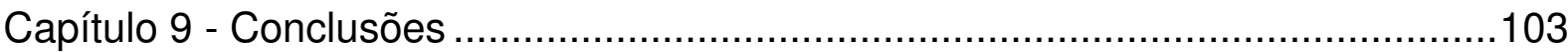

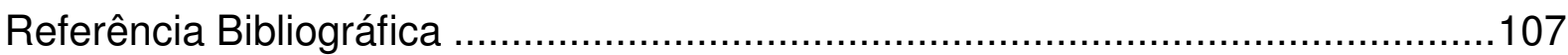

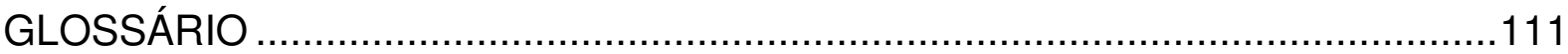

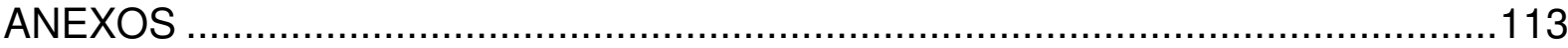

A1 Mercado da Simulação de Trânsito ...........................................................113

A1.1 Macroscópicos ............................................................................113

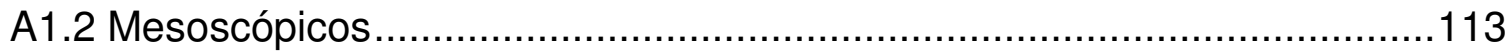

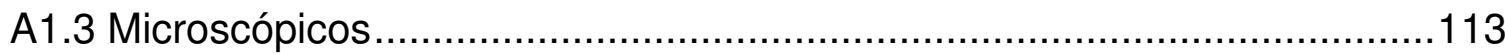




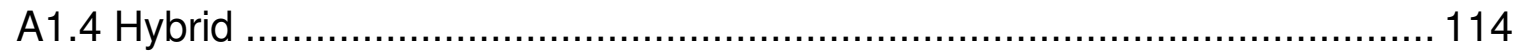

A2 Estruturas de dados ....................................................................... 114

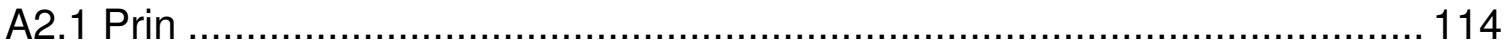

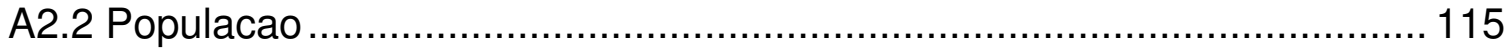

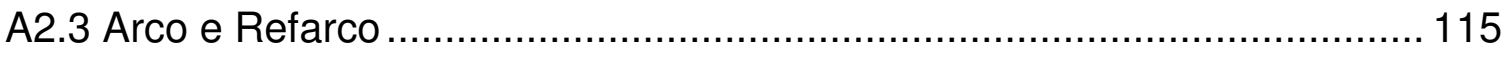

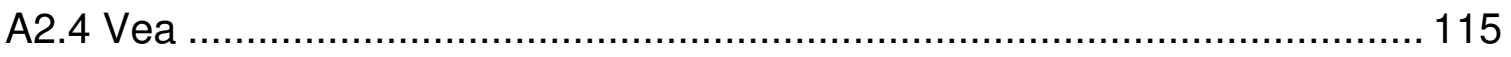

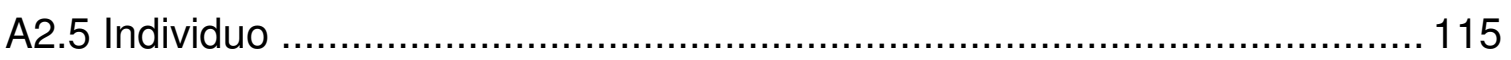

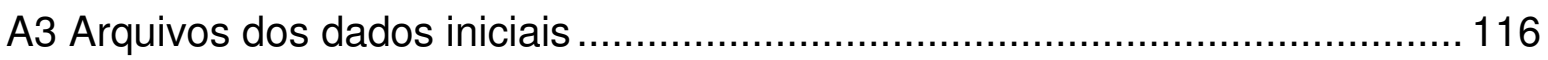

A3.1 load_data_map .................................................................. 116

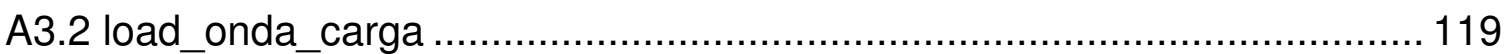




\section{Capítulo 1 - Introdução}

Esta dissertação tem por fim avaliar a factibilidade de uma nova modalidade de estudo, análise e simulação do trânsito urbano. Esta nova abordagem pretende melhorar o nível de eficiência da rede viária utilizando um processo hierárquico de otimização do plano operacional. O sistema se compõe de uma serie de otimizações locais seguida no nível superior por uma otimização global que estuda as interações entre os bairros da metrópole. Os aspectos avaliados são a velocidade de cálculo computacional executado pelo sistema proposto e a possibilidade teórica de obter melhorias através o uso desta abordagem.

A solução comumente utilizada prevê um estudo global que considera só as vias de hierarquia mais alta (rodovias e vias de grande porte), e uma série de estudos de otimizações locais nos bairros. A abordagem proposta pretende melhorar o fator de interação entre os planos operacionais locais usando uma estrutura hierárquica, para assim gerar uma melhoria global do transito. A proposta prevê não implantar diretamente os resultados das otimizações locais, mas proceder hierarquicamente com um segundo processo de otimização global baseado nos mesmos resultados. A ideia de experimentar um nível superior de otimização decorre do fato de que um estudo local de otimização fornece muitos planos operacionais ótimos e não somente um. A ideia é coletar estes resultados a partir de muitas simulações locais e escolher o plano para ser utilizado em cada bairro através um estudo de otimização global. Esta fase poderia buscar assim as melhores combinações de planos operacionais locais para que seja melhorada também a circulação global. Para fazer isso é preciso formalizar um teste para avaliar cada combinação dos planos locais, devendo este teste ser feito por um simulador capaz de gerenciar o domínio global da metrópole. Para obter rapidez no cálculo é preciso admitir aproximações e assim erros que limitam a correspondência dos resultados com a realidade. Através do uso de planos operacionais localmente ótimos se consegue garantir, em termos probabilísticos, uma melhoria no desempenho geral. Neste trabalho enfim se apresenta um protótipo de simulador que pode ser utilizado para esta finalidade. 
O propósito deste texto é apresentar esta ideia que se concretiza em um novo nível de simulação do trânsito urbano e dar uma primeira contribuição para sua realização. Conjuntamente ao novo sistema se apresenta, como exemplo de aplicação, o estudo dos bairros em volta do novo estádio de Itaquera construído para a copa 2014. Nestes bairros se prevê que a condição de trânsito no período que antecede os jogos terá um padrão representativo da utilização do simulador apresentado neste trabalho. O sistema de simulação proposto foi implementado e foram conduzidos vários testes. Os resultados são catalogados no capítulo $8 \mathrm{e}$ avaliam o custo computacional exigido, a margem de ganho possível em termos de menor lentidão e a distribuição qualitativa dos veículos que escolhem um desvio da lentidão. Sendo uma dissertação de Mestrado, o texto tem amplo espaço para o levantamento da literatura da engenharia de trânsito, que se estende pelos primeiros três capítulos.

\subsection{Impactos na Qualidade de Vida}

A história da vida no nosso planeta se inicia com uma "célula" há alguns bilhões de anos. A partir daquele momento os princípios evolucionários começaram a diferenciar e selecionar espécies e indivíduos fazendo com que a vida fosse sempre mais adaptada ao ambiente, conseguindo assim uma sobrevivência mais fácil. $\mathrm{A}$ nossa espécie além da adaptação conseguiu constituir uma cultura coletiva capaz de gerar situações sempre mais confortáveis para a condução da nossa vida. Inicialmente foi o fogo e depois a roda, a agricultura e a criação de animais úteis. $\mathrm{E}$ então vieram os primórdios de tecnologia na edificação de casas e obras públicas e a medicina. No nosso século temos água em casa, meios de informação poderosos e no âmbito da mobilidade o produto que é o ápice da tecnologia é o carro motorizado. Um dos princípios base que regulam o mundo está relacionado à tendência da vida atingir condições sempre mais agradáveis e também nós humanos, como espécie e como indivíduos, estamos à procura de melhorias para o nosso estilo de vida. O bem estar na sociedade é tão importante que geramos métodos e índices para a avaliação dos ambientes onde moramos assim podemos confrontar objetivamente a condição oferecida em diferentes lugares do mundo. Nas cidades a mobilidade representa um fator muito importante para o índice de 
qualidade de vida dos moradores, e o veículo privado foi uma grande mudança para a mobilidade pessoal dos indivíduos permitindo que a partir de vilas ajustadas à escala humana chegássemos a metrópoles adequadas para o carro. O carro permite viajar para qualquer lugar, a qualquer momento, por qualquer motivação, mas nas ultimas décadas esta liberdade de movimento esta sendo prejudicada por causa dos problemas de trânsito. A velocidade média dos carros no horário de pico muitas vezes é parecida à velocidade dos pedestres e quase sempre menor da velocidade média de uma bicicleta. O objeto que deu a liberdade de movimento agora a tira por causa da excessiva quantidade de veículos e da difícil gestão deles. (Norberto, 2010)

Figura 1: Rodovia que liga Pequim com Jinin no Tibet. 14 agosto 2010, 100 km de fila.

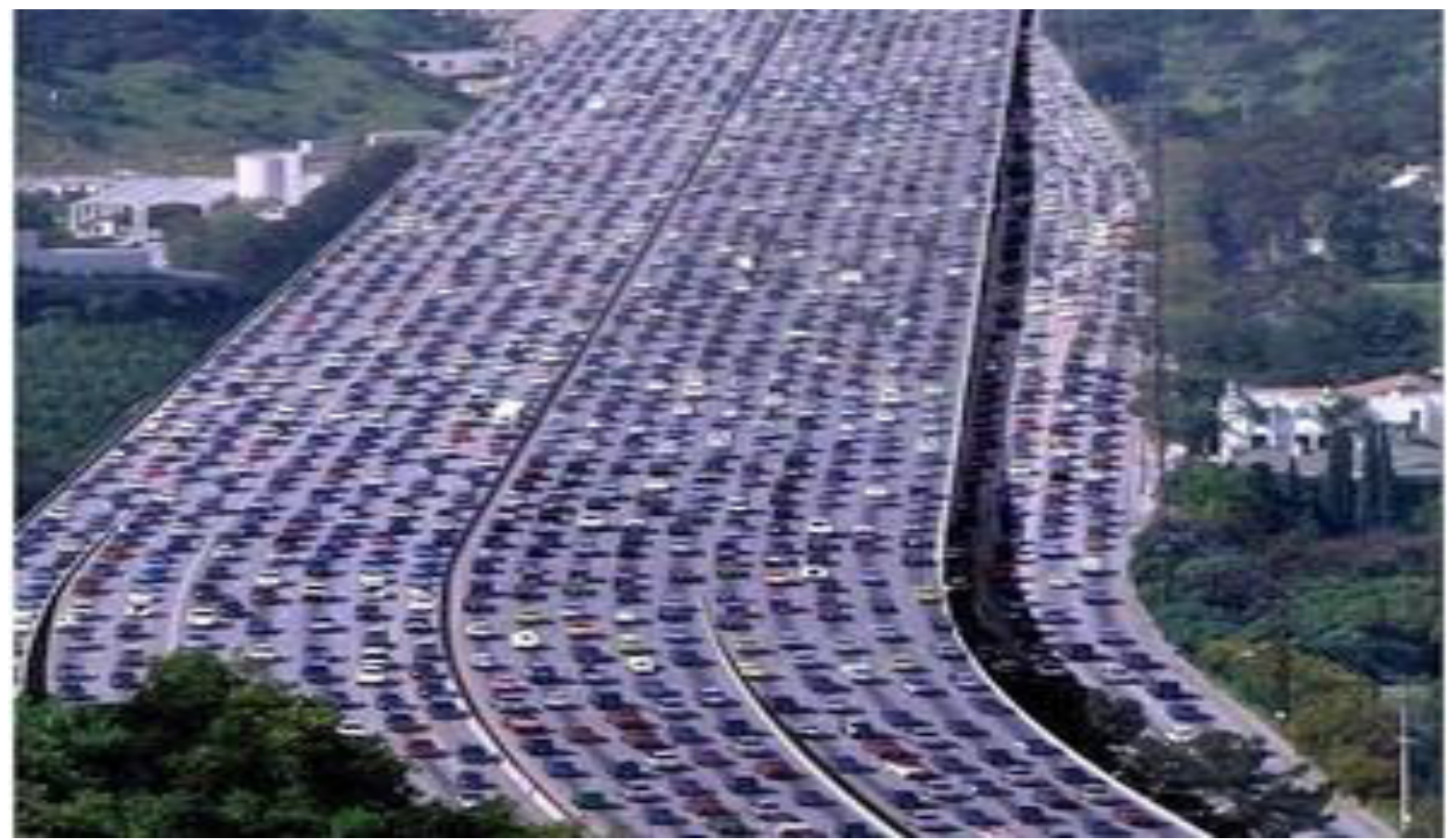

Fonte: ADS-News

A Figura 1 mostra aquele que é considerado o pior engarrafamento de trânsito já registrado, acontecido no dia 14 de agosto de 2010 e solucionado apenas no dia 26 do mesmo mês, aparecendo em comentários de muitos jornais como: "The Guardian”, "New York Times" e "The Economist”. (Hickman, 2010) (The great crawl of China, 2010) (Wines, 2010) (Watts, 2010)

A Tabela 1 mostra o crescimento do número de veículos em cada estado do Brasil entre os anos de 2001 e 2011. É fácil constatar que as construções de obras viárias 
não seguiram o mesmo crescimento, em particular nas áreas metropolitanas onde não há espaço para o alargamento das vias e o valor da construção de obras é muito alto. $O$ resultado é a percepção sempre maior de que o carro privado não garante a nossa liberdade de movimento e de que a ida e volta do trabalho ou uma saída para a praia no fim de semana podem significar horas de stress no trânsito. $\mathrm{Na}$ cidade de São Paulo, a cada manhã se mede entre 100 e $150 \mathrm{~km}$ de lentidão, que além do gasto de tempo e combustível, causam poluição e transtorno, e levam a uma trágica soma de 1300 mortos por ano, 100 feridos por dia, mais os prejuízos a bens privados e públicos.

Tabela 1: Aumento da frota brasileira de veículos em deis anos.

Frota Brasileira por Estado de 2001 a 2011

\begin{tabular}{|c|c|c|c|c|}
\hline & Estado do Brasil & 2001 & 2011 & Variação \\
\hline 1 & Tocantins & 104.624 & 437.345 & $318 \%$ \\
\hline 2 & Maranhão & 227.095 & 942.639 & $315 \%$ \\
\hline 3 & Amapá & 33.117 & 130.388 & $294 \%$ \\
\hline 4 & Acre & 47.003 & 170.439 & $263 \%$ \\
\hline 5 & Piauí & 185.211 & 671.146 & $262 \%$ \\
\hline 6 & Pará & 313.900 & 1.109 .264 & $253 \%$ \\
\hline 7 & Roraima & 41.737 & 139.090 & $233 \%$ \\
\hline 8 & Rondônia & 190.719 & 634.416 & $233 \%$ \\
\hline 9 & Mato Grosso & 421.178 & 1.303 .902 & $210 \%$ \\
\hline 10 & Bahia & 882.063 & 2.585 .655 & $193 \%$ \\
\hline 11 & Rio Grande do Norte & 276.620 & 807.874 & $192 \%$ \\
\hline 12 & Paraíba & 272.766 & 794.093 & $191 \%$ \\
\hline 13 & Amazonas & 203.361 & 589.780 & $190 \%$ \\
\hline 14 & Ceará & 699.877 & 1.947 .552 & $178 \%$ \\
\hline 15 & Sergipe & 178.920 & 480.287 & $168 \%$ \\
\hline 16 & Alagoas & 184.710 & 495.715 & $168 \%$ \\
\hline 17 & Goiás & 1.033 .056 & 2.679 .948 & $159 \%$ \\
\hline 18 & Pernambuco & 794.160 & 1.996 .714 & $151 \%$ \\
\hline 19 & Espirito Santo & 548.985 & 1.367 .967 & $149 \%$ \\
\hline 20 & Mato Grosso do Sul & 434.566 & 1.064 .852 & $145 \%$ \\
\hline 21 & Santa Catarina & 1.588 .549 & 3.679 .482 & $132 \%$ \\
\hline 22 & Minas Gerais & 3.416 .476 & 7.662 .556 & $124 \%$ \\
\hline 23 & Paraná & 2.557 .536 & 5.558 .521 & $117 \%$ \\
\hline 24 & Distrito Federal & 645.133 & 1.331 .933 & $106 \%$ \\
\hline 25 & São Paulo & 11. 348.349 & 21.968 .359 & $94 \%$ \\
\hline 26 & Rio Grande do Sul & 2. 706.175 & 5.149 .420 & $90 \%$ \\
\hline 27 & Rio de Janeiro & 2.577 .117 & 4.844 .198 & $88 \%$ \\
\hline & Brasil & 31.913.003 & 70.543 .535 & $121 \%$ \\
\hline
\end{tabular}

Fonte: Automotive-Business 
As avenidas principais registraram uma queda de velocidade, como no caso da Av. Rebouças que nos dez anos considerados teve uma variação da velocidade média na hora de pico de 17,9 km/h para 7,6 km/h. Mesmo assim ainda se fala de meses recordes para a venda de veículos como em agosto 2012 no qual foram vendidos 580.843 veículos no país, com um crescimento do $10,18 \%$ a cima das vendas do mesmo mês do ano anterior. (Globo, 2012) (Fenabrave)

O trânsito não compromete a qualidade de vida só dos automobilistas, mas de toda a população. Entres os maiores problemas ligados ao trânsito estão os barulhos produzidos pelos motores e sinalizações sonoras que perturbam as pessoas nas noites, e nos feriados, bem como a geração de gases nocivos para a saúde da população. $\mathrm{O} \mathrm{PM}_{10}$ é reconhecido como causa de muitas doenças quem afetam idosos e crianças como asma, afeições cardiopulmonares e insuficiência pulmonar.

Figura 2: Concentração do PM10 em São Paulo em dias secos e úmidos.

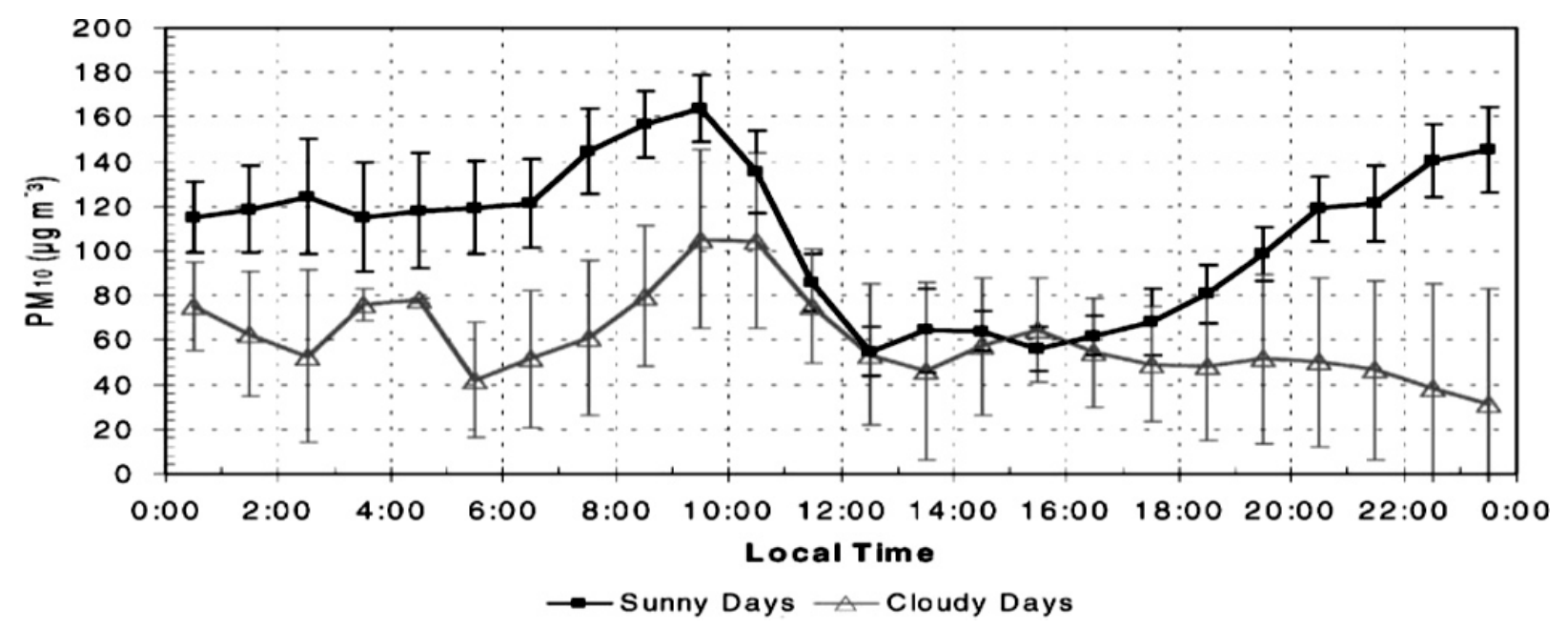

Fonte: Science-Direct. Castanho; Artaxo (2001)

O gráfico da Figura 2 mostra a variabilidade da concentração de $\mathrm{PM}_{10}$ na cidade de São Paulo ao longo de um dia da semana. A primeira coisa que se pode ver é a ligação entre as subidas do gráfico e os horários de pico do trânsito na cidade, em detalhe se pode ver um crescimento rápido por volta das oito da manha e das sete da tarde. Esta correspondência, do gráfico relativo aos dias secos com os horários de pico do trânsito, indica obviamente que os carros contribuem de maneira fundamental na geração destas partículas perigosas. Como se pode ver na época úmida do ano a cidade é mais protegida da difusão do $\mathrm{PM}_{10}$, por causa da chuva que diminui a volatilização das partículas. Este efeito è tão intenso que no gráfico relativo aos dias nublados não se releva o crescimento das partículas em correspondência 
do pico de saída dos trabalhadores que em geral é acompanhada da típica garoa de fim da tarde do São Paulo. (Castanho \& Artaxo, 2001)

A necessidade de melhorar a mobilidade em todas as grandes cidades do mundo é um problema de primeira importância que ainda não tem uma solução eficaz e concretizável considerando os limites computacional, econômico e de tempo das nossas metrópoles. Uma série de medidas, como o rodízio dos veículos (a partir de restrições impostas em função de suas placas), fim de semana sem carro, zonas de pedestres, estacionamentos pagos, ajudam o controle das emissões, mas sem resolver o problema da liberdade de movimento porque colocam limites para o uso do veículo privado. Para que a liberdade de movimento seja preservada, a escolha de não utilizar o carro, mas de outros meios, deve ser individual e surgir no cidadão no momento que os veículos públicos são percebidos como mais adequados. As medidas nesta direção são principalmente o fortalecimento das linhas de ônibus e trem urbanos ou suburbanos, o car sharing e as políticas de educação da população enquanto valorizam os benefícios gerais do transporte público frente à pouca eficiência do veículo privado. O uso de veículos motorizados tem um grande número de repercussões fazendo da quantificação dos custos ambiental e econômico do trânsito um trabalho muito complexo (Figura 3).

Figura 3: Custos relativos ao uso do veículo privado.

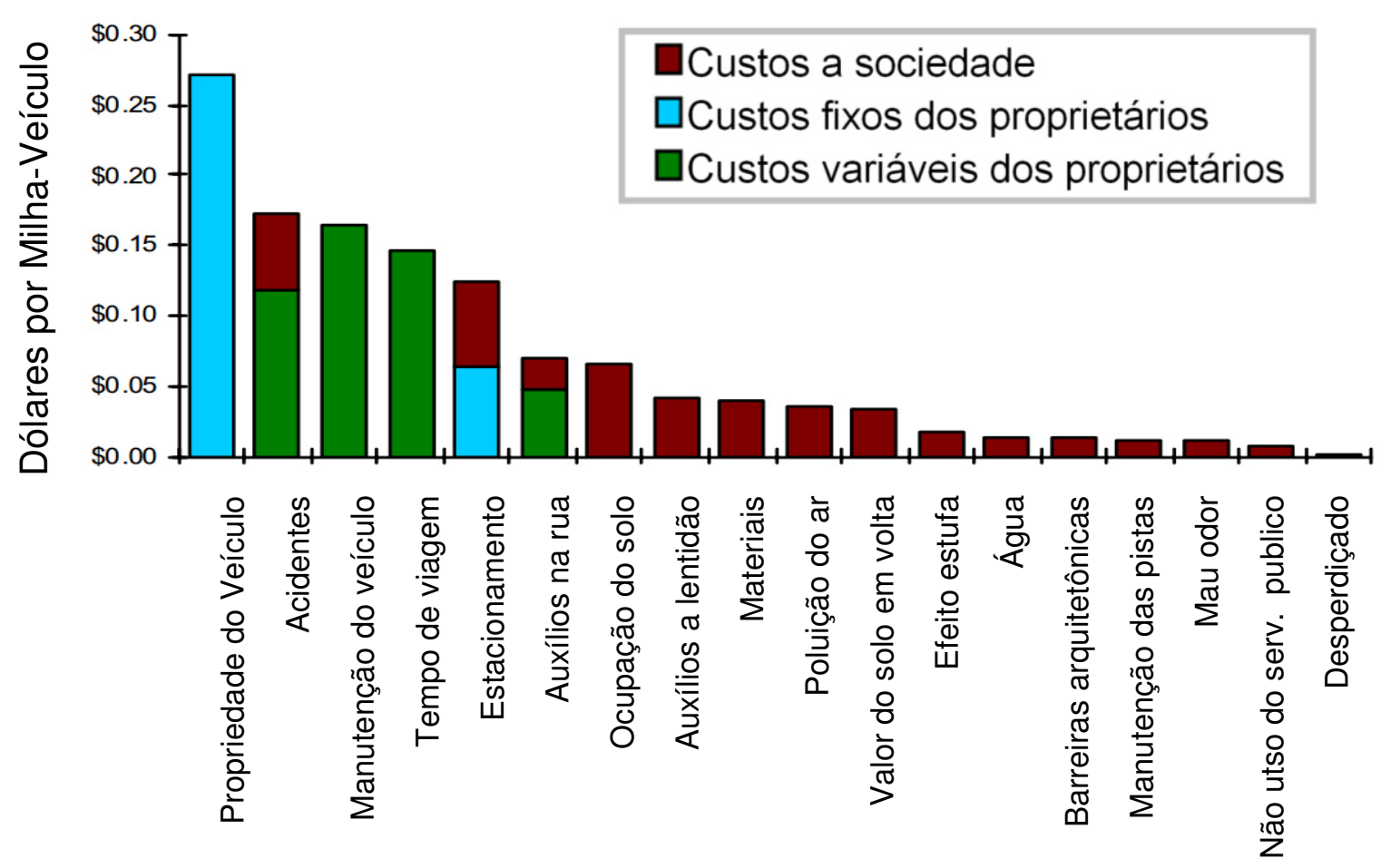

Fonte: Litman; Doherty (2011) 
O mesmo estudo do Victoria Transport Policy Institute relativo à Figura 3 mostra no gráfico de Figura 4 como o uso dos veículos na hora do pico de trânsito corresponde a um gasto duas vezes maior que o normal. A parte vermelha do gráfico indica a contribuição de custo que não é exclusiva dos donos dos veículos, mas de toda a sociedade (custos externos). Este custo no caso do tráfego na hora de pico é muito elevado principalmente por conta dos gastos públicos derivados da poluição do meio ambiente.

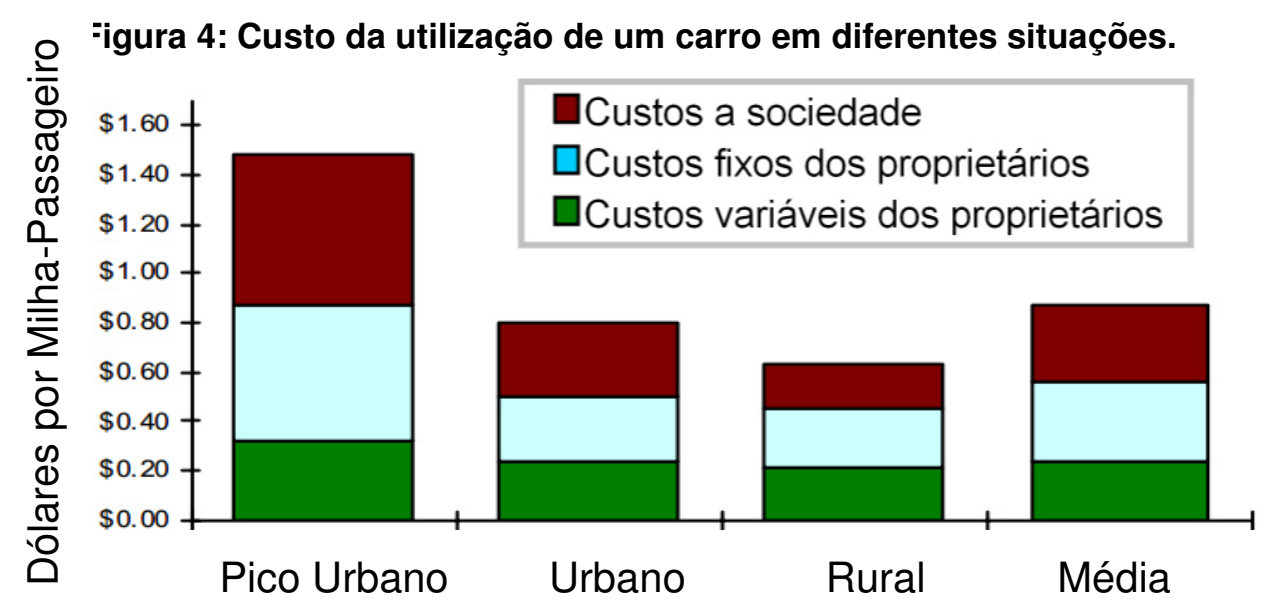

Fonte: Litman; Doherty (2011)

\subsection{Objetivos e Métodos da Literatura da Eng. De Trânsito}

O problema do trânsito começou a ser estudado bem antes do surgimento dos veículos motorizados, chegando já séculos atrás em soluções ainda hoje utilizadas. Os antigos romanos foram o ápice das civilizações antigas, e eles entenderam que um império se baseava nas comunicações entres a suas partes. Assim, construíram uma enorme rede viária que foi utilizada quase sem ajuste por toda Europa até o inicio da época moderna. As estradas romanas eram solidas e bem feitas; a mesma palavra 'estrada' vem da palavra 'estrato' porque elas precisavam de diferentes estratos de materiais, o mesmo principio técnico ainda utilizado. Roma foi a maior cidade do mundo chegando à época imperial a passar de um milhão de indivíduos. Isso significava muita gente nas ruas e muitas mercadorias e comida que chegava e saia das lojas. Em um contexto assim caótico já naquela época houve zonas restritas e por medida de Júlio César os carros de abastecimento das lojas poderiam circular só no período noturno para não atrapalhar o trânsito diário. O problema do 
trânsito foi estudado para outros propósitos no renascimento por conta dos problemas de organização das rotas. Um exemplo foi o problema das sete pontes de Konigsberg resolvido no ano 1736 por Leonhard Euler que aplicou a teoria dos grafos ao problema das rotas. Foi só no século $X X$ com a difusão do carro motorizado a preço baixo, que este problema chegou assumir um caráter global. Já no ano 1935 Greenshields publica um primeiro estudo sobre o trânsito veicular seguido nos anos ' 50 por um grande número de publicações. A partir da segunda metade do século passado até os dias de hoje os estudos trazem uma ampla gama de metodologias para o controle e otimização do trânsito e o projeto das infraestruturas. Os diferentes métodos de enfrentar os problemas em uma rede viária são baseados em modelos que interpretam algum aspecto comportamental constitutivo das dinâmicas do trânsito. Estes modelos se dividem em modelos Macroscópicos, Microscópicos, Mesoscópicos, não sem problemas de classificação, e nos sistemas comerciais podem ser integrados em um sistema Híbrido. $O$ simulador proposto neste trabalho pode ser considerado um quarto nível de simulação para ser integrado nos sistemas híbridos com a finalidade de melhorar a colaboração entre as zonas de tráfego estudadas separadamente utilizando os outros níveis. Sendo uma integração aos sistemas existentes, pode ser utilizado em vários tipos de estudos ligados ao trânsito urbano. No detalhe as aplicações para as quais este trabalho foi pensado são a sincronização de semáforos e dos outros recursos do plano operacional (seções 1.2.2 e 1.2.3).

\subsubsection{Planejamento e dimensionamento de infraestruturas}

O planejamento de uma infraestrutura é fundamental para garantir uma obra funcional no tempo. Os dados iniciais são estudos estatísticos que fornecem valores de trânsito esperado após a abertura da obra e nos decênios seguintes. Nos estudos de planejamento se utilizam modelos Microscópicos no caso de interseções principais e na malha urbana. No caso de planejamento de uma rodovia com muitos quilômetros de comprimento em geral são preferidos os modelos Macroscópicos. Neste tipo de aplicação, em geral é avaliada a funcionalidade de poucas variações da solução, formuladas através da experiência dos engenheiros. Em contrapartida, 
outra vertente para enfrentar problemas de maior dimensão considera o uso de sistemas de otimização encarregados de escolher entre o grande número de soluções a que melhor se ajusta ao caso. (Figuras 5 e 6).

Figura 5: Estudo de viabilidade de duas tipologias de resolução de um cruzamento. Simulador: TSS Aimsun. Estudo para a construção de um retorno no município italiano de Montecosaro.
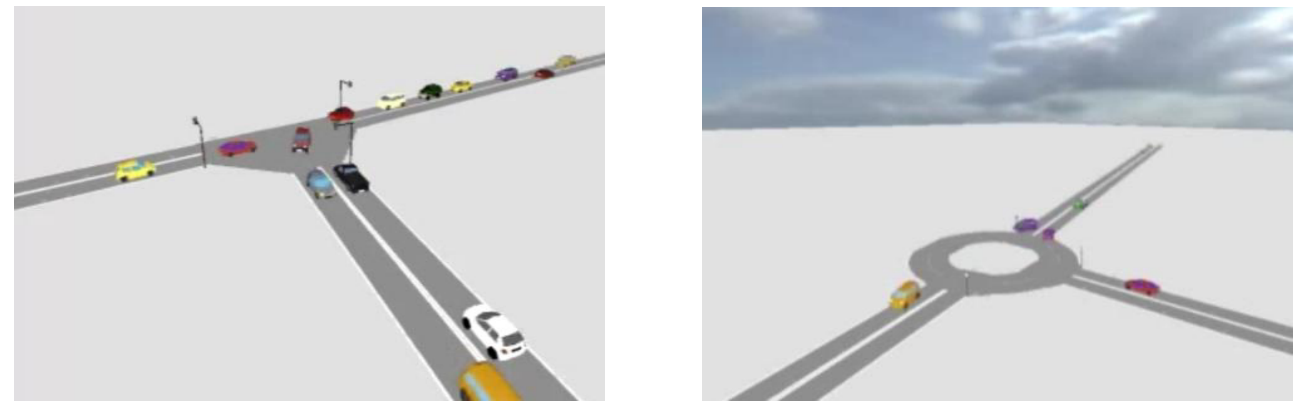

Fonte: Blog ing. Marco de Mitri (2013)

Figura 6: Teste de uma infraestrutura destinada a um trânsito principal; cruzamento entre Rua Buffalotta e viaduto Gronchi em Roma.

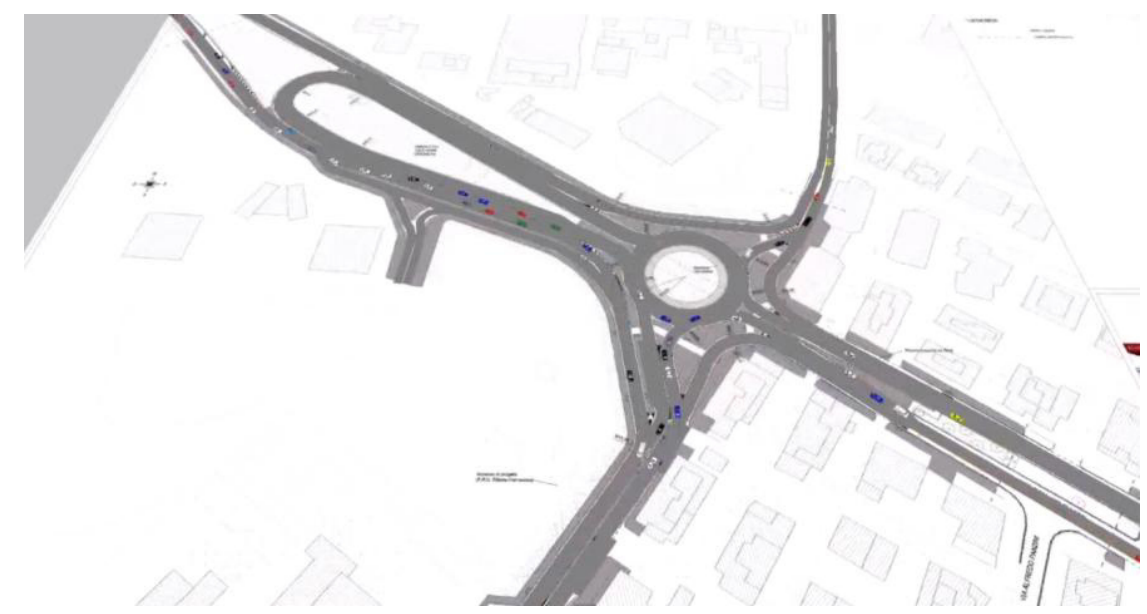

Fonte: Agência Mobilidade Roma

\subsubsection{Sincronização de semáforos}

As redes viárias urbanas são caracterizadas por um grande número de cruzamentos regulamentados através de sinalização como placas de orientação, semáforos e rotatórias. As contínuas interseções dos fluxos de veículos podem ser consideradas a causa principal de formação de filas, e por isso é importante que os semáforos trabalhem conjuntamente gerando, na medida do possível, fenômenos como a 'onda verde'. Neste tipo de aplicação são geralmente usados modelos mesoscópicos acoplados com um algoritmo de otimização; utilizando assim um modelo de tipo 
bottom-up. O processo de otimização precisa executar o modelo iterativamente por milhares de vezes. Os modelos mesoscópicos têm a característica de serem muito rápidos, e assim oferecem um bom resultado em tempos admissíveis. Neste tipo de estudos, mas também em outros de planejamento off-line, faz-se necessário ou desejável construir simuladores dedicados para reduzir a complexidade dos simuladores comerciais, e considerar somente aspectos necessários a cada aplicação específica. A Figura 7 mostra a rede da paulista estudada em Genpolis, dissertação de mestrado apresentada em 2012 na EPUSP, utilizando um simulador mesoscópico construído especificamente para essa aplicação e um método de otimização por algoritmo genético. Como se pode ver a rede tem um comprimento limitado se confrontada a necessidade de uma otimização global da metrópole, mas a experiência direta do colega empenhado no estudo evidenciou a falta de dados abertos necessários para a condução de tal estudo. Nesta situação os dados foram coletados manualmente medindo efetivamente cada fluxo em aproximação aos cruzamentos a cada quinze minutos do horário de pico. Os estudos tipo Genpolis e o novo nível de simulação aqui proposto são diferentes, mas interligados compondo os dois níveis hierárquicos da abordagem proposta. O escopo é o mesmo, o planejamento operacional, mas no primeiro caso os estudos são locais e determinam uma série de planos operacionais localmente ótimos. O novo nível tem a finalidade de encontrar um plano operacional global ótimo combinando os planos locais encontrados pelos estudos locais.

Figura 7: Simulação mesoscópica de uma rede urbana para a sincronização dos semáforos.

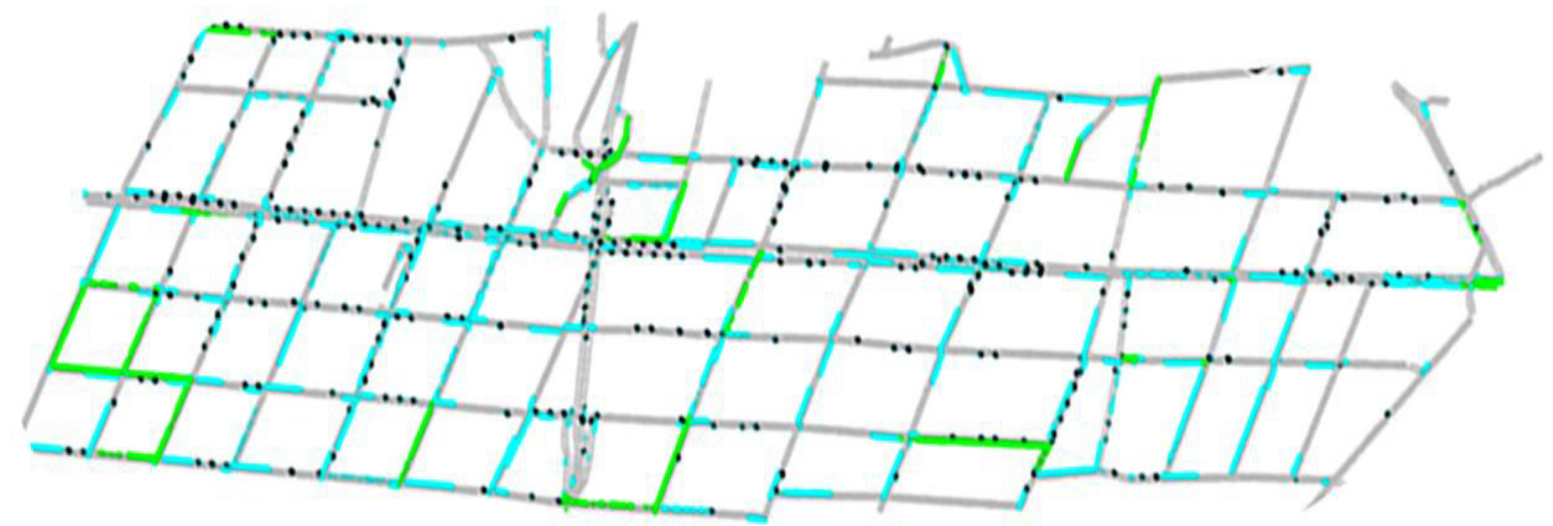

Fonte: Genpolis; EP-USP. Mugnela; Netto (2012) 


\subsubsection{Planejamentos especiais de semáforos e faixas}

Com a ajuda das duas aplicações apresentadas acima as redes viárias são projetadas com base em fluxos médios de veículos. O planejamento em geral è diferenciado nas faixas horárias a fim de acomodar ao máximo as diferenças entre o trânsito matutino e vespertino.

Figura 8: Túnel Presidente Jânio Quadros, São Paulo: flui no sentido Centro [vermelho] entre 04h30min e 09h30min, e muda então de sentido, indo em direção ao Morumbi [amarelo].

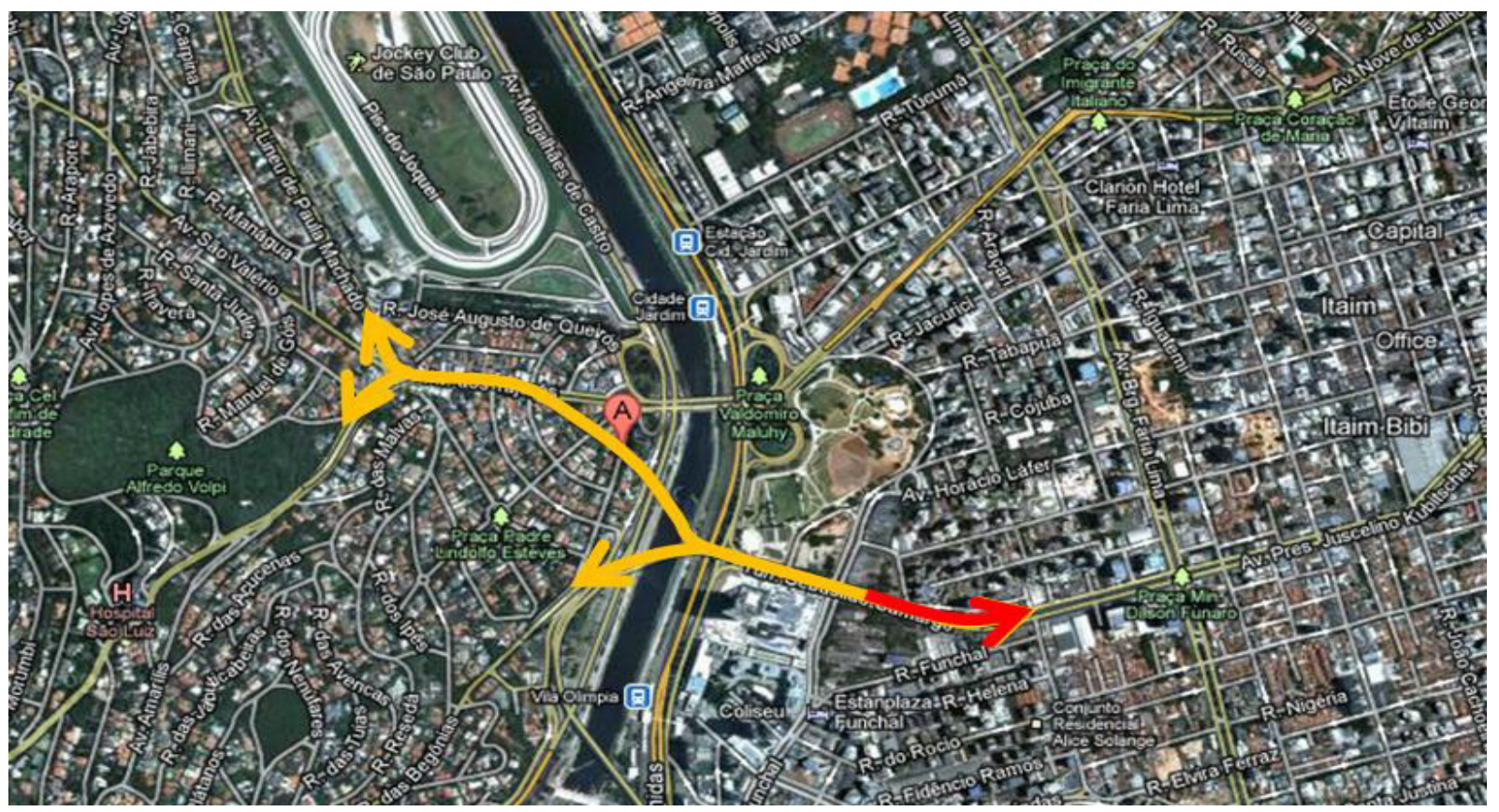

Fonte: Google Maps

No entanto existem muitas condições em que se faz necessário um replanejamento temporário dos semáforos e do uso das faixas. Uma situação típica são ocasiões como feriados ou eventos públicos de grande atratividade, contexto no qual se insere o estudo relativo ao estádio de Itaquera que será utilizado como exemplo aplicativo nesta tese. $O$ simulador proposto pode ser utilizado também na situação de trânsito diário aonde o padrão, como no exemplo dos jogos no estádio de Itaquera, apresente fluxos direcionados intensos. $O$ jeito tradicional de enfrentar um planejamento viário para uma situação especial pode se basear tanto em um processo top-down quanto num bottom-up, sendo que no primeiro caso testa 
simplesmente as propostas utilizando um simulador microscópico ou mesoscópico, enquanto que no segundo caso se utiliza algum algoritmo de otimização parecido com o caso da sincronização de semáforos, e por isso os modelos escolhidos serão de tipo mesoscópico. O escopo é favorecer o fluxo principal de veículos, antes do evento na direção da ida, e depois da volta, mudando temporariamente a temporização dos semáforos e o direcionamento de algumas faixas das pistas. Este tipo de recurso em geral precisa de barreiras móveis para a divisão dos fluxos e um pessoal empregado na movimentação delas comportando assim um custo elevado. $\mathrm{Na}$ cidade de São Paulo existem alguns exemplos desta aplicação em viadutos e túneis gerenciados pela CET (Figura 8).

\subsubsection{Aplicações on-line}

Entre os fenômenos que agem nas dinâmicas dos veículos, é preciso considerar a possibilidade de particulares situações que provocam forte redução da eficiência de alguma infraestrutura ou até mesmo a inoperatividade dela. Esta situação pode derivar de acidentes automobilísticos, forte mal tempo, alagamentos, abertura imprevista de buracos na pavimentação, deslizamento de barro, pedras ou arvores na pista. Devido a impossibilidade de previsão das eventualidades introduzidas existe uma série de métodos para calcular o melhor desvio, fazer previsão acima do acumulo da fila de veículos e otimizar a temporização dos semáforos e faixas para aquele perfil especifico de trânsito. O escopo é permitir um ou mais desvios para os veículos fluírem do jeito mais rápido possível, prever quais outras vias sofrerão alguma consequência, e estimar onde há maior probabilidade de ocorrência de novos acidentes (para colocar placa de advertência, limites de velocidade e veículos médicos e de resgate). Os processos de cálculo são os mesmos dos casos apresentados off-line para o planejamento baseado em dados estatísticos. A diferença é que não tendo conhecimento anterior de como a situação imprevista se apresenta no caso on-line é preciso utilizar alguma ferramenta já pronta, pois ao contrario muitos trabalhos de planejamento off-line requerem a utilização de um simulador especifico. Ao enfrentar um problema on-line em geral os desvios são calculados em áreas limitadas para não atrapalhar outros fluxos principais e reduzir 
o comprimento total do desvio. Podem ser utilizados os três níveis de simulação em acordo com o padrão de transito previsto e a categoria das vias que compõem o caminho de desvio.

\subsubsection{Semáforos inteligentes}

As novas tecnologias além de incorporarem as mais recentes inovações, fazem com que os produtos do setor fiquem mais baratos (Figura 9). Assim, muitos semáforos são ligados a sensores e centrais de gerenciamento que amplificam as possibilidades de prospecção e atuação em tempo real no trânsito.

Figura 9: Aparelhos semafóricos com sensores disponíveis no mercado.

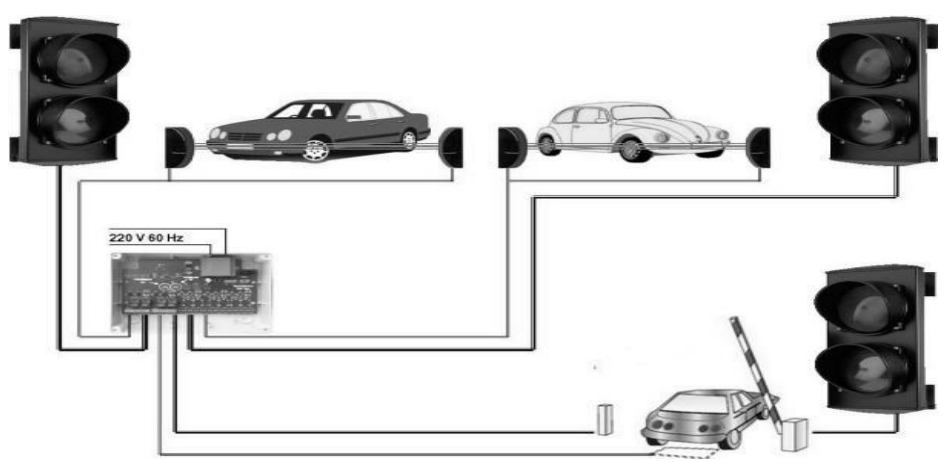

A aplicação de sensores mais básica e que todos conhecemos é para o controle dos semáforos de pedestre ou de pequenas ruas, nos quais o sinal de verde é ativado pela presença de um veículo ou no caso de pedestre apertando o botão no aparelho para indicar sua intenção de atravessar a rua. Nos casos mais interessantes, a maioria dos semáforos de uma área tem sensores medindo o tamanho da fila acumulada. As informações são processadas em tempo real por um algoritmo que gerencia os períodos destes mesmos semáforos. O algoritmo de gerenciamento pode ser baseado em sistemas de autoaprendizagem ou processos periódicos de otimização (Halkias, 1997). Uma possibilidade é o uso conjunto de vários níveis de gerenciamento diferenciando as intervenções em função destes níveis de trânsito. Nestes casos uma central gerencia todos os semáforos mantendo uma visão panorâmica de toda a rede, enquanto que sistemas locais a cada cruzamento intervém para resolver as situações pontuais mais graves. Vários estudos tratam 
também da geração de sistemas a baixo custo, tentando limitar o número de sensores usados. (Pescaru \& Curiac, 2014) (Yousef et al., 2010).

Na cidade de São Paulo o uso dos sensores ainda é limitado e o planejamento das ruas é calculado a partir do trânsito médio em cada faixa horária. Porém os dados instantâneos fornecidos pelos sensores garantem um desempenho melhor que as outras tecnologias baseadas só em dados médios. A partir destas considerações, o desenvolvimento futuro do novo nível de simulação proposto dependerá da possibilidade de se instalar nas vias tecnologias mais avançadas que permitam medidas mais precisas, de modo que melhores aproximações possam ser feitas, para o problema de trânsito, obtendo resultados mais produtivos.

\subsubsection{Aplicações futuras}

Figura 10: Comunicação entre veículos e infraestruturas.

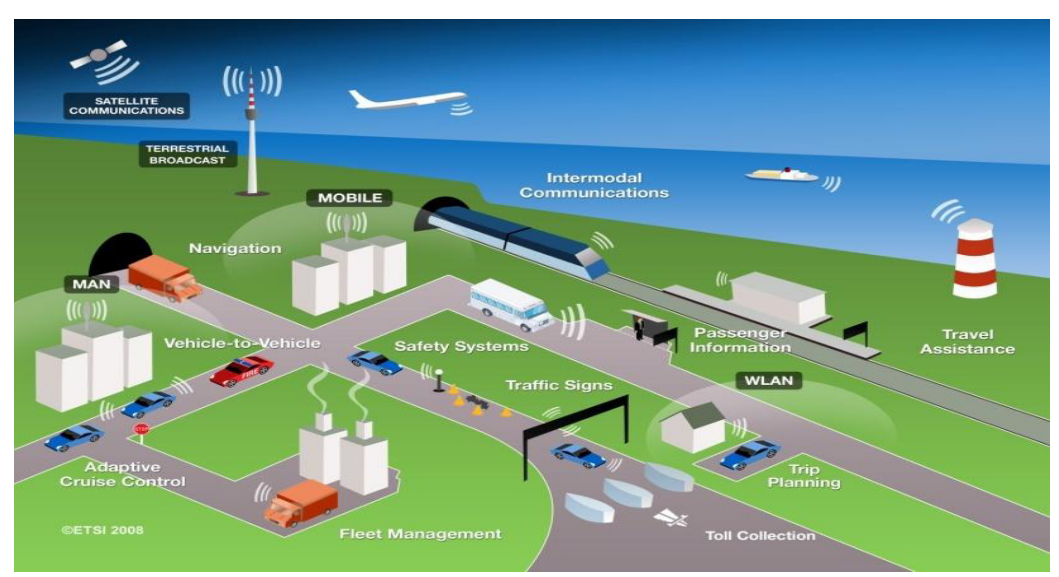

Fonte: Hess (2009)

As aplicações apresentadas até agora são as estratégias mais comuns que foram desenvolvidas e usadas em muitas metrópoles no mundo inteiro. Uma série de aplicações muito mais avançadas está em fase de teste para ser aplicada num futuro próximo. Estas novas técnicas preveem sistemas de comunicação entre veículos, infraestruturas de apoio e os algoritmos de gerenciamento. Assim, uma aplicação funcional precisaria antes ser implantada em toda a infraestrutura, bem como dotar todos os veículos de sistemas comunicantes e de processamento, o que ainda não acontece (o custo ainda é um impeditivo para uma difusão em massa). Os sistemas 
integrados iriam fornecer dados exatos sobre a posição e rota de cada veículo e a situação de trânsito em cada setor de rua da rede viária, com o que os usuários poderiam ser desviados para o percurso mais conveniente naquele momento, recebendo também todas as informações úteis e necessárias para a tomada de tais decisões. Em San Francisco, por exemplo, 8200 vagas de estacionamento nas ruas foram dotadas de sensores magnéticos consultáveis através o site sfpark.org. (http://sfpark.org/)

Figura 11: Sistema de alerta de precedência.

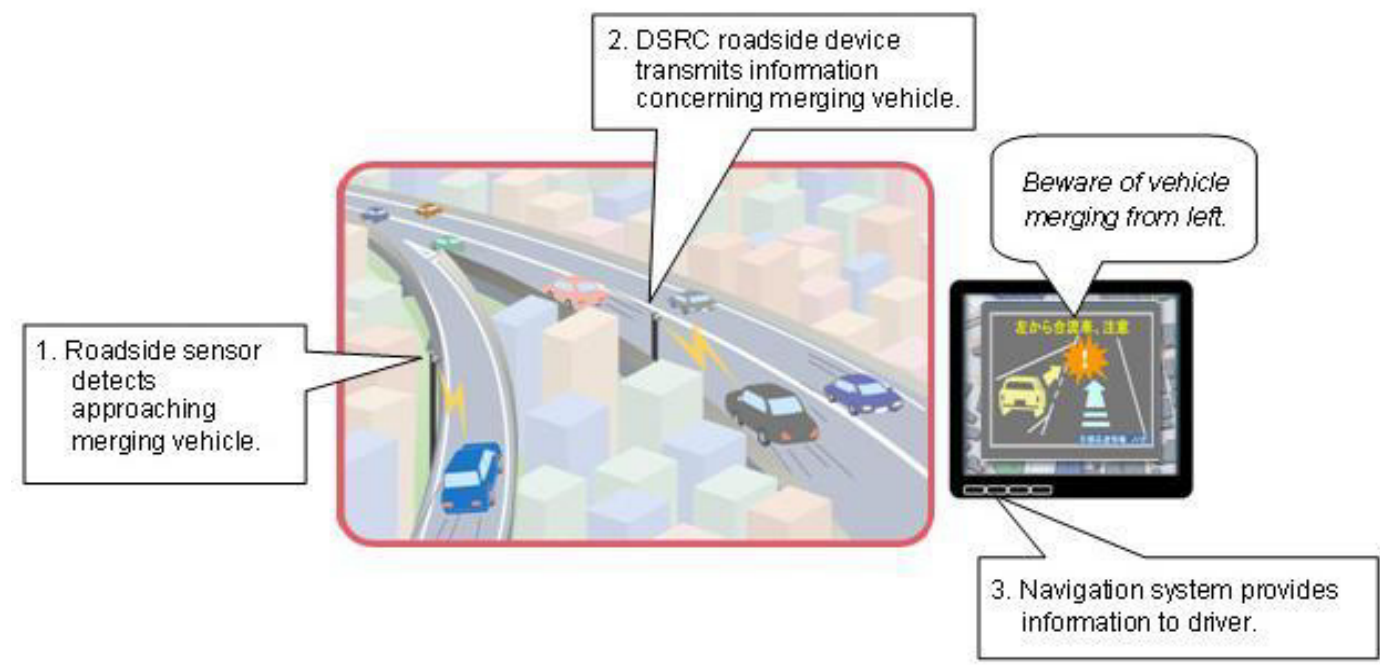

Fonte: Toyota Motor Corporation (2009)

Figura 12: Sistema de alertas por fechamento das faixas e comunicação rápida com os veículos.

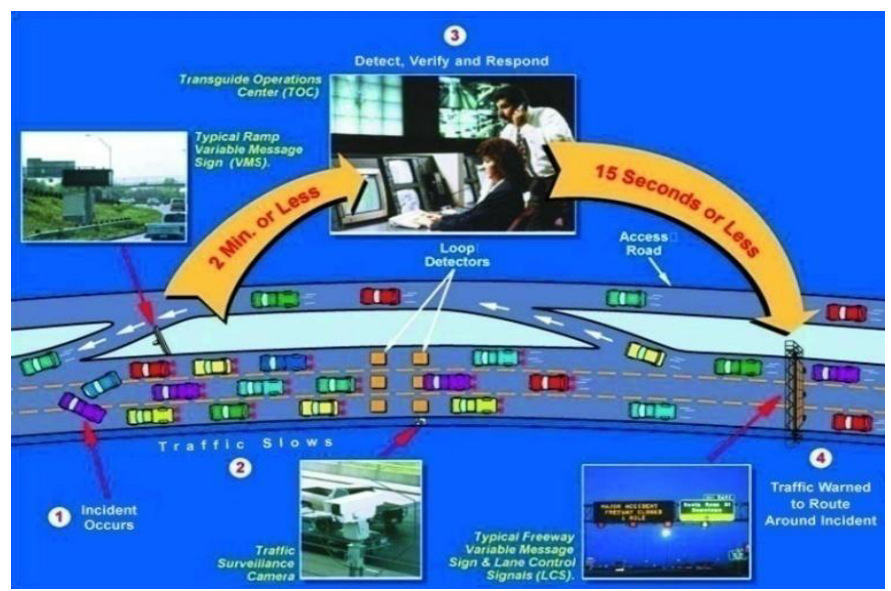

Fonte: SwRI,Southwest Research Institute (2013) 
A disponibilidade da comunicação entre os veículos e as infraestruturas ou diretamente com uma central permite o acumulo automático de dados exatos, de modo que os problemas de obter os dados inicias, como os enfrentados no estudo Genpolis $^{1}$ de 2012, serão melhor resolvidos, tornando os estudos locais mais disponíveis e baseados em dados detalhados.

Nas figuras desta seção pode-se ver alguns cenários propostos. Na Figura 10 temse a representação das possibilidades de comunicação entre infraestruturas e veículos proposto pelo ETSI e universidade de Linkopings (LiU). Já a Figura 11 mostra um sistema de alerta de precedência integrando veículos e a infraestrutura, produzido pela Toyota. A Figura 12 apresenta um exemplo de sistema de alertas de fila por causa de fechamento das faixas que permite informar os veículos em poucos minutos, elaborado pelo Southwest Research Institute (Dellenback, 2013).

${ }^{1} \mathrm{O}$ estudo Genpolis foi apresentado na subseção 1.2.2 


\section{Capítulo 2 - Modelos de Trânsito}

Neste capítulo são introduzidos os resultados históricos da engenharia de tráfego, e apresentada uma classificação dos modelos mais importantes da literatura.

Um modelo físico-matemático é um sistema que interpreta algumas dinâmicas, a partir dos dados fornecidos na entrada e das condições iniciais, para calcular como o sistema real iria evoluir. $\mathrm{Na}$ base de todos os modelos existe uma série de regras que os identificam e que costumam ter o nome de suas leis constitutivas. No âmbito do trânsito a tendência foi identificar leis de comportamentos referidas a dois diferentes sujeitos: no primeiro caso o sujeito é o trânsito na sua totalidade constituindo os modelos denominados Macroscópicos; no segundo caso as leis constitutivas se referem a cada veículo e assim os modelos baseados nesta interpretação são denominados Microscópicos. Em geral os softwares de simulação de trânsito não trabalham com um só nível de descrição, de modo que na literatura se pode encontrar modelos chamados de híbridos, que acoplam modelos micro e macro e talvez meso ${ }^{2}$. Os sistemas híbridos não se referem a um diferente nível de descrição do trânsito, mas são sistemas de integração dos três níveis. Neste contexto o simulador proposto pode ser considerado um quarto nível integrável aos sistemas comerciais.

\subsection{Modelos Macro e Micro}

\subsubsection{Modelo macroscópico}

As leis constitutivas dos modelos macroscópicos provem da visão de que o trânsito possa ser admitido como um fluido com propriedades particulares de compressibilidade. Nestes modelos a condição de trânsito em um ponto da rede viária é identificada através das variáveis contínuas de Densidade e Velocidade, definidas a seguir.

\footnotetext{
${ }^{2}$ As três categorias são apresentadas nas seções 2.1 e 2.2
} 
Densidade: É o número de veículos em um setor de pista dividido pelo comprimento do setor, e assim se mede em número de carros por metro.

$\rho=\rho(x ; t) \quad 0 \leq \rho \leq \rho_{\max } \quad[$ carros $/ \mathrm{m}]$ Densidade de carro no ponto $x$ no instante $t$.

Velocidade: É a velocidade dos veículos naquele ponto e momento.

$v=v(x ; t) \quad 0 \leq v \leq v_{\max } \quad[\mathrm{m} / \mathrm{s}] \quad$ Velocidade do trânsito no ponto $x$ no instante $t$. A primeira lei constitutiva é a função de fluxo que liga velocidade e densidade, ou seja, se admite que a velocidade média dos veículos de um setor de rua depende unicamente da quantidade de veículos presentes.

$v=v_{\max } \cdot f(\rho) \quad 0 \leq f(\rho) \leq 1 \quad$ Velocidade em função da densidade ${ }^{3}[\mathrm{~m} / \mathrm{s}]$.

$f(\rho) \epsilon\left\{C_{0} \mid f(0)=1 ; f\left(\rho_{\max }\right)=0\right\}$

O fluxo é definido como o produto entre velocidade e densidade, sendo medido em número de carros por segundo. Utilizando a eq.1 se recava o fluxo $Q$ em função de f.

$v \cdot \rho=v_{\max } \cdot \rho \cdot f(\rho)=Q(\rho) \quad$ Fluxo dos carros [carros/s]

A segunda lei constitutiva eq. 3 decorre do fato de que a variabilidade no tempo do número de carros em um ponto é igual a diferença entre os veículos que entram e saem naquele instante.

Variabilidade do número de carros no tempo no ponto $(\mathrm{x}, \mathrm{t})$ do domínio espaço temporal ${ }^{4}: \quad \rho_{t} \cdot \mathrm{dt} \cdot \mathrm{dx}$ [carros]

Fluxo em entrada no ponto x no tempo t: $\quad Q(x, t) \cdot d t$ [carros]

Fluxo em saída do ponto $\mathrm{x}$ no tempo $\mathrm{t}: \quad Q(x+d x, t) \cdot d t$ [carros]

$Q(x, t) \cdot d t-Q(x+d x, t) \cdot d t=\rho_{t} \cdot d t \cdot d x$

Dividindo cada termo da eq.3 por $(\mathrm{dt} \cdot \mathrm{dx})$ se tem: $-Q_{x}=\rho_{t} \quad\left[\frac{\text { carros }}{\mathrm{s} \cdot \mathrm{m}}\right]$

Aplicado a primeira lei constitutiva eq:2 e derivando em x se obtém:

\footnotetext{
${ }^{3}$ O pedice com parenteses indica o ponto no qual a funçao é calculada. Ex: $f(\rho)$ ou $f(0)$

${ }^{4} \mathrm{O}$ pedice sem parenteses indica a variavel de derivaçao. Ex: $\rho_{t}$ ou $\rho_{x}$ ou $f_{x}$ ou $f_{\rho}$ ou $Q_{x}$
} 
$-Q_{x}=\rho_{x} \cdot Q(\rho)_{\rho}=-v_{\max }\left(\rho_{x} \cdot f(\rho)+\rho \cdot f_{x}(\rho)\right)=-\boldsymbol{v}_{\max } \cdot \boldsymbol{\rho}_{x}\left(\boldsymbol{f}+\boldsymbol{\rho} \cdot \boldsymbol{f}_{\boldsymbol{\rho}}\right)=\boldsymbol{\rho}_{\boldsymbol{t}}$

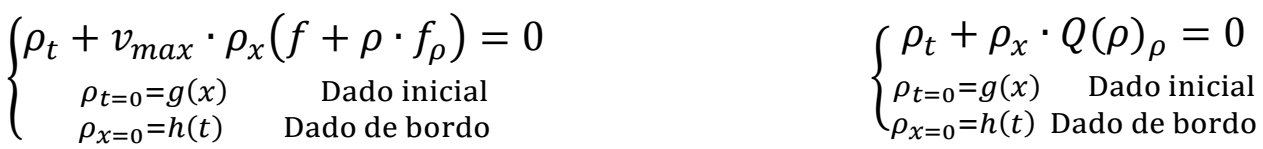

Modelo de setor de rua explicitando $f()$ ou $Q()$. Exemplos de funções $f()$ e $Q()$ propostas na literatura são conteúdos na Quadro 1 da seção 2.2.

Neste caso o sistema tem solução analítica eq.5; o dado inicial $g\left(x_{0}\right)$ fica constante ao longo das curvas $x(t)$. Onde $\mathrm{X}(0)=\mathrm{X}(\mathrm{t}=0)$ é um ponto do domínio espacial, ou seja, a posição inicial de um veículo. E X(t) é a posição do veículo no instante t.

$\left\{\begin{array}{c}\rho(x(t) ; t)=g(x(0)) \\ x(t)=Q_{\rho}(g(x(0))) t+x(0)\end{array}\right.$

(Perna \& Orientador: prof. Sacone, 2008) (Università degli studi di Genova)

\subsubsection{Modelo microscópico}

As leis constitutivas dos modelos microscópicos interpretam o comportamento de um único veículo no meio do trânsito. As variáveis consideradas agora são posição e velocidade de cada veículo na simulação. O principio base é o de ação e reação. Assim, a velocidade de um veículo vai depender da velocidade e posição do veículo que viaja na frente.

$$
\text { efeito }=f(\text { estímulos, percepções })
$$

$\dot{\mathrm{v}}_{\mathrm{t}}=\lambda\left(\mathrm{v}_{(\mathrm{t}-\mathrm{T})}^{\mathrm{p}}-\mathrm{v}_{(\mathrm{t}-\mathrm{T})}\right)$

$\dot{\mathrm{v}}_{\mathrm{t}} \quad$ Aceleração do veículo no instante $t$

$\mathrm{V}_{(\mathrm{t}-\mathrm{T})} \quad$ Velocidade do veículo no instante $t-T$

$\mathrm{v}^{\mathrm{p}}(\mathrm{t}-\mathrm{T}) \quad$ Velocidade do veículo que precede no instante $t-T$

$T \quad$ Parâmetro tempo de reação

$\lambda \quad$ Parâmetro de sensibilidade

$\mathrm{Na}$ formulação mais simples como na eq. 6 a aceleração de cada veículo depende da diferença entre a própria velocidade e a do veículo que o precede, com um fator 
multiplicativo chamado de parâmetro de sensibilidade. O parâmetro de sensibilidade $\lambda$ precisa ser calibrado e depende do tipo de veículo simulado. Um carro terá um valor $\lambda$ mais alto que o de uma caminhonete, que sendo muito pesada tem como característica uma aceleração e frenagem mais lentas. Este modelo, assim como descrito na eq.6, pode ser utilizado somente em situações tipo ponte ou túnel aonde não haja entrada e saída de veículos nem possibilidade de ultrapassagem. Para permitir as manobras de troca de faixas para a ultrapassagem, entrada e saída de veículos, intervenção da ação de semáforos ou veículos de emergência ou qualquer estimulo que um motorista receba do seu redor, que influencie a sua forma de condução, é necessário implementar cada manobra separadamente. (Perna; Sacone, 2008)

\subsubsection{Desempenho dos modelos}

Quadro 1 : Modelos de simulação

\begin{tabular}{|c|c|c|c|c|c|}
\hline Nome modelo & Autor & Classificação & $\begin{array}{l}\text { Grau da } \\
\text { equação }\end{array}$ & $\begin{array}{l}\text { Continuo } \\
\text { Discreto }\end{array}$ & Ano \\
\hline LWR & Lighthill-Whitham-Richard & Macro & 1 grau & $\mathrm{C}$ & 1955 \\
\hline Boltzmann-like 1 & Prigogine & Macro & 2 grau & $\mathrm{C}$ & 1960 \\
\hline Boltzmann-like 2 & Phillips & Macro & 2 grau & $\mathrm{C}$ & 1979 \\
\hline LWR generalizado 1 & Whitham & Macro & 2 grau & $\mathrm{C}$ & 1984 \\
\hline LWR generalizado 2 & Kerner e Konh & Macro & 2 grau & C & 1993 \\
\hline CTM & Daganzo & Macro & 1 grau & $\mathrm{D}$ & 1994 \\
\hline LWR discreto & Weidlich-Hilliges & Macro & 2 grau & $\mathrm{D}$ & 1995 \\
\hline Car Following & Reuschel-Pipes & Micro & 2 grau & $\mathrm{C} / \mathrm{D}$ & 1958 \\
\hline Lane Change & P. Gipps & \multirow{4}{*}{\multicolumn{3}{|c|}{$\begin{array}{l}\text { Estes modelos são auxiliares do Car } \\
\text { Following e permitem a troca de faixa dos } \\
\text { veículos. }\end{array}$}} & 1986 \\
\hline Gap Acceptance & Herman e Weiss, & & & & 1981 \\
\hline Gap Acceptance & Daganzo & & & & 1981 \\
\hline Gap Acceptance & Kita & & & & 1993 \\
\hline Cellular Automation & Nagel & Micro & 1 grau & $\mathrm{D}$ & 1992 \\
\hline
\end{tabular}

Fonte: Galli (2010) e Perna; Sacone (2008) e Martins et. al. (2013) e Deganzo (1993)

A história moderna do estudo de problemas do trânsito se inicia na segunda metade do século XX com a difusão nas cidades dos veículos particulares. A tecnologia da computação deu novo poder às aproximações analíticas que através da matemática numérica puderam ser estudadas também nos casos onde só a avaliação manual 
não conseguia fornecer resultados. O simulador macroscópico derivado das equações dos fluidos ao longo das décadas foi proposto em muitas formas de primeiro e segundo grau, definindo sempre mais detalhes que permitem, por exemplo, a introdução de frota de veículos diferenciados e interseções com ou sem semáforos. Através do modelo LWR já se pode apreciar os fenômenos da onda de rarefação na fronte de carros em partida na abertura de um semáforo, ou a onda de choque que se propaga na direção contrária ao sentido a ser percorrido em situações de fechamento da pista. Nos modelos sucessivos foram introduzidas outras dinâmicas como a probabilidade de colisão e o termo de difusão para permitir a ultrapassagem. Como exposto na introdução os modelos macroscópicos são utilizados principalmente nas rodovias ou avenidas de grande porte porque conseguem tratar muitos veículos e longos trechos com um baixo custo computacional. Porém os modelos macroscópicos não conseguem capturar algumas dinâmicas típicas da condição de tráfego intenso com velocidade baixas. A calibração do simulador através a escolha da função $f(\rho)$ (1) faz com que, mesmo o modelo não percebendo as oscilações de velocidade causadas pelas dinâmicas menores, a velocidade média é exata. Isso significa que por trechos longos é possível calcular o tempo de viagem sem grandes erros fazendo dos modelos macroscópicos, sendo assim os aconselhados para estas situações. Nas situações onde a presença de semáforos quebra as dinâmicas frequentemente, as pequenas oscilações não consideradas pelos modelos macroscópicos se somam gerando erros perceptíveis. Com palavras da engenharia se pode falar que o modelo macroscópico tem um erro de borda ${ }^{5}$ devido a não visualização dos carros, e cada cruzamento representa uma borda de inicio ou fim dos trechos. Nas situações nas quais os cruzamentos determinam de jeito preponderante as dinâmicas do trânsito é preciso utilizar modelos que colocam o foco no veículo, como os modelos microscópicos ou mesoscópicos derivados do Car-Following. Estes modelos permitem representar situações que chegam a uma estabilidade em condições de trânsito leve, mas em condições de tráfego médio ou intenso a estabilidade se perde sendo introduzidos efeitos periódicos típicos das dinâmicas reais. Estes fenômenos periódicos são conhecidos como stop and go e de trânsito 'efeito minhoca'. Os modelos mesoscópicos se colocam em situação intermediária utilizando a equação

\footnotetext{
${ }^{5}$ Em engenharia muitos modelos apresentam o cálculo exato no interior do domínio mas geram erros nas bordas por causa das simplificações na região de fronteira.
} 
macroscópica para a primeira parte dos trechos de rua e a micro para corrigir o erro nas regiões de borda nas quais os veículos fazem as manobras de dar partida e de parada antes do cruzamento. (Mugnela; Netto, 2012) (Perna; Sacone, 2008) (Galli, 2010)

\subsection{Modelos Mesoscópicos}

A última classe de modelos que surgiram foram os modelos mesoscópicos (Quadro 2), uma visão intermediária entre os macros e os micros, e que aspiram usufruir dos benefícios destas duas categorias. A visão mesoscópica põe a própria atenção em objetos intermediários entre o trânsito na sua complexidade e os veículos nas suas unicidades, e assim em geral o sujeito da descrição do modelo são pacotes de veículos próximos, com um estilo descritivo de tipo agregado. A ideia é que no interior de cada pacote os veículos serão sujeitos às mesmas condições. Os pacotes são gerenciados através de um sistema parecido com aqueles dos modelos macroscópicos, permitindo assim calcular bem as ondas de rarefação e de impacto, com a intervenção de processos de tipo micro para melhorar os cálculos em proximidade dos semáforos. As características dos modelos mesoscópicos fazem com que eles mantenham uma descrição bastante detalhadas em comparação aos modelos macroscópicos e também resultam computacionalmente muito mais leves que os modelos microscópicos. (Mugnela; Netto, 2012) (Burghout, 2004)

Quadro 2 : Modelos Mesoscópicos.

\begin{tabular}{|l|l|l|l|}
\hline CONTRAM & Leonard, D.R. & Meso & 1989 \\
\hline DYNAMIT & Ben-Akiva, M. & Meso & 1996 \\
\hline DYNASMART & Jayakrishnan, R. & Meso & 1994 \\
\hline FASTLANE & Gawron, C. & Meso & 1998 \\
\hline DTASQ & Mahut, M. & Meso & 2001 \\
\hline
\end{tabular}

Fonte: Perna; Sacone (2008)

\subsection{Diagrama Fundamental}

Neste parágrafo é apresentado um instrumento muito útil no estudo do trânsito, o diagrama fundamental (Figura 13), um diagrama cartesiano com a densidade de 
veículos na abscissa e o fluxo na ordenada. Este diagrama pode ser traçado a partir de todos os modelos e ser comparado com o traçado a partir da observação das ruas. Nos modelos microscópicos se pode traçar o gráfico efetuando uma simulação, mas nos macroscópicos o fluxo é determinado pela função $Q(\rho)$, de modo que o diagrama traçado para este último tipo é determinado a priori. O gráfico apresenta uma primeira fase de crescimento do fluxo em correspondência ao crescimento da densidade, seguida por outra de decréscimo causada pela queda da velocidade com a progressiva saturação das vias.

Figura 13: Forma qualitativa do diagrama fundamental do trânsito repartido nas zonas de trânsito livre, com fenômeno de stop and go, trânsito a minhoca, parado.

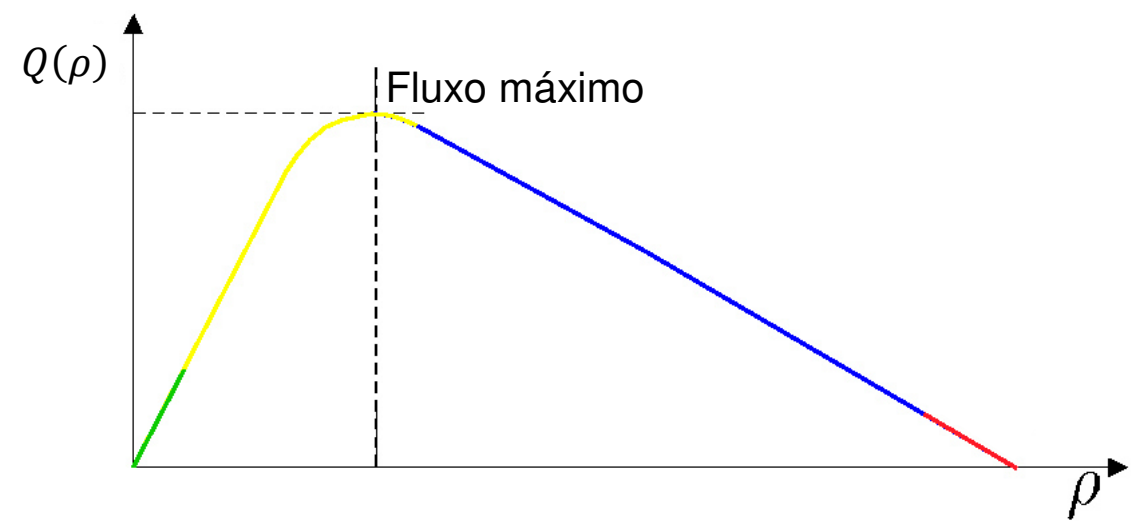

Fonte: Rossa; Tomarelli (2008)

O primeiro trecho corresponde a condição de estrada livre onde a velocidade se mantém na máxima permitida (verde). A segunda parte indica um andamento que já apresenta algum fenômeno de stop and go, a velocidade média diminui mas o aumento da densidade faz que o fluxo ainda suba até a saturação (amarelo). A terceira parte indica a fase de trânsito com um andamento dos veículos típicos do efeito minhoca com pausas de paradas sempre mais longas com o crescer da densidade (azul). A ultima parte indica a situação de lentidão, a velocidade é quase zero e a densidade chega ao máximo (vermelho). Na Figura 14 e Quadro 3 se pode ver um confronto entre os gráficos recavados por simuladores microscópicos e os utilizados nos simuladores macroscópicos. Em detalhe os grafos de Figura 14 foram recavados dos modelos car following continuo com sensibilidade fixa, sensibilidade dependente do espaço livre na frente e sensibilidade dependente da velocidade do veículo; o quarto è o diagrama do modelo de Nagel. Na Quadro 3 são as principais funções $f(\rho)$ e relativas $Q(\rho)$ propostas na leteratura dos modelos macroscópicos. 
Figura 14: Diagramas fundamentais do trânsito recavados por simuladores microscópicos. Todos os graficos representam o fluxo ao variar da densidade de veículos.
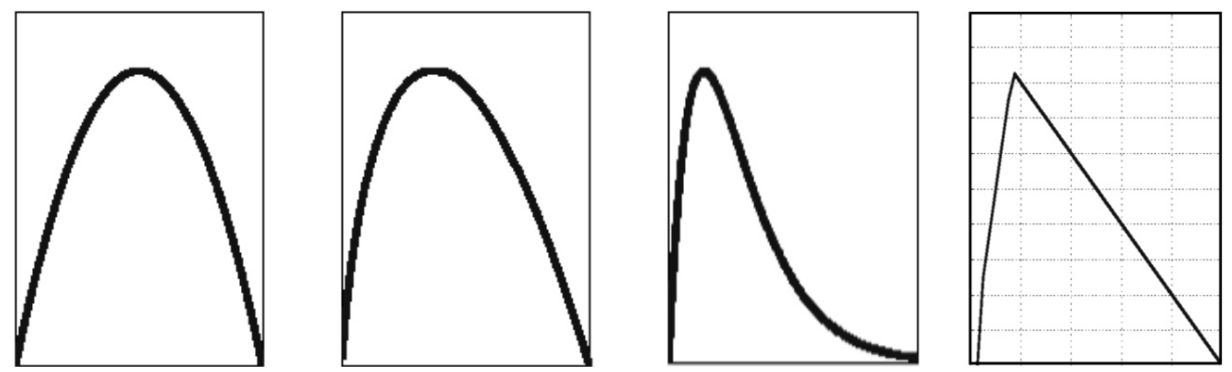

Fonte: Rossa; Tomarelli (2008)

Quadro 3 : Diagramas fundamentais do trânsito recavados por simuladores macroscópicos. Todos os exemplos representam a velocidade dos veículos ao variar da densidade e o relativo fluxo de veículos também em função da densidade.

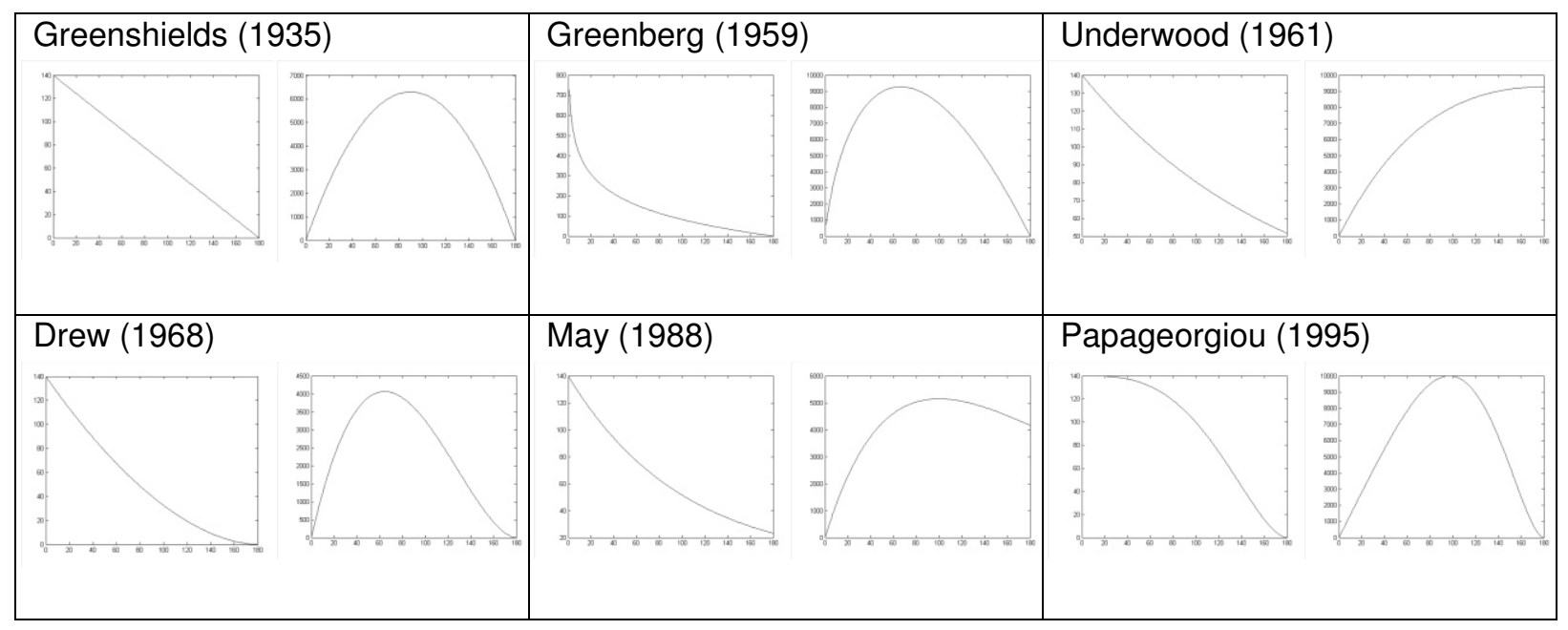

Fonte: Universidade de Genova <www.dist.unige.it/ccontheweb/curriculum/MyPoster.pdf>

\subsection{Modelo Cano-Esponja}

É dedicada uma seção especial para este modelo porque ele apresenta uma característica que será comum e inspiradora para o modelo proposto neste trabalho. O caráter particular deste modelo é a agregação de algumas estruturas viárias em algo que modela o comportamento interno a uma região (área). Em todos os outros modelos apresentados a rede viária nunca resulta alterada e só nos casos mesoscópico e macroscópico os veículos ficam agregados em entidades conceituais que não pertenciam a realidade, mas que modelam parte dela. (Della Rossa; Tomarelli, 2008) (Quarteroni, 2010) 
Figura 15: Gráfico dos canos na região do Veneto no norte da Itália.
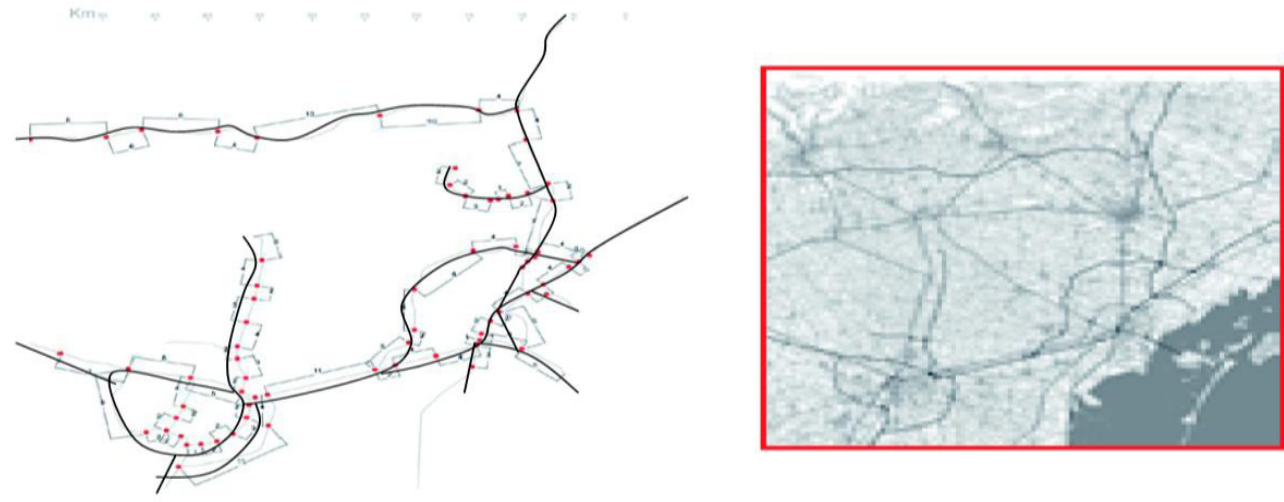

Fonte: Della Rossa; Tomarelli (2008)

Figura 16: Infraestruturas isolantes classificadas como cano.

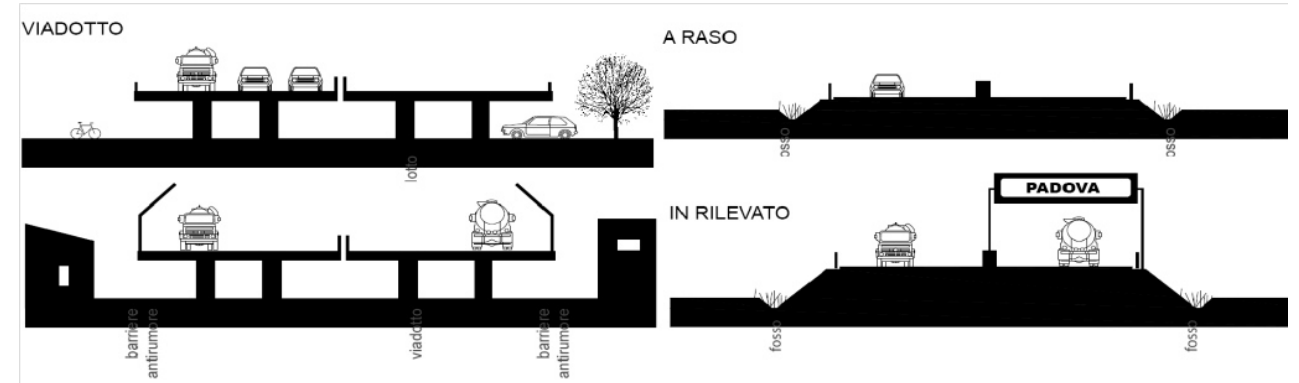

Fonte: Della Rossa; Tomarelli (2008)

Figura 17: Infraestruturas porosas classificadas como esponja.
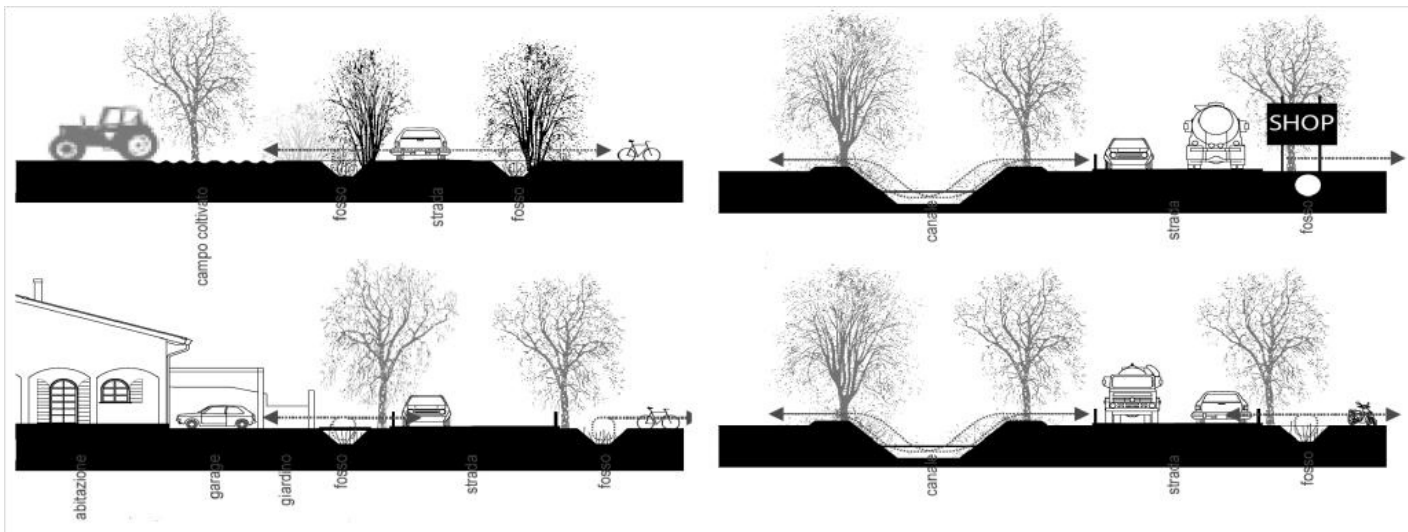

Fonte: Della Rossa; Tomarelli (2008)

O modelo de cano e espoja se baseia numa visão sociológica da rede viária que não é somente algo que permita o movimento dos veículos, sendo também uma interface entre motorista e ambiente. A interface pode ser de dois tipos:

i) Interface fechada que não permite ao motorista perceber o ambiente ao redor, e permite a entrada e saída somente por meio de acessos exclusivos (rampas ou similares) sem permitir paradas intermediárias (Figura 15); 
ii) Interface aberta que permite perceber o ambiente e assim tem pontos de chegada em todo a sua extensão, como casas, lojas e assim por diante.

A divisão adotada neste modelo atribui a categorias dos canos as vias com interface fechada (Figura 16); enquanto as esponjas representam as interfaces livres (Figura 17). (Della Rossa; Tomarelli, 2008)

Figura 18: Permeabilidade e porosidade de dois tecidos reais.

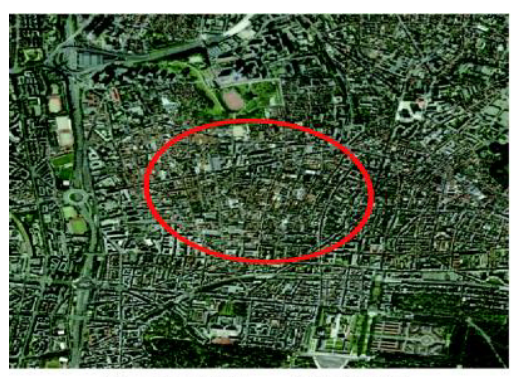

Porosità $=16.9 \%$

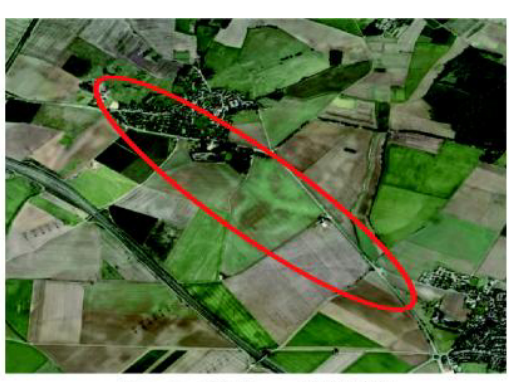

Porosità $=3.2 \%$

\section{Fonte: Della Rossa; Tomarelli (2008)}

Figura 19: Permeabilidade de dois tecidos-teste representadas por os dois autovetores de comprimento proporcional aos autovalores.
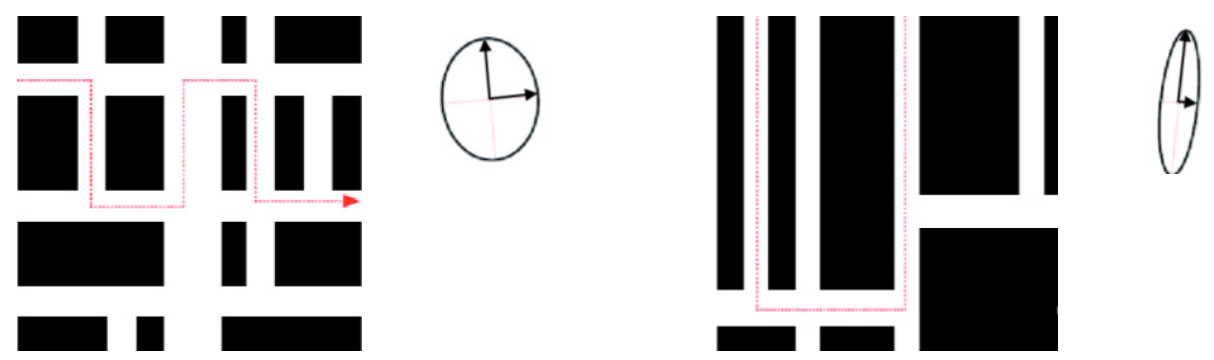

Fonte: Della Rossa; Tomarelli (2008)

Os canos são infraestruturas principais nas quais o trânsito é interpretado por um modelo de tipo macroscópico que assim permite com um baixo custo computacional o gerenciamento de um grande número de veículos em uma rede, composta de setores de grande comprimento, conectando as zonas de um território extenso (ex: Grande São Paulo) (visitesaopaulo.com). As zonas internas à rede de canos segue uma equação dos fluidos típica dos meios esponjosos, dependente de dois parâmetros, um numérico a porosidade, e um vetorial a permeabilidade direcional (Figuras 18 e 19).

Porosidade: O valor numérico é a porosidade da esponja definida como a percentagem de superfície pavimentada para o trânsito no total da área considerada. 
Permeabilidade: O valor vetorial é a permeabilidade definida em cada direção, ela é representada por uma matriz na qual os dois autovetores indicam as direções de máxima e mínima permeabilidade.

\subsubsection{Composição do modelo}

As zonas que são consideradas esponjas serão divididas em polígonos que serão considerados como um único elemento, agregando a dinâmica de todas as vias internas em uma equação macroscópica. O modelo completo será assim constituído por uma série de equações diferenciais comunicantes pelos dados das condições de contorno. Como resultado da escolha inicial de divisão segundo o tipo de interface que as infraestruturas apresentam, a fronteira dos domínios que pertenciam às esponjas é continua e a comunicação com o redor é livre em cada ponto dela. Ao contrário, os canos deixam os fluxos entrar e sair só em poucos pontos isolados, de modo que o dado de borda será pontual para cada acesso (entrada e saída). Os dados de borda das esponjas serão assim para cada lado dos polígonos uma função dependente seja do tempo seja da posição no lado $f(x, t)$. Nos canos para cada ponto de saída/entrada de fluxo é necessária uma função dependente só do tempo $f(t)$, uma vez que a posição já está determinada (associada ao ponto de entrada ou saída em questão). As fronteiras que ficam no perímetro externo do mapa têm dados conhecidos. Por outro lado, as fronteiras entre dois elementos internos ao mapa terão o mesmo dado nos dois lados, conectando em um sistema as equações dos diferentes elementos. (Della Rossa \& Orientador: prof. Tomarelli, 2008)

\subsubsection{Projeto "Grand Paris"}

O estudo de trânsito de Paris com o modelo de cano e esponjas foi lançado em 2008 pelo governo francês ${ }^{6}$ com o intento de estudar e avaliar as condições de trânsito da capital e assim ter uma base para o projeto de novas infraestruturas. A resposta foi

${ }^{6}$ Apresentação do projeto pelo governo francês: http://www.territoires.gouv.fr/spip.php?article3540 
encontrada com o uso deste modelo que permite a modelagem de zonas muito grandes (Figura 20). O estudo é mesmo parte de um amplo projeto de renovação dos sistemas de transporte da capital francesa com prazo ate 2030. O projeto é previsto para atender as quatro necessidades que terão resposta ao longo deste prazo.

1. Melhorar o serviço oferecido ao viajante por meio de uma melhoria real da comodidade dos meios de transporte e uma reorganização das informações para o viajante (ate 2017).

2. Renovação e ampliação da rede; referido a ônibus, bonde e metro (ate 2017).

3. Construção de linhas de integração, conectando quinze estações de metro existentes (ate 2030).

4. A criação da ligação direta para o aeroporto Charles de Gaulle (para definir).

Figura 20: Mapa do território considerado no estudo da viabilidade do projeto Gran Paris.

Fonte: Quarteroni (2010) 


\section{Capítulo 3 - Processos de Otimização}

Os processos de otimização consistem de técnicas para aperfeiçoar uma solução. Isso significa que a utilização destas técnicas é reservada a problemas para os quais existe um algoritmo de geração de soluções, sem todavia ser possível prever seu custo efetivo. Assim, tais processos não se propõem a resolver o problema propriamente dito, mas a encontrar algumas soluções que tenham um custo total mínimo.

Estas técnicas tem alguns elementos fundamentais em comum:

1. Função de otimização, que serve para avaliar a qualidade das soluções encontradas, sendo a melhor solução representada pelo máximo ou mínimo desta função.

2. Vínculos, que indicam os limites entre os quais as soluções podem ser aceitas, ou seja, interpretam quais características devem ter as soluções do problema.

Exemplo: Num projeto de linhas elétricas é necessário encontrar o caminho mais curto que une uma série de pontos (usinas e cidades ou vilas).

Pode-se notar que a solução do problema é banal, bastando cuidar para que todos os pontos sejam conectados, mas talvez uma topologia feita manualmente gaste muito mais recursos do que o necessário. O propósito do processo de otimização é mesmo garantir que a solução obtida seja uma qualitativamente "boa" no espectro de valores determinados pela função de otimização. No caso do exemplo proposto, a função de otimização é o comprimento total da rede elétrica, ou seja, a soma das ligações planejadas, e em geral é um modelo dos gastos ligados a construção da obra. O ótimo é representado pelo ponto de mínimo da função, ou seja, pelo menor caminho ligando todos os pontos. O vínculo considerado é um só, e descreve o fato de que, para ser solução, todos os pontos precisam ser conectados. 


\subsection{Processos Exatos}

Existe uma série de algoritmos exatos ${ }^{7}$ para otimizar todas as tipologias de problemas existentes. Porém, estes métodos, em muitas situações, não podem ser usados porque envolvem tempos computacionais não aceitáveis. A classe de problemas que mais se presta para a resolução exata é constituída dos problemas que podem ser descritos através da programação linear (LP), otimizados posteriormente com o algoritmo de Simplex. Mesmo assim, se as instancias são em grande número, torna-se necessário utilizar algum algoritmo heurístico que pode também ser acoplado à descrição da LP.

\subsection{Problemas NP Completos}

A classe de problemas NP completos (não deterministicamente polinomiais) é constituída de problemas todos da mesma dificuldade computacional, que por quanto conhecemos até agora, é determinado pelo fator de crescimento do número de soluções, função de ordem combinatória do tamanho da instância. Todos estes problemas são redutíveis uns aos outros por meio de algoritmos conhecidos de custo polinomial com o tamanho da instância. Isso os interliga de modo que encontrando um algoritmo polinomial, capaz de resolver o problema do ótimo em qualquer um deles, todos eles se tornariam solucionáveis em tempo polinomial. $\mathrm{O}$ fato que ninguém nunca encontrou tal algoritmo e que a resolução de um seria também a resolução de todos deixa as comunidades científicas de hoje convencidas que não existe uma solução de custo computacional polinomial mesmo não existindo alguma demonstração disso. Típicos problemas da classe NP completa ligados ao trânsito são o Travelling Salesman Problem e o Vehicle Routing Problem. (Cook, 2000)

\footnotetext{
${ }^{7}$ Processos exatos: termo usado em pesquisa operacional para definir os processos que chegam sempre a solução ótima.
} 


\subsection{Processos Monótonos Crescentes}

A partir de agora por simplicidade será considerado o caso em que a solução ótima corresponde ao valor máximo da função de otimização. Esta consideração não traz nenhuma perda de generalidade sendo que o mínimo de uma função corresponde a ao máximo do inverso desta mesma função.

Os métodos heurísticos de pesquisa partem de uma ou mais soluções para depois gerar alternativas calculadas a partir das primeiras até chegar a uma solução satisfatória. Esta em geral não é a melhor possível porque para favorecer a velocidade da computação, em problemas da classe NP, os métodos heurísticos testam só uma pequena porção do domínio deixando de ser métodos exatos. Uma primeira tipologia de algoritmos tenta encontrar soluções sempre melhores através de modificações básicas da solução corrente. Estes métodos podem ter um ou mais pontos de partida para melhorar a probabilidade de encontrar soluções boas. Todos eles convergem em tempos curtos em um ou uma série de máximos locais da função sem poder continuar a pesquisa (Figura 21). Entres os mais conhecidos temse os métodos Hill Climbing e Random Multistart. (Monticone; Amaldi, 2008) (De Giovanni, 2008)

Figura 21: Exemplo de percurso de busca típico do algoritmo Hill Climbing.

The problem with hill climbing is that it gets stuck on "local-maxima"

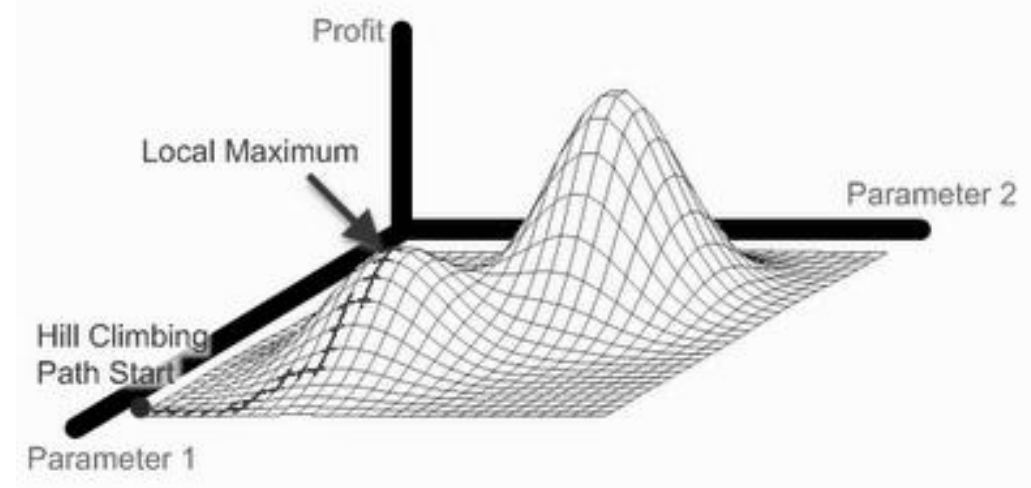

Fonte: Galdino (2010) 


\subsection{Pesquisa Tabu}

Imaginando a superfície da função de otimização como uma paisagem que precisa ser descoberta, parece claro que nem sempre é possível chegar ao ponto mais elevado da região através um caminho de só subida. Esta ideia leva a desenvolver processos capazes de explorar a região de jeito continuo, aceitando também algum movimento pejorativo para fugir dos máximos locais (Figura 22). (De Giovanni, 2008) (Monticone; Amaldi, 2008)

Figura 22: Típico andamento do processo de pesquisa por algoritmo Tabu. As áreas mais escuras indicam as regiões com valores "melhores". 0 ponto vermelho indica o ótimo global.

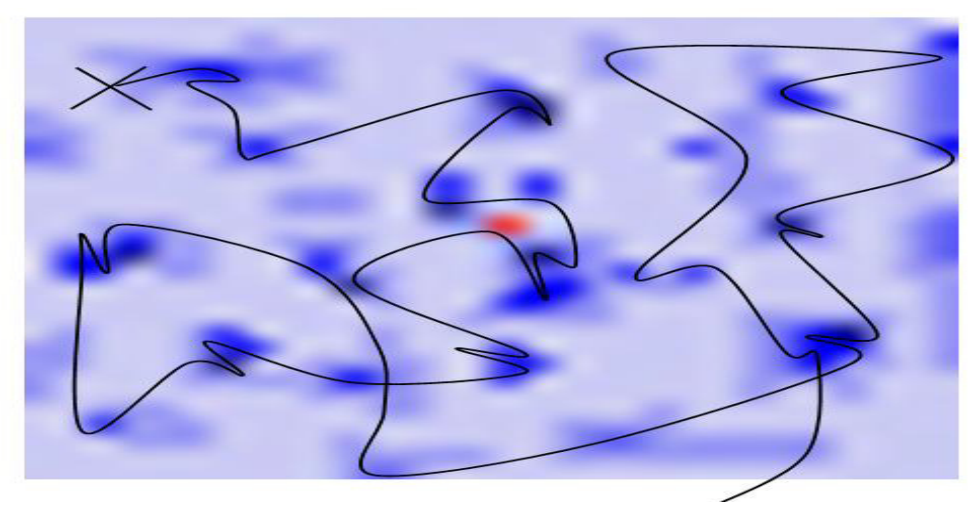

Fonte: Monticone; Amaldi (2008)

\subsubsection{Problema dos ciclos}

Neste tipo de algoritmo é preciso colocar alguns recursos específicos para sair da condição de ciclo. Podemos pensar, como exemplo, em um programa de pesquisa que, chegando a um máximo local, inicia aceitando novas soluções um pouco piores se afastando dele (Figuras 23 e 24). Se através destas modificações pejorativas não se consegue sair da bacia de atração do mínimo, os movimentos a seguir voltarão na direção de soluções já avaliadas entrando com boa probabilidade em um ciclo. Em geral os recursos contra os ciclos são de dois tipos:

1. Uma pequena memória das transições que evita explicitamente os ciclos cujo tamanho não seja grande demais. Em geral na pesquisa tabu esta sequência 
não supera as dez ultimas modificações. (De Giovanni, 2008) (Monticone; Amaldi, 2008)

2. Os ciclos maiores acontecem com probabilidade menor, de modo que em geral não vale a pena gastar memória para lembrar explicitamente a sequência dos movimentos. Uma técnica utilizada é a introdução de algum efeito aleatório que torne assim improvável a repetição do ciclo. (De Giovanni, 2008) (Monticone; Amaldi, 2008)

Figura 23: Andamento da busca de um processo Tabu na região gerada por um problema VRP com 150 nodos. Pode se ver como a pesquisa continua após os mínimos locais gerando muitas oscilações.

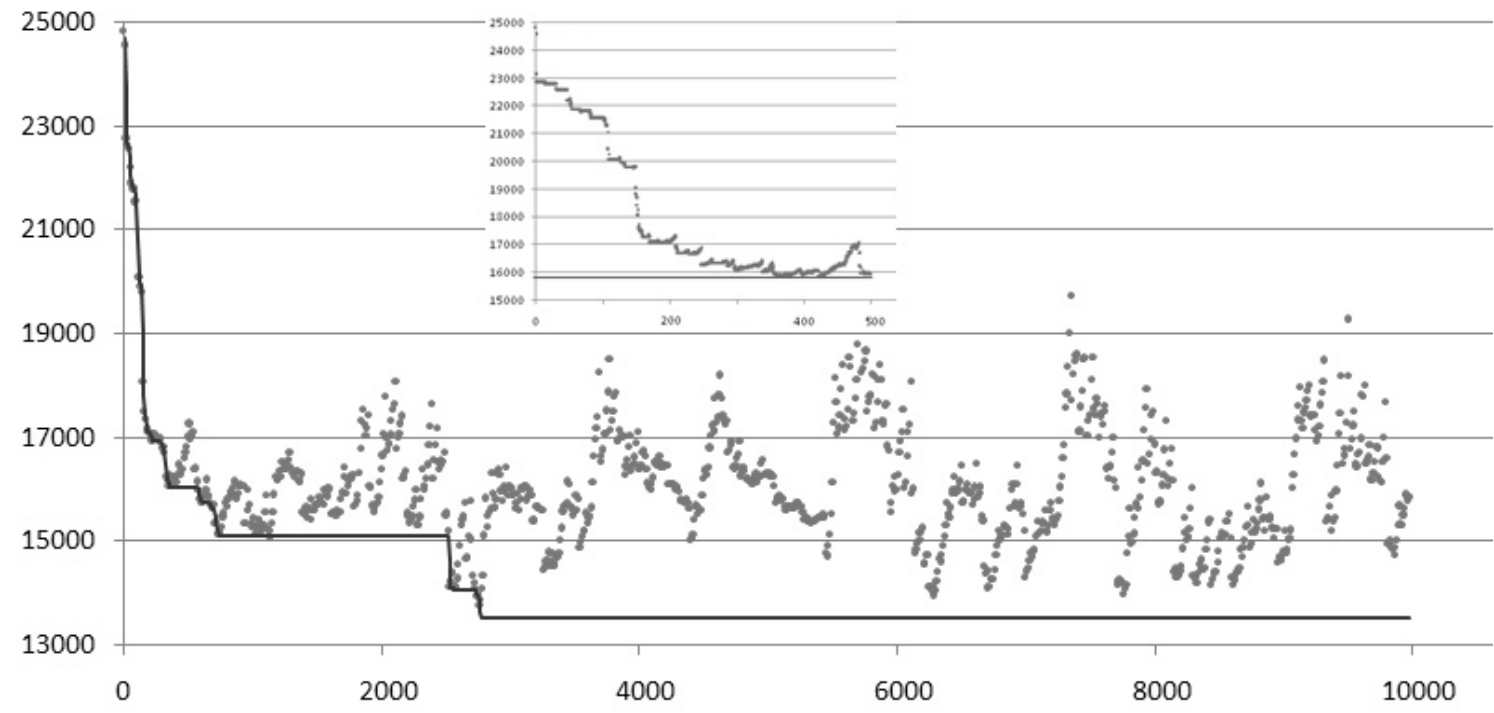

Fonte: Monticone; Amaldi (2008)

Figura 24: Andamento da busca de um processo Tabu na região gerada por um problema VRP com 50 nodos. $O$ baixo número de nós aumenta a probabilidade de ciclos que após algumas iterações são interrompidos pelo sistema randômico.

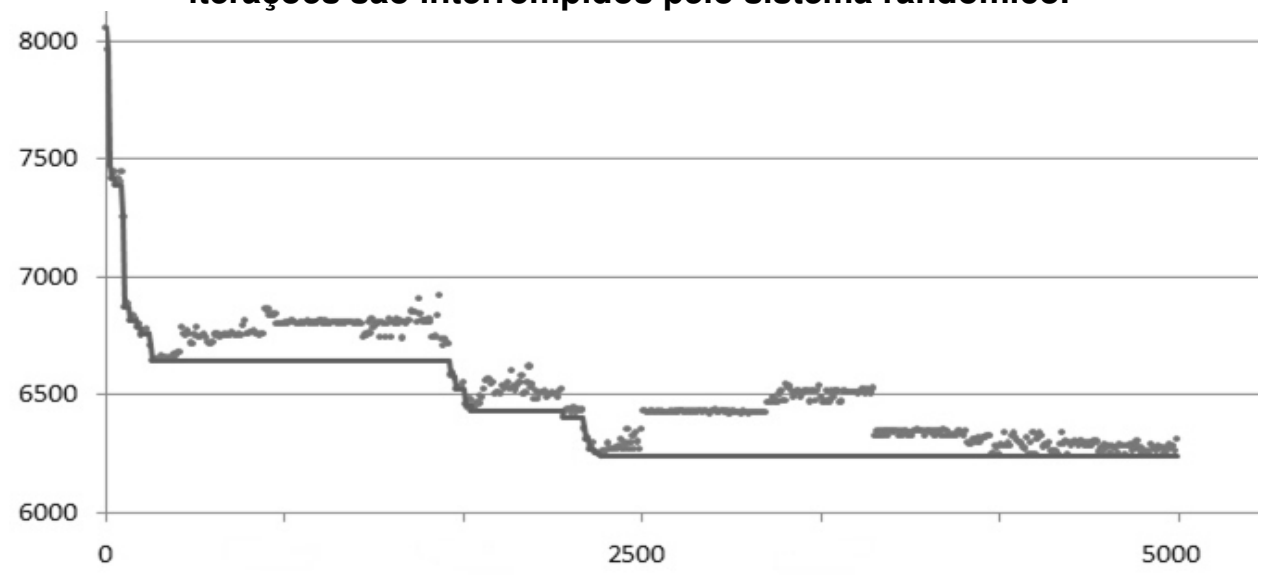

Fonte: Monticone; Amaldi (2008) 


\subsection{Algoritmos Genéticos}

Os algoritmos evolutivos são processos de cálculo que se inspiram nos princípios da evolução como heurística de pesquisa de situações ótimas. Por isso a próxima seção descreve as características da evolução natural mostrando como estas foram modeladas nos AG.

\subsubsection{Evolução de uma espécie}

A evolução é o resultado do sistema dinâmico que descreve a formação dos DNA das novas gerações a partir das antigas. Este sistema dinâmico de base é constituído por diferentes princípios que determinam o equilíbrio entre a conservação das informações genéticas adquiridas das gerações precedentes e as mutações que eventualmente levem a uma melhor adaptação ao ambiente. $O$ processo evolutivo de uma espécie pode ser interpretado como a otimização do DNA para a sobrevivência no próprio ambiente natural. (De Giovanni, 2008) (Mugnela \& Orientador: Prof. Dr. Netto, 2012)

Princípios da reprodução sexuada:

1- A reprodução faz com que o novo indivíduo tenha um DNA obtido a partir de uma composição daqueles dos dois indivíduos progenitores através de uma mistura baseada em escolhas casuais (crossing over).

2- Na geração do novo gene sempre existe uma probabilidade baixa de erro que gera pequenas mutações nas informações passadas.

3- Os seres que conseguem procurar no ambiente aquilo que for necessário, e de um jeito mais eficaz, tem uma probabilidade maior de subsistir e consequentemente de procriar. 


\subsubsection{Características dos algoritmos genéticos}

Como já foi falado:

1. Os $A G$ são algoritmos heurísticos e assim não exatos.

2. Os AG aceitam também passos de pesquisa pejorativos para fugir dos mínimos locais.

Outras características:

3. Os AG conduzem muitas pesquisas em paralelo considerando sempre um conjunto de soluções e não uma só. Em cada passo do algoritmo o conjunto de soluções considerado representa a população corrente no ambiente.

4. A população inicial é escolhida casualmente gerando uma series de soluções (indivíduos) uniformemente espalhadas no domínio de pesquisa. Se existem estudos parciais ou a suspeita de uma estratégia melhor, então uma parte dos indivíduos iniciais podem ser gerados com base nestes dados.

5. A nova população (filhos) de cada iteração do algoritmo é gerada a partir da antiga (pais) através de um modelo dos três princípios da reprodução sexuada. E possível também reintroduzir a melhor solução já encontrada a cada geração.

6. As características das soluções são codificadas em genes que formam o cromossomo (em geral binário) de modo que cada indivíduo seja univocamente reconhecido por o seu cromossomo. Na Figura 25 se pode ver alguns exemplos de cromossomos binários.

7. O individuo filho é gerado através de uma composição dos cromossomos dos dois pais, simulando o principio de cruzamento (crossing over). Existem diferentes tipos de operadores de cruzamento para os quais se recomenda a referencia do Prof. Von Zuben, Algoritmos Genéticos (AG's); na Figura 25 se pode ver a recombinação com o operador de corte duplo circular.

8. Na geração dos filhos são inseridas algumas alterações casuais que fazem o mesmo papel das mutações genéticas no mundo natural. Existem propostas 
de funções para variar a taxa de mutações ao longo das gerações para controlar o nível de pesquisa local. (Michalewicz 1996).

9. Os pais são escolhidos através de um sistema probabilístico no qual a probabilidade de se reproduzir é ligada ao melhor resultado obtido pelo individuo na avaliação através da função de otimização. É utilizada também uma taxa de casualidade na escolha dos indivíduos, sendo que esta estratégia pode ser implantada utilizando uma seleção por torneio.

Figura 25: Exemplo de recombinação dos cromossomos dos pais no filho.

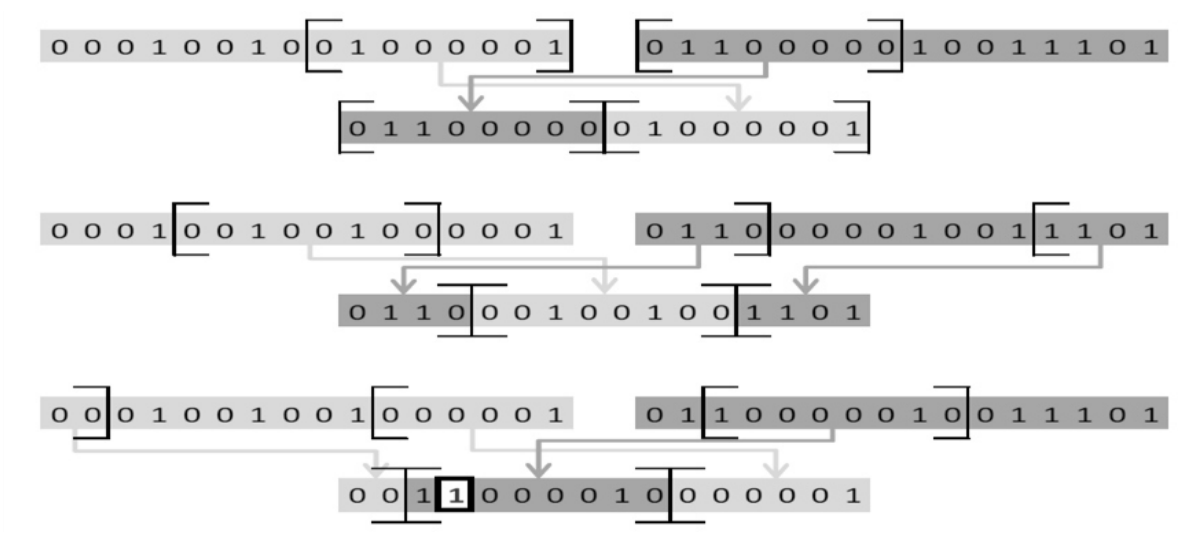

Fonte: Mugnela; Netto (2012)

\subsubsection{Pesquisa local e global}

Uma característica estrutural dos $A G$ que leva a um bom funcionamento da pesquisa é a razão que automaticamente se instaura entre pesquisa global e local. Esta razão deve ser algo dinâmico e dependente da topologia da superfície da função de fitness. A possibilidade de refinar a razão entre as duas buscas através de parâmetros faz do AG uma ótima ferramenta para a otimização de problemas em domínios enormes e com características caóticas como os de trânsito.

Pesquisa global: é a pesquisa com tendência a testar soluções uniformemente espalhadas no domínio, e assim de testar diferentes áreas para ver quais são mais interessantes.

Pesquisa local: é a pesquisa que fica em volta de um uma solução com um bom desempenho precedentemente encontrada, com a esperança que no entorno dela esteja um mínimo (máximo) local interessante. 
No caso de função de fitness muito regular, ou seja, com um número limitado de mínimos que tenham grandes bacias atrativas, muitos indivíduos iriam se agregando em grupos contidos nestas bacias. Os indivíduos gerados por pais pertencentes ao mesmo grupo ficarão limítrofes, atuando assim uma pesquisa de tipo local, enquanto filhos gerados por cruzamento de pais pertencentes a bacias diferentes continuarão fazendo pesquisa global dando a esperança de encontrar novas bacias ainda não descobertas. Na situação contrária, caso de função muito acidentada e com um número elevado de mínimos, os indivíduos pais tenderão a ficar muito espalhados no domínio inteiro gerando continuamente novos pontos bem distribuídos e favorecendo uma pesquisa mais global. Dois parâmetros ajudam o controle da pesquisa local e global. O primeiro é a taxa de mutações genéticas aplicada na geração dos filhos que pode ser aumentada para forçar uma pesquisa a um caráter mais global. O segundo é o número de indivíduos por gerações, sendo que quanto maior ele for, mais zonas serão testadas rapidamente. Como exemplo se pode escolher um número máximo de testes (ex. $10^{5}$ ) e avaliar dois jeitos de planejar a pesquisa:

1. Testar $10^{3}$ gerações de $10^{2}$ indivíduos. (tendência a pesquisa local)

2. Testar $10^{2}$ gerações de $10^{3}$ indivíduos. (tendência a pesquisa global)

A evolução natural é sujeita a outros fatores que influem nas linhas evolutivas, selecionando-as ou diferenciando-as, e que podem ser implementados constituindo mais dois recursos para o controle do balanceamento entre pesquisa global e local. Uma possibilidade seria variar o número de filhos gerados em cada iteração forçando ou limitando a competição entre os pais. A redução do número de indivíduos simula o efeito de eras rígidas (eras glaciais, cataclismos naturais) e o aumento dele as eras flóreas nas quais também os indivíduos inicialmente menos adaptados tem a possibilidade de evoluir trazendo mais diferenciação. A segunda possibilidade nasce da visão dos $A G$ como evolução em geral e não de uma única espécie e assim colocando um principio evolutivo a mais:

- Se os DNAs do pai e da mãe ultrapassam um limite de diversidade, então os dois indivíduos juntos não podem reproduzir. (diferenciação das espécies)

A proposta é a inserção de um parâmetro que impede que pais cujos cromossomos difiram demais possam reproduzir, como se fossem de duas espécies diferentes. $O$ 
principio é forçar uma série de pesquisas locais paralelas, mas isoladas, nas áreas mais interessantes do domínio sem dar a possibilidade de gerar indivíduos nas zonas intermediária das bacias dos mínimos já encontrados no domínio. O parâmetro tem que ser pensado com um caráter dinâmico, de modo a não atrapalhar a busca global no inicio do processo e ao contrario, bloquea-la na fase final, deixando só processos locais de refinamento das soluções mais promissoras. $\mathrm{Na}$ Figura 26 se pode ver como exemplo uma região com quatros mínimos locais, na primeira imagem os pontinhos representam os indivíduos no domínio e os círculos tem raio proporcional ao parâmetro que limita a diferença entre os dois cromossomos dos pais. Na segunda imagem se vê como a não utilização deste recurso conduz a geração de indivíduos intermediários entre as bacias. A utilização e o dimensionamento deste parâmetro é uma questão ainda não estudada. Foram efetuados alguns testes utilizando esta opção em ocasião de um curso do programa de mestrado da EP-USP, obtendo gráficos de diferenciação das espécies como o de Figura 27.

Figura 26: Espalhamento dos pontos em ausência do parâmetro de separação das espécies
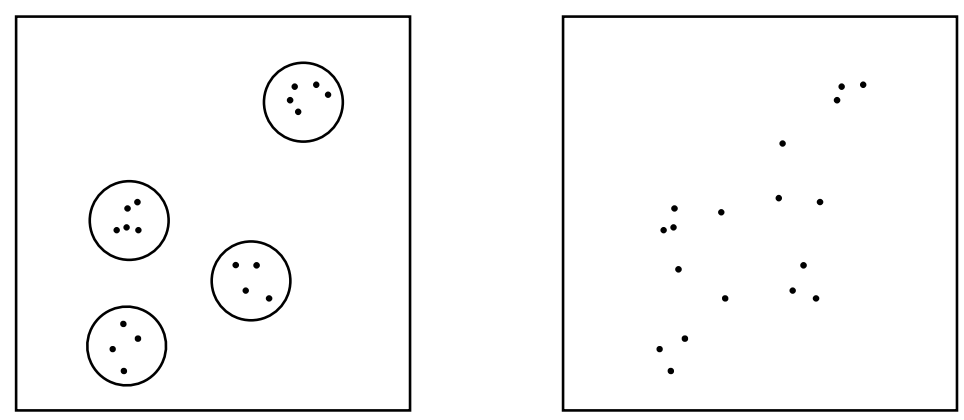

Figura 27: Espécies geradas por AG.

As gerações estão no eixo vertical e as pontas das setas indicam a extinção da espécie.

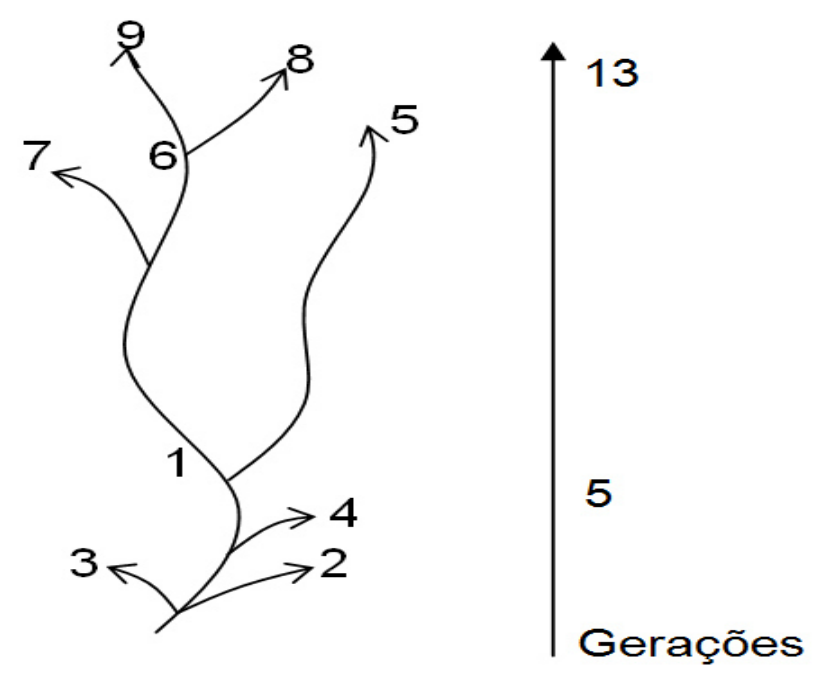




\section{Capítulo 4 - Definição do Problema}

\subsection{Introdução}

Neste capítulo é definido o problema utilizado como exemplo (bairro Itaquera, S.P.) e as técnicas escolhidas para estudá-lo. Como falado na introdução, a escolha da gestão dos fluxos direcionados ao estádio de Itaquera representa um problema modelo do uso para o qual o simulador foi pensado. As características que fazem deste problema um bom exemplo são esclarecidas na próxima seção (4.2).

Para obter os dados iniciais é preciso que já tenham sido realizadas as otimizações locais que formam o primeiro passo do processo hierárquico, no qual o simulador proposto corresponde ao segundo nível. Neste trabalho os dados iniciais para o algoritmo de simulação global proposto foram encontrados de um outro jeito que será ilustrado no próximo capítulo (5). Para conseguir o estudo hierárquico completo seria preciso realizar a integração entre o simulador proposto e os outros níveis de simulação, questão que foge dos propósitos desta dissertação. Por isso considerando os dados iniciais como já fornecidos, o texto trata somente do segundo passo hierárquico do processo inteiro, ou seja a otimização global através do simulador proposto.

O estudo global necessita de dois passos: a geração do modelo de trânsito que é utilizado como função de Fitness do algoritmo de otimização e o processo de otimização do mesmo através um algoritmo de busca heurística. (Figura 28).

O modelo de trânsito será baseado em quatro conceitos descritos a seguir:

1. Descrição da rede viária agregada em blocos.

2. Modelo de escolha das rotas especificas para os fluxos de veículos direcionados ao ponto de afluência (fluxos principais).

3. Modelo de presença do trânsito subjacente.

4. Tabelas dos tempos de transferências dos veículos através dos blocos.

O processo de otimização será baseado em dois conceitos a seguir:

1. O processo será conduzido por um algoritmo genético. 
2. Os genes são formados de dois bits representando cada bloco, significando os quatro planos operacionais pré-escolhidos dos recursos viários (resultados das simulações locais) para serem atribuídos a cada bloco.

O escopo é o planejamento dos recursos viários modificáveis (direcionamento de faixas, tempos e fases de semáforos) a fim de minimizar o transtorno do trânsito nos períodos anteriores e posteriores ao evento considerado.

Figura 28: Diagrama que representa os blocos do algoritmo. A parte verde representa o simulador utilizado como função de teste pelo algoritmo genético, repetido para cada individuo filho. A parte azul representa o interior do ciclo do algoritmo genético repetido para cada geração de indivíduos.

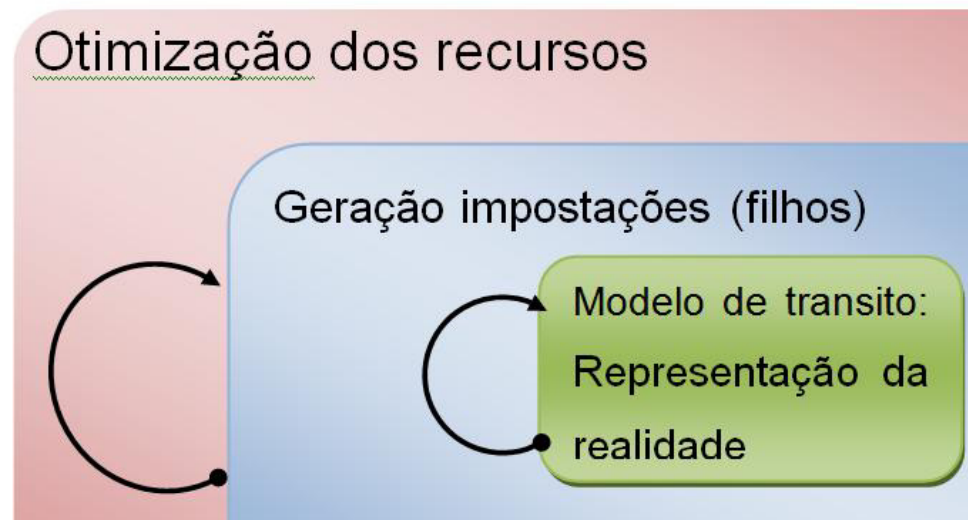

Escolha das melhores impostações

\subsection{Descrição do Problema}

O contexto do estudo é o tecido viário urbano. $O$ trânsito atrapalha a qualidade de vida de muitas pessoas e os estudos de planejamento são mais complexos devido ao alto grau de capilaridade da rede viária e ao grande número de semáforos e cruzamentos que produzem dinâmicas mais imprevisíveis e complexas que as das rodovias. As redes viárias são estudadas e planejadas para atender a padrões de trânsito específicos das regiões. Estes padrões resultam da avaliação de coletas de dados experimentais específicos de cada região, e permitem fazer cálculos e propor prognósticos sobre os tempos de deslocamento no trânsito. Os dados relevantes são: a média do número de veículos, os seus direcionamentos, as faixas horárias de ponta e os tipos de veículos presentes. (Mugnela; Netto, 2012) (Agência Mobilidade Roma) 
Figura 29: Região de São Paulo em volta do estádio de Itaquera com 6 canais de acesso.

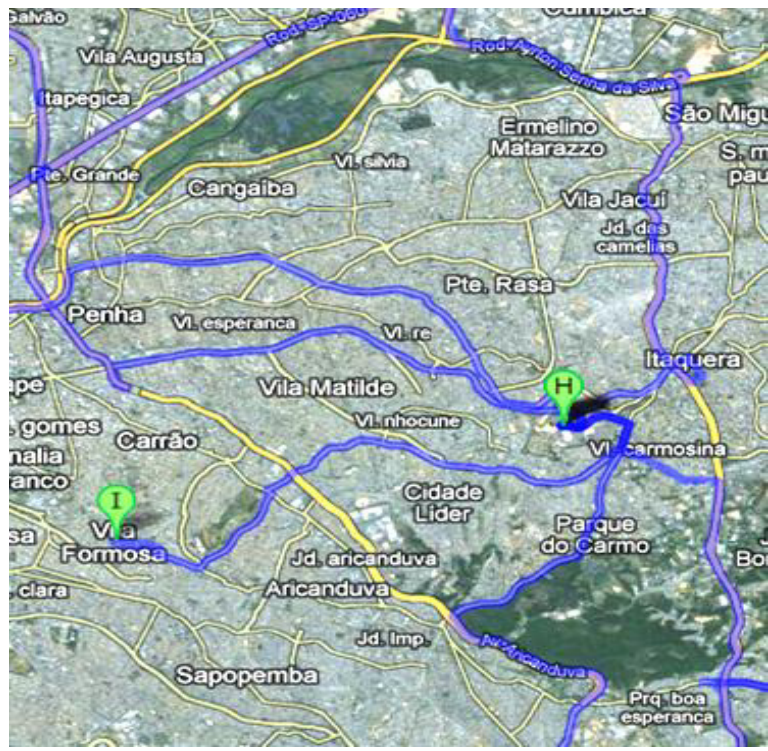

Durante eventos especiais (jogos, manifestações, espetáculos) as características do trânsito mudam muito: o direcionamento da maioria dos veículos é o mesmo, a carga de veículos é maior que o normal mesmo em faixas horárias que em geral não são de ponta. Mudando o padrão de trânsito não se tem mais nenhuma garantia de que o plano operacional em uso seja apto para minimizar o efeito de lentidão, agora para este diferente padrão de trânsito.

O estudo apresentado neste trabalho foi inspirado no trânsito antes e depois dos jogos em direção do novo estádio de Itaquera construído para a copa do mundo de 2014. A organização dos jogos referentes a copa porém é baseada em transportes coletivos especiais já que a maioria dos torcedores são turistas que dependem dos programas organizados. Portanto as situações cuja análise fazem sentido neste estudo correspondem ao uso semanal do estádio após a copa, com jogos que atraiam torcedores locais. A zona considerada ao redor se constitui dos bairros internos ao "triângulo" formado pelas rodovias em cor de laranja (Figura 29). O triângulo é fechado por baixo pelo parque do Carmo e se pode pensar que em todas as outras direções o trânsito vai se aproximando através das rodovias. Estas barreiras naturais e arquitetônicas permitem ignorar os bairros fora da zona fechada porque não influenciam o trânsito direcionado para o estádio. Também permitem selecionar um número limitado de pontos de aceso para as ondas de carga de veículos, as quais corresponderão às saídas das rodovias. Na Figura 29 se pode ver o território e os principais canais de acesso ao estádio, que serão também as rotas consideradas para os fluxos principais. 
As técnicas escolhidas para solução do problema precisam assim ser funcionais para as seguintes três características:
1. Ambiente urbano
2. Território grande
3. Fluxos intensos

Além do problema especifico considerado, muitas outras situações urbanas são caracterizadas por fluxos direcionados que envolvem territórios grandes e fogem assim da otimização conduzida através dos estudos locais. Nestas situações as zonas envolvidas não foram planejadas considerando o contexto global com o risco de sobrecarregar pontos nevrálgicos da rede, e talvez não equilibrar o trânsito nos percursos alternativos. A utilidade da otimização global é assim ligada à quantidade e ao volume de fluxos que cruzam zonas maiores, as quais são estudadas por meio de uma simulação tradicional não agregada. Também o trânsito diário das horas de ponta geram fluxos principais através da cidade. Na figura 30 se pode ver o digrama dos fluxos diários da manha na cidade de Roma. O problema dos fluxos principais gerados nas horas de pico se apresenta como uma versão múltipla do problema considerado neste trabalho, tendo uma pluralidade de pontos de atrações.

Figura 30: Fluxos diários da manha na cidade de Roma. A largura da seta è proporcional à intensidade.

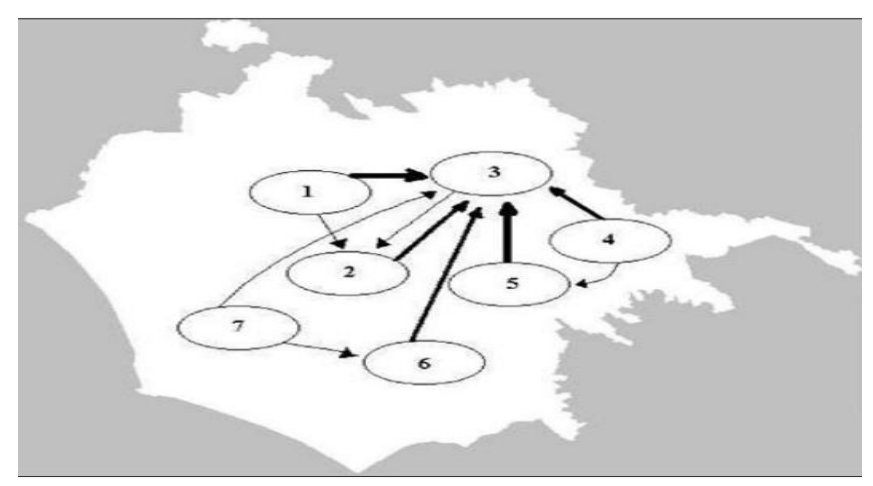

Fonte: Crisci (2002)

\subsection{Modelagem}

Ao enfrentar o problema de descrição matemática de um ambiente viário é necessário considerar três fatores que juntos geram o modelo completo. O primeiro é a descrição do tecido viário mesmo, com suas diferentes pistas e características próprias. Em seguida é preciso fornecer uma representação dos veículos incluindo as próprias rotas. A terceira parte, o coração do modelo, consiste na descrição do 
comportamento do trânsito, ou seja, a descrição da dinâmica que permite calcular a partir de uma determinada situação inicial as situações futuras da rede.

O simulador gerado neste trabalho abstrai, simplificando, os conceitos de rede viária e de comportamento do trânsito, afim de tornar possível a descrição de regiões muito grandes com uma enorme carga de veículos, limitando o tempo computacional. Para conduzir o estudo de otimização será necessário repetir a simulação milhares de vezes e o tempo exigido por cada uma será um fator importante para uma boa exploração do domínio de busca. Consultando os sites a seguir pode-se ter ideia da extensão da rede viária de São Paulo, o número de cruzamentos e semáforos e veículos circulantes. (visitesaopaulo.com)(Giovanelli, 2011)

A título de exemplo, a ferramenta de simulação micro Paramics pode gerenciar até um milhões de nós e quatro milhão de arcos, movimentando em tempo real trezentos mil veículos. Estes números parecem grandes, mas no âmbito da otimização a simulação não pode ocorrer em tempo real, mas sim milhares de vezes mais rápida. Nos anexos pode-se encontrar uma lista de softwares oferecidos pelo mercado da simulação. (http://www.paramics.it/micro.htm) (http://www.aimsun.com/wp/)

Ao apresentar este trabalho tem-se a consciência que a quantidade de dados iniciais pode comportar um trabalho muito difícil e oneroso, porém coloca-se como fundamento da realização deste estudo duas considerações:

1. A simulação de um território grande exige dados que descrevam toda a rede e todas as variabilidades entre as infraestruturas e usuários. Efetivamente o problema dos dados iniciais é típico do âmbito da simulação de trânsito e consiste essencialmente na criação de bancos de dados abertos, que possam armazenar as informações coletadas dos sistemas de controle de trânsito da cidade, bem como os resultados das simulações. Considerando a integração do simulador como quarto nível de um sistema híbrido, os dados iniciais podem ser transferidos automaticamente dos resultados das otimizações locais. Para obter o maior desempenho no estudo global o número de dados é mesmo muito grande, de modo que seria útil gerar um sistema principal em cada metrópole que integre os dados provenientes de todas as fontes disponíveis. Através de 
um esforço das instituições poderia ser criado um centro de cálculo que integre o sistema de simulação global com os bancos de dados abertos que coletam e disponibilizam os resultados de todos os estudos locais urbanos e os dados reais gerados de várias formas. Por fim, se não há disponibilidade de dados para todos os blocos, a otimização pode ser feita excluindo algum gene relativo aos blocos para os quais não se conheçam planos operacionais alternativos.

2. O problema dos dados iniciais já pode ser resolvido tecnologicamente, mesmo que economicamente não seja aplicável globalmente. Aqui são propostas três estratégias que já são, ou se prevê que possam vir a ser, adotadas nas metrópoles mundiais.

- Fazendo referencia ao projeto Grand Paris ${ }^{8}$, através o estudo da porosidade, permeabilidade e distribuição dos canos das regiões metropolitana é possível traçar mapas com parâmetros de viabilidade muito importantes, a partir dos quais seria possível calcular vários dados iniciais usando funções especificas como apresentado na seção 5.2.3.2.

- Os movimentos dos carros poderiam ser facilmente rastreados traçando suas rotas e velocidades, seja históricas que em tempo real, gerando dados da máxima precisão. Inicialmente parece algo complexo, mas já muitos carros tem algum sistema de transmissão que poderia ser utilizado. Já acontece isso utilizando os sistemas de GPS, que porém ainda são presentes apenas em uma minoria dos veículos. Também é possível rastrear os sinais dos telefones celulares que estão presentes e ligados no bolso de qualquer motorista. A coleta de dados referente a telefone é difícil já que os dados pertencem às empresas telefônicas particulares e são cobertos por leis que garantem a privacidade do cidadão. A única saída seria que fossem as empresas de telefonia as responsáveis por processar os dados e assim fornecer, para o uso final, os dados sem nenhuma referencia aos seus clientes.

- Em ultimo, como apresentado na subseção 1.2.6, novas tecnologias estão surgindo, permitindo o acompanhamento de cada veículo. Infelizmente, aspectos financeiros não permitem ainda a integração sistemática de tais tecnologias nos veículos e nas infraestruturas.

\footnotetext{
${ }^{8}$ O projeto Grand Paris foi apresentado na subseção 2.5 .2
} 


\section{Capítulo 5 - Detalhes do Simulador}

Neste capítulo se apresentam em detalhe os processos utilizados para encontrar os dados iniciais, bem como os processos internos do simulador criado.

\subsection{Decomposição da Rede Viária em Blocos}

A rede viária a ser considerada é disposta em volta do ponto para o qual se dirige o fluxo de veículos, o ponto de atração (na Figura 29 o estádio de Itaquera). A ideia é dividir a rede viária em blocos adjacentes tendo como resultado um tabuleiro com formas poligonais, servindo os lados para a entrada e a saída de veículos. Já o tempo de travessia do bloco é calculado em situação de estrada livre, após os tempos reais dependentes das situações de trânsito terem sido calculados utilizando um modelo de atraso a partir do tempo base.

\subsubsection{Forma dos blocos}

Figura 31: Junção de tecidos quadrangulares com blocos triangulares ou pentagonais.

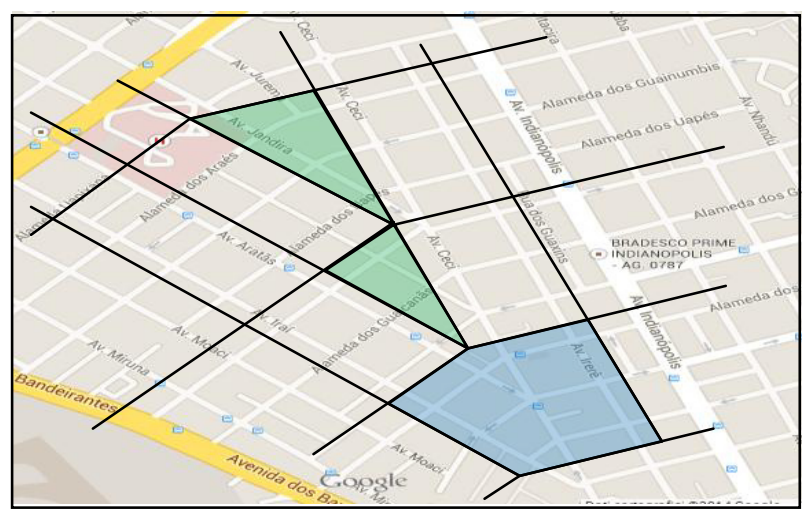

Os blocos podem ter qualquer forma poligonal a fim de identificar univocamente os lados de entrada e saída dos veículos ${ }^{9}$. O número de lados e o tamanho dos blocos pode variar de bloco para bloco. A escolha é mesmo vinculada ao tecido viário

\footnotetext{
${ }^{9}$ As questões relativas aos lados dos blocos são tratadas em detalhe na seção 5.1.3
} 
fazendo com que os lados fiquem, o mais possível, paralelos às ruas e consequentemente ao direcionamento dos veículos (Figura 31). Na inclusão do sistema em um sistema híbrido os blocos serão gerados automaticamente a partir das disposições de simulações locais. Os detalhes da integração não são tratados neste trabalho sendo que o fim é a avaliação de um domínio máximo de utilização, ou seja, testar a velocidade computacional de um modelo deste tipo.

\subsubsection{Tamanho dos blocos}

Os blocos, além de poder ter diferentes formas poligonais, também podem possuir diferentes tamanhos. Este é proporcional ao erro de aproximação de modo que os blocos precisam ficar menores em volta do ponto de atração e dos percursos onde se concentram os fluxos maiores, zonas que requerem um cálculo mais fino (Figura 32). Nas partes periféricas do mapa os blocos podem crescer em tamanho, já que os diferentes fluxos provenientes das entradas do mapa ainda não confluirão, e em média os veículos são mais espalhados.

Figura 32: Esquema de blocos de diferentes tamanho e fluxos principais da região.

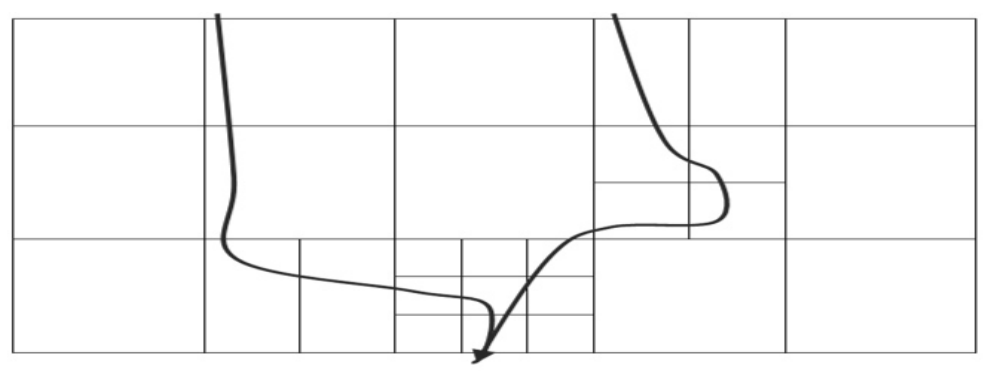

O tamanho dos blocos não só influe na precisão do modelo de trânsito, mas também modificam a função de otimização mudando o seu nível de discretização. Ao crescer o tamanho médio dos blocos o número deles diminui, considerando de tamanho fixo a zona a ser simulada. Sendo que cada bloco tem um gene, o tamanho do domínio de otimização depende do número de blocos. Se deduz que ao mudar os blocos, as diferentes funções de otimizações encontradas são discretizações com diferentes granularidades de uma única função. Esta seria uma função com um domínio enorme na comparação com as outras enquanto teria como entradas cada recurso do plano operacional de uma metrópole. A escolha de quatro planos locais para 
cada bloco corresponde a gerar uma parametrização teórica que liga as variáveis de todo um plano operacional local a uma única variável que pode assumir um entre quatro valores. A função pode ser descrita utilizando como base as novas variáveis, resultado em um domínio muito inferior ao original (a função perde parte própria da informação). A função obtida considerando as novas variáveis é a discretização da função mais geral no qual os pontos de amostram seguem estas linhas paramétricas.

\subsubsection{Borda dos blocos}

Para os veículos passarem de um bloco para outro, é necessário garantir que a saída de um lado do bloco (anterior) seja ligada a uma única entrada do novo bloco, ou seja, cada lado de um bloco deve ter contato com apenas um lado de outro bloco. Isso não limita de jeito algum a generalidade da forma dos blocos, mas é preciso garantir a integridade topológica. No exemplo de Figura 33 os blocos B1 e B2 tem quatro lados de entrada/saída, mas o bloco B3, mesmo sendo retangular, deve ter cinco lados, afim de diferenciar a saída de B3 em direção a B1 e aquela em direção a B2.

Figura 33: Exemplo de subdivisão da borda dos blocos em lados de entrada/saída dos fluxos.

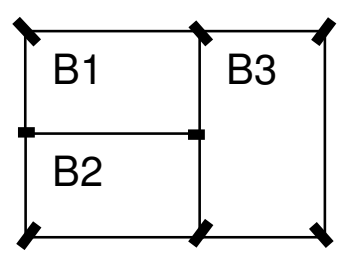

\subsection{Transferência através do Bloco}

Quando um veículo entra em um bloco escolhe o lado de saída e recebe uma carga de tempo para nele permanecer antes de poder trocar de bloco. Sendo o bloco a unidade básica, assim algo pequeno relativamente aos comprimentos das rotas, se considera um erro aceitável calcular o tempo de transferência só com base do valor do trânsito no momento da entrada, sem que este possa ser reajustado 
sucessivamente. Como se vê em Figura 34 o tempo de transferência depende do percurso que o veículo faz através do bloco, entre as combinações de entrada/saída. Nota-se também que nem todos os caminhos serão permitidos, dependendo das conexões da rede viária. O bloco representado é cruzado por um rio e uma pista suspensa, sem saídas que gerem barreiras para o trânsito.

\subsubsection{Matriz de transferência}

Figura 34: Exemplo de matriz de tempos de transferência, com média e variância e esquema de entrada/sida do bloco.

\begin{tabular}{|c|c|c|c|c|c|c|c|c|}
\hline 0.1 & 1 & & 2 & & 3 & & 4 & \\
\hline & & & 1 & 1 & 6 & 0,5 & 8,1 & 1,2 \\
\hline & $\overline{1}$ & $\overline{l 1}$ & & & 7,4 & 0,2 & 1 & 1 \\
\hline & 6,3 & 0,1 & 7,1 & 0,5 & & & 1 & 1 \\
\hline & 8,3 & 0,3 & & 1 & & 1 & & \\
\hline
\end{tabular}

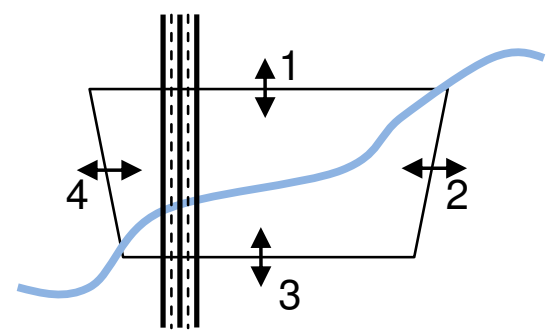

A matriz contem as informações necessárias para calcular os tempos de transferência através do bloco. Com o intuito de tornar a dinâmica mais realista são representadas também as variâncias dos tempos de travessia, de modo que na simulação tais tempos sigam uma distribuição normal com média (azul) e variância (cor de rosa) fundamentadas em dados reais.

Com o objetivo de aumentar a velocidade de computação e reduzir o gasto de memória, na implementação do modelo foi introduzido o conceito de arco, que serve para agregar o conjunto de caminhos que ligam quaisquer dois lados do polígono. A aplicação armazena os dados em um vetor geral de todos os arcos do mapa, incluindo os valores de transferência como atributos a cada objeto arco. A visualização dos tempos através uma matriz por cada bloco é útil para um fácil entendimento do processo, mas sendo estas matrizes esparsas foi conveniente optar pelo registro dos tempos de travessia no formato de $\operatorname{arcos}^{10}$. Considerando como exemplo o bloco da Figura 34 na memória do processador seriam gerados seis arcos com os valores de custo e outras propriedades.

\footnotetext{
${ }^{10}$ Para a definição da estrutura dos arcos se consulte a seção 7.1 e A2.3.
} 
É preciso sempre ter presente que o modelo será utilizado internamente ao algoritmo genético que otimiza o trânsito ajustando vários recursos viários. Os diferentes planos viários que podem ser escolhidos por cada bloco geram variabilidade nos dados, de modo que cada arco (ou matriz) precisa ter quatro valores de travessia dependendo do plano operacional escolhido para aquele bloco. O índice 0.1 na matriz de Figura 34 é o gene referente ao bloco, entendendo que para ter todos os dados são necessárias quatro matrizes com os índices $(0.0)(0.1)$ (1.0) (1.1).

\subsubsection{Coleta e geração dos dados de tempo}

A coleta de dados pode ser considerada um trabalho paralelo ao projeto do simulador, sendo que a ideia prevê a integração final com um sistema híbrido e assim a geração automática dos dados. Nesta seção é apresentado o método utilizado para a simulação apresentada no capítulo dos testes. Em outros estudos os dados podem ser calculados a partir de estudos precedentes, através de simulações ou outros métodos dependendo da disponibilidade de dados de trânsito ligados à área metropolitana considerada.

Inicialmente foram identificadas cinco categorias de infraestruturas a partir da menor, as ruas residenciais, até a maior, as pistas expressas com um número elevado de faixas. Cada categoria precisa considerar um diferente diagrama fundamental que liga a velocidade dos veículos a sua concentração.

Como antecipado na introdução da seção 5.1 os dados de tempo inicialmente considerados correspondem à uma condição de estrada livre. O processo envolve vários passos elencados e descritos abaixo.

1- Por cada dupla entrada/saída dos blocos, ou seja, para cada arco do mapa, é preciso identificar um corte através do qual o fluxo seja o menor possível. $\mathrm{Na}$ Figura 35 se encontram um bloco com a própria rede viária em preto. O corte é indicado pela linha vermelha individualizando três ruas e uma avenida. 
Figura 35: Exemplo de corte mínimo de um bloco e relativos caminhos.
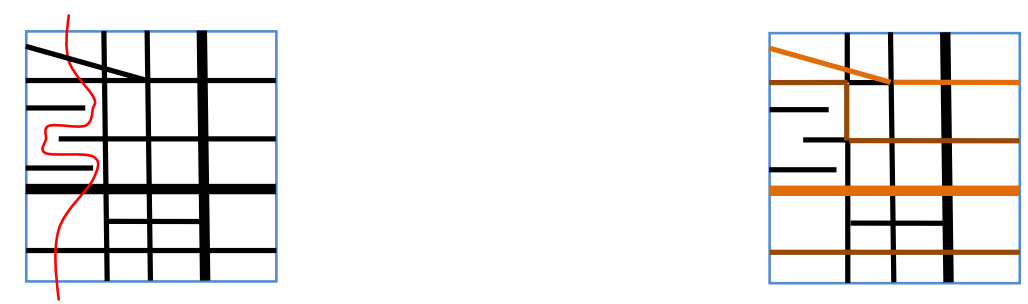

2- O tempo de transferência através cada caminho pode ser calculado a partir do comprimento do caminho e do limite de velocidade daquela categoria da infraestrutura. O tempo final será calculado como a média dos tempos de cada caminho, ponderando cada peso na capacidade de cada infraestrutura. $\mathrm{Na}$ Tabela 2 se pode ver um exemplo de cálculo referente a um bloco cruzado por três caminhos, uma avenida principal e duas ruas de bairro.

Tabela 2 : Exemplo de cálculo da média do tempo de travessia de um bloco.

\begin{tabular}{|l|l|l|l|l|l|}
\hline 1 & Rua & $30 \mathrm{~km} / \mathrm{h}$ & $2 \mathrm{~km}$ & 4 min. & 0,15 carros $/ \mathrm{m}$ \\
\hline 2 & Avenida & $50 \mathrm{~km} / \mathrm{h}$ & $2 \mathrm{~km}$ & $2,4 \mathrm{~min}$. & 0,75 carros $/ \mathrm{m}$ \\
\hline 3 & Rua & $30 \mathrm{~km} / \mathrm{h}$ & $2 \mathrm{~km}$ & $4 \mathrm{~min}$. & 0,15 carros $/ \mathrm{m}$ \\
\hline Tempo final & \multicolumn{4}{|l|}{$\left(15^{\star} 4+75^{\star} 2,4+15^{\star} 4\right) /(15+75+15)=2,9 \mathrm{~min}}$. \\
\hline
\end{tabular}

\subsubsection{Variabilidade dos tempos em função do índice de trânsito}

Através de um cálculo parecido ao apresentado na tabela 2 é possível combinar diferentes diagramas fundamentais para obter um que é modelo do conjunto dos caminhos possíveis, ou seja, o diagrama do arco. Como exemplo consideramos mesmo o segundo bloco da Figura 35 e dois diagramas para a categoria de rua e de avenida: $V_{r}(\rho)$ e $V_{a}(\rho)$ aonde $\rho$ mede a densidade especial dos veículos (carros/metro). A função da velocidade no arco pega a forma eq.7 onde $\rho$ instantâneo será calculado dividindo o número de veículos que estão transitando no arco pelo seu comprimento.

$V_{\operatorname{arco}}(\rho)=\frac{(15+75+15)}{\left(2 * \frac{15}{V_{r}(\rho)}+\frac{75}{V_{a}(\rho)}\right)}$ 
O tempo de transferência real será assim calculado dividindo o comprimento do arco pelo valor de velocidade instantânea encontrado.

\subsubsection{Uma alternativa interessante}

Uma técnica que foi avaliada e descartada, por causa da sua complexidade e da quantidade de trabalho envolvida, mas que poderia fornecer dados detalhados, utiliza o modelo "cano esponja" como resposta ao problema de caracterização dos blocos. Este modelo sugere algumas quantidades importantes que são suficientes para o cálculo aproximado dos tempos. A ideia é considerar cada bloco como uma "esponja" com, se presentes, alguns canos. Cada bloco iria ter assim as medidas de porosidade, permeabilidade direcionada, número de canos que conectem cada par de lados, e comprimento médio das travessias.

Consideremos um bloco para o cálculo do tempo de transferência entrando pelo lado $a$ e saindo pelo lado $b$. Consideremos também a presença de canos que cruzam o bloco. O tempo de transferência pode ser escrito como uma função destas quantidades como na eq. 8.

$\mathrm{pr}=$ Porosidade do tecido viário.

pe $=$ Permeabilidade, definida na direção percorrida .

$\mathrm{nc}=$ Número de canos que conectem o lado $a$ com o $b$.

$\mathrm{cm}=$ Distancia média entre os lados $a$ e $b$.

$$
T_{a-b}=f(p r, p e, n c, c m)
$$

O modelo cano esponja já foi utilizado para regiões muito amplas, usando técnicas automáticas de cálculo de porosidade e permeabilidade, mostrando assim um possível caminho para o cálculo dos dados iniciais.

Estes mesmos dados que caracterizam o bloco podem ser utilizados para descrever a curva de crescimento proporcional dos tempos em função do índice de trânsito $\rho$ como na (eq. 9). Deste modo, o cálculo do tempo real assume a forma da eq. 10. 
aumento percentual $=g(\rho, p r, p e, n c, c m)$

$T_{a-b}(\rho)=f(p r, p e, n c, c m)(1+g(\rho, p r, p e, n c, c m))$

\subsection{Designação de Rota}

Uma parte importante da constituição de um modelo de trânsito é o algoritmo de escolha das rotas dos veículos. As metodologias adotadas são duas somente, mesmo que em muitos casos seja preferível uma metodologia híbrida, combinando ambas.

\subsubsection{Designação probabilística}

Figura 36: Dados necessário para cada cruzamento da rede.
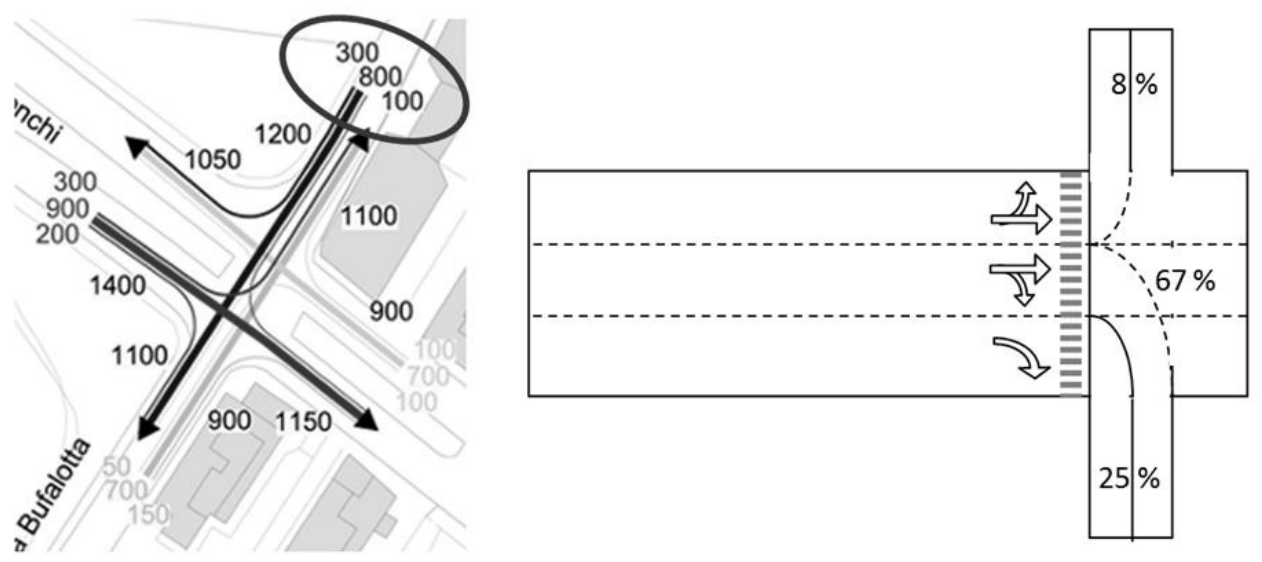

Fonte: Agência Mobilidade Roma

O primeiro jeito de conduzir os veículos na rede do simulador não requer a declaração da rota de cada veículo. Neste caso a informação, que faz os veículos escolherem a direção nas interseções, está incorporada ao próprio cruzamento. Isso significa que não cabe ao veículo escolher se continua reto ou vira à esquerda ou à direita, de modo que não é possível conhecer a priori o percurso a ser feito. A escolha é baseada em uma distribuição probabilística que distribui os veículos nas várias direções com uma distribuição casual que em média mantém os fluxos proporcionais entre eles de acordo com os dados obtidos do mundo real. Na Figura 
36 pode-se ver os dados relativos ao mesmo cruzamento mostrado na Figura 5 na subseção 1.2.1. Considerando os dados azuis, os veículos que se aproximam do cruzamento têm $67 \%$ de probabilidade de continuar reto, $25 \%$ e $8 \%$ de virar a esquerda ou direita respectivamente.

As direções, tendo uma semente casual, geram rotas imprevisíveis que não seguem uma direção específica como mostrado em Figura 37. Esta situação que parece totalmente diferente daquela real não prejudica a generalidade da simulação porque os carros são considerados todos idênticos e assim intercambiáveis. Na Figura 37 os veículos que seguem as setas vermelha e azul podem trocar de papel no cruzamento marcado pelo circulo azul, sendo que resulta indiferente qual das setas cor de laranja seguirão. Os dados iniciais para esta opção são os fluxos médios reais em cada direção de cada cruzamento como a amostra de Figura 37.

Figura 37: Exemplo de intercambo dos veículos no modelo de assinação probabilística de rota.

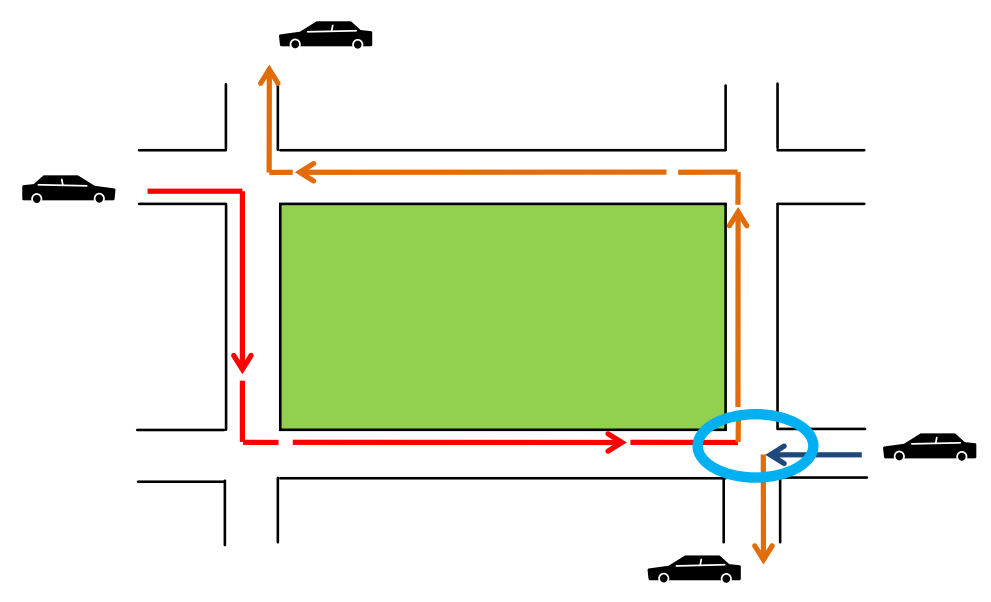

\subsubsection{Designação previa}

A segunda opção é a designação das rotas inteiras no momento de entrada dos veículos na simulação. Neste caso, os dados iniciais são mais complexos porque é preciso conhecer as rotas típicas dos usuários reais e a afluência média em cada rota. Este método é mais utilizado nos casos de estudos de rodovias ou tecidos amplos com um número reduzido de interseções.

No simulador apresentado neste trabalho será utilizado um processo de designação previa das rotas, mas deixando a possibilidade de desviar, tentando refletir a atitude 
dos motoristas ao evitar o congestionamento do trânsito. A designação previa será utilizada só para os veículos direcionados ao ponto de atração e não para o trânsito subjacente, para o qual é reservado outro tratamento ${ }^{11}$.

\subsubsection{Designação híbrida}

Os sistemas híbridos colocam diferentes pontos de designação de rota espalhados no mapa, de modo que os veículos ao ingressarem precisam só de uma parte da rota que será depois complementada nos pontos de designação mais internos da rede. A cada ponto de designação pode-se escolher entre um certo número de rotas designadas e a escolha de qual utilizar por cada veículo depende de uma distribuição probabilística, calibrada de modo análogo àquela utilizada por cada cruzamento no método probabilístico.

\subsubsection{Rotas principais}

Todas as rotas principais iniciam na periferia da rede e chegam ate o ponto de atração através do tabuleiro dos blocos. Por causa da descrição agregada da rede, as rotas acabam sendo as sequencias de blocos que os veículos cruzam até chegar ao destino. Uma vez escolhidos quais percursos utilizar como rotas principais é preciso estimar as ondas de cargas às quais cada entrada da rede será sujeita no momento do evento (jogos no estádio).

Dados iniciais:

- Rotas

- Fluxos esperados

Na Figura 38 se pode ver as seis rotas principais para o acesso ao estádio de Itaquera. O mapa foi obtido calculando com a ferramenta disponibilizada pelo Google Maps as rotas entre o estádio e diferentes pontos espalhados ao redor e

\footnotetext{
${ }^{11} \mathrm{O}$ trânsito subjacente será apresentado na seção 5.4
} 
com diferentes distancias. Como se pode ver no interior do "triângulo de rodovias" considerado, todas as rotas convergem para somente seis possibilidades. A conexão em azul mais claro indica um caminho ainda construído conjuntamente as obras do estádio.

Figura 38: Cálculo das rotas principais na região do estádio de Itaquera.

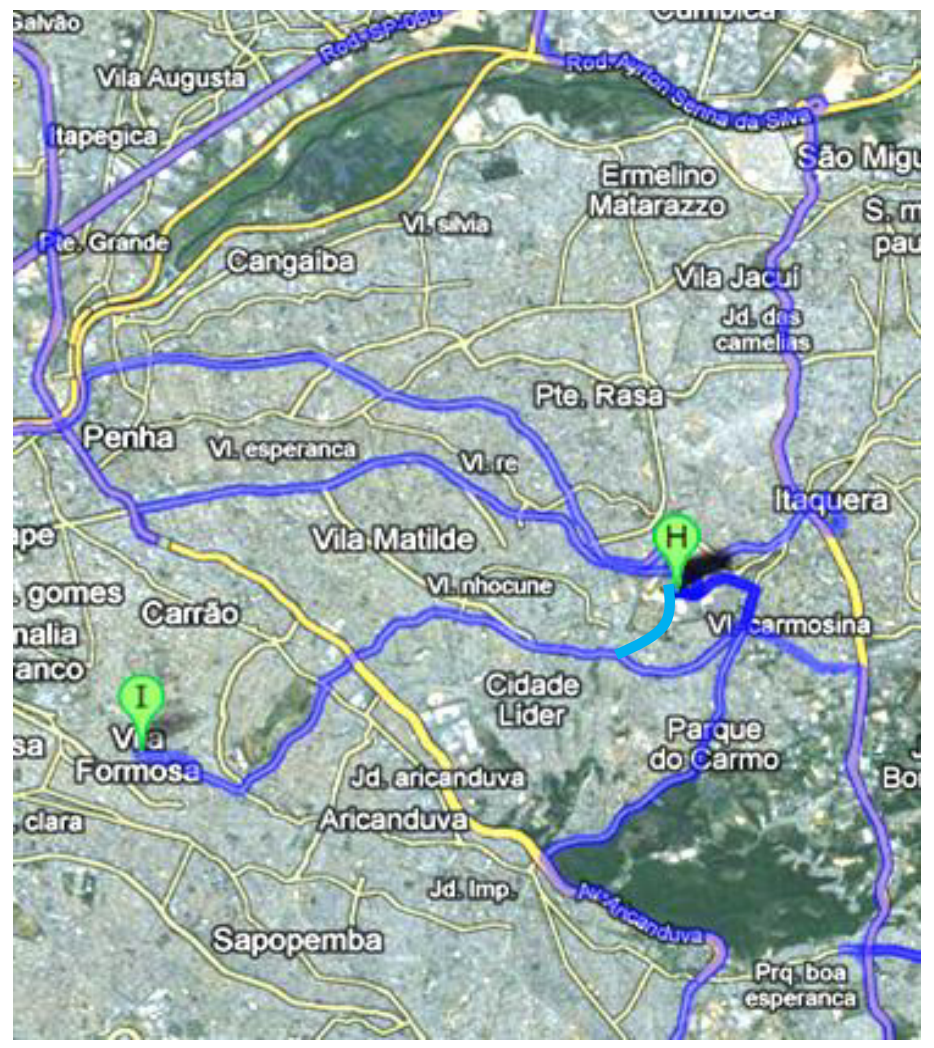

Fonte: Google Maps

\subsubsection{Encaminhamento dos fluxos principais}

Como falado no parágrafo da atribuição previa de rotas, neste modelo é necessário que quando o trânsito fica intenso o vinculo da rota seja quebrado, permitindo assim que alguns veículos possam desviar do engarrafamento. A solução de implantação escolhida é uma atribuição previa configurada como se fosse uma designação probabilística na qual as probabilidades, na condição de estrada livre, serão $100 \%$ para a direção da rota e $0 \%$ para as outras. Esta implementação torna mais fácil a gestão dos desvios e das sucessivas designações das novas rotas. Quando um veículo entra em um bloco serão propostas para ele as probabilidades de saída por cada um dos lados disponíveis, e como se fosse um cruzamento, a escolha será 
feita de acordo com o método da atribuição probabilística. Os detalhes da função que muda as probabilidades de encaminhamento são tratados nas próximas subseções.

\subsubsection{Rotas internas}

Um dos tópicos do projeto é permitir a otimização em grandes áreas, e por isso não pode ser desconsiderada a afluência ao ponto de atração por veículos provenientes dos blocos internos da área considerada. Estes fluxos precisam ser estimados do mesmo jeito que os fluxos das rotas principais, precisando designar para cada um deles uma rota que conduza até o ponto de atração ou até uma rota principal. Estes trechos compõem as rotas internas e as probabilidades de encaminhamento ao longo destas rotas também tem um valor de $100 \%$ em condição de estrada livre, igualmente às rotas principais. Cada bloco do mapa pode ser acoplado, a uma onda de carga de veículos provenientes do seu interior, e a uma rota interna. Também estes veículos podem utilizar a opção do desvio e uma vez incorporados à simulação serão totalmente indistinguíveis dos outros provenientes de áreas externas.

\subsubsection{Desvio de rotas}

Os veículos são encaminhados através dos arcos inicialmente seguindo as rotas dos fluxos principais, mas a cada saída de um arco os veículos podem escolher os desvios e não continuar no caminho principal. A gestão dos desvios é conduzida através um sistema probabilístico no qual as probabilidades ligadas a cada direção não são fixas, mas dependem da condição do trânsito. Em detalhe, considerando como exemplo a escolha entre três arcos (Figura 39): na condição de trânsito livre (P_LIV) as probabilidades serão $100 \%$ ao longo da rota principal e $0 \%$ nos desvios, mas se aproximando da saturação, as probabilidades ( $\left.P \_R E A L\right)$ mudam de modo que os três arcos saturem juntos. As probabilidades no momento da saturação (P_SAT) dependem assim da capacidade dos arcos e enfim a probabilidade real é calculada 
interpolando os casos limites como mostrado na Tabela 3 onde $N_{v}$ representa 0 número de veículos que transitam somente no arco principal. Os dados de capacidade no exemplo foram inventados para deixar o cálculo mais claro e o valor 1500 representa a soma das capacidades dos arcos. Na Figura 39 se pode ver os gráficos das probabilidades reais resultantes.

Figura 39: Exemplo de bloco e gráficos das probabilidades reais ao variar dos veículos $\mathrm{N}_{\mathrm{v}}$ no arco principal entre 0 e 1000 (dados da Tabela 3).
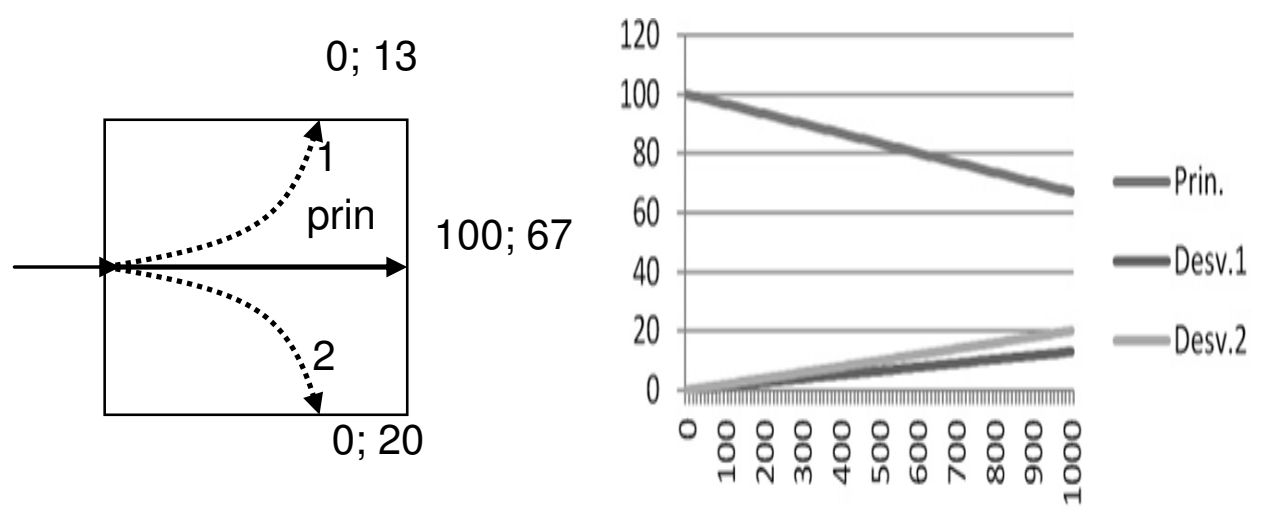

Tabela 3: Cálculo das probabilidades dos arcos.

\begin{tabular}{|l|l|l|l|l|}
\hline ARCOS & CAPACIDADE & P_LIV & P_SAT & P_REAL \\
\hline Prin. & 1000 & $100 \%$ & $1000 / 1500=67 \%$ & $100-33^{*}\left(\mathrm{~N}_{\mathrm{v}} / 1000\right)$ \\
\hline Desv.1 & 200 & $0 \%$ & $200 / 1500=13 \%$ & $13^{*}\left(\mathrm{~N}_{\mathrm{v}} / 1000\right)$ \\
\hline Desv.2 & 300 & $0 \%$ & $300 / 1500=20 \%$ & $20^{*}\left(\mathrm{~N}_{\mathrm{v}} / 1000\right)$ \\
\hline
\end{tabular}

$\mathrm{Na}$ implementação do processo o cálculo é dividido em dois passos. O primeiro é o cálculo das probabilidades na condição de saturação que pode ser executado somente uma vez, no inicio, a partir das capacidades dos arcos (eq.11). O segundo passo fornece as probabilidades reais dependentes do número de veículos no arco principal (eq.12) e precisa ser iterado a cada entrada de um veículo em um bloco.

$$
\begin{aligned}
& P_{\text {sat }}=\frac{C}{\Sigma c_{i}} \\
& P_{\text {real }}=P_{\text {liv }}-\frac{\left(P_{\text {liv }}-P_{\text {sat }}\right)}{\left(C_{p} \cdot N_{v}\right)}
\end{aligned}
$$

C é a capacidade do arco considerado.

$\sum C_{i}$ é a soma das capacidades do arco principal e dos de desvios que iniciam em um mesmo lado. 
$P_{\text {sat }}$ é a probabilidade de saturação do arco considerado.

$P_{l i v}$ é a probabilidade inicial do arco: $100 \%$ ou $0 \%$.

$C_{p}$ é a capacidade do arco principal (cada lado tem um arco principal de saída).

$N_{v}$ é o número de veículos instantâneo no arco principal.

As escolhas descritas acima comportam uma pequena aproximação enquanto que sempre há a possibilidade de algum motorista desviar, com vontade ou por erro, também quando as condições de trânsito não requeriam isso. Vale observar que o desvio neste simulador implica na passagem para blocos alternativos de modo que na realidade corresponda a uma grande mudança do caminho. Por outro lado, um veículo que saia da avenida principal para percorrer umas das vias paralelas, ficando no mesmo bloco, na visão agregada continuaria no mesmo arco sem desviar. De qualquer forma a escolha destas probabilidades necessita de um processo de calibração baseado em observações reais.

\subsection{Presença do Trânsito Subjacente}

O trânsito subjacente corresponde àquela parte de veículos presentes na rede considerada e que não estão viajando em direção ao ponto de atração. Eles participam na simulação só influenciando os índices de trânsito dos blocos, de modo que serão representados não como verdadeiros e próprios veículos rodando, mas só através de uma variável que indica a sua presença. $O$ modelo de presença consiste no fato que o parâmetro índice de trânsito de cada bloco não terá base zero, na ausência dos veículos principais, mas o valor mínimo baseado na média de afluência em cada bloco em condição de uso normal da rede.

\subsection{Discretização Temporal e Duração da Simulação}

Entre os problemas que se pretende enfrentar com este trabalho está a questão da expansão do cálculo de otimização para zonas amplas ao redor do ponto de atração. Por isso o tempo da simulação deverá ser da ordem de horas para permitir a todos 
os veículos realizar seu percurso inteiro. Aceitando uma discretização temporal numa escala de minutos, o número das iterações deve atingir alguma centenas. Também sabemos que a condição de trânsito em um trecho não pode variar muito ao longo de um minuto, de modo que este laço temporal pode ser considerado um bom compromisso entre custo e beneficio. Considerando um mínimo de uma operação por veículo para avaliar sua posição, o custo computacional da simulação será linear com o número de veículos com uma constante da ordem de centenas causada pelo número de iterações. Uma possibilidade para acelerar o processo è considerar as unidades encaminhadas não como um único veículo (micro), mas como um pacote de veículos que seguem o mesmo percurso (meso). A agregação dos veículos é feita na elaboração dos dados iniciais sendo que é tratada simplesmente como uma troca de unidade de medida. Isso corresponde a dividir os valores de carga das entradas e de capacidade dos arcos pelo valor constante $n$ de agregação desejado, trocando assim a unidade em entrada de um veículo para um pacote de $n$ veículos. As unidades encaminhadas continuam com a mesma dinâmica o que introduz uma perda de detalhe ligada ao vínculo artificial gerado entre os veículos. Por outro lado se obtém uma redução do custo computacional proporcional ao índice de agregação $n$.

\subsection{Calibração do Modelo}

Como já dito, o atual estudo não pretende concretizar um resultado e a região de Itaquera serve somente como referencia concreta a uma possível aplicação das ideias apresentadas. Por isso não houve um processo de calibração dos dados. No caso de uso futuro a simulação precisaria ter base em dados reais ou calculados através simuladores calibrados. Isso significa que não precisará de uma segunda calibração para a movimentação dos veículos através os blocos. Diferentemente o mecanismo de escolha do caminho a cada entrada em um bloco requer alguns testes para avaliar a atitude dos motoristas ao desvio. Pensando no exemplo dos jogos de futebol já se deu exemplo da diferença entre um jogo de copa e um jogo de campeonato. $\mathrm{O}$ conhecimento da cidade pelos motoristas permite buscar caminhos diferentes, enquanto dificilmente um turista desviaria de um caminho principal em uma cidade caótica como São Paulo mesmo enfrentando muita lentidão. Na Tabela 
3 foram calculadas as probabilidades finais dos arcos considerando uma situação na qual os arcos saturem juntos. Mas, considerando as atitudes dos motoristas ao desvio poderia ser necessário alterar a quota final de veículos nos desvios com uma consequente modificação das probabilidades reais.

\subsection{Resumo dos Dados Iniciais}

O problema dos dados iniciais é relevante pelo fato que uma futura integração do simulador em um sistema híbrido constaria principalmente do desenvolvimento de uma arquitetura do software fazendo a interface entre os dois níveis hierárquico do processo, assim como foi apresentado na introdução. Neste capítulo se encontra um resumo dos dados iniciais, que precisam ser fornecidos ao simulador de bloco na versão atual.

Figura 40: Região em torno do estádio de Itaquera com as 6 entradas, 25 blocos e as rotas principais e internas.

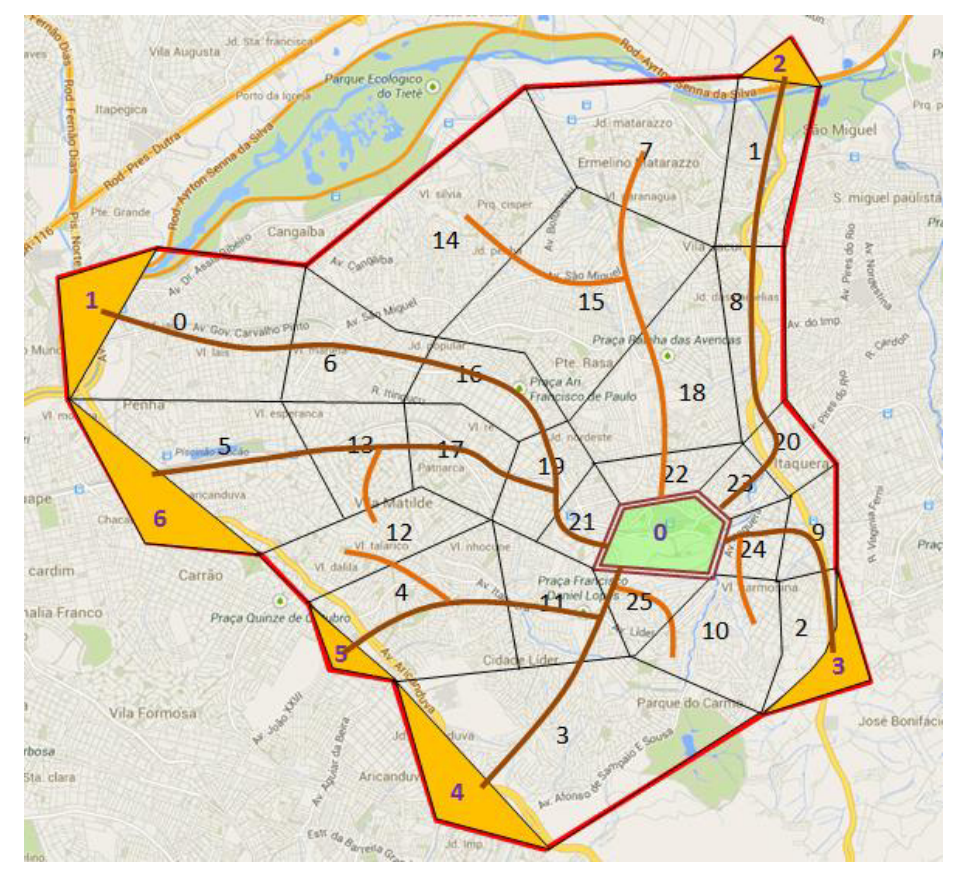

O primeiro passo é escolher o limite da simulação no mapa ${ }^{12}$ e dividir o espaço considerado em blocos tendo conta da rede viária. Em seguida é preciso escolher as entradas e identificar as rotas principais e internas. Na Figura 40 se pode ver:

\footnotetext{
${ }^{12}$ O mapa apresentado nesta seção é o utilizado nos testes do simulador. Maiores detalhes sobre os dados iniciais dos testes se encontram na seção $A 3$.
} 
- As seis entradas, marcadas por triângulos amarelos e numeradas.

- A divisão dos blocos mantendo os critérios apresentados na seção 5.1.

- As seis rotas principais marcadas em tom escuro, proveniente das seis entradas e direcionadas ao redor do estádio de Itaquera (verde).

- As rotas internas que ligam os demais blocos às rotas principais ou diretamente ao ponto de atração.

Arcos: Na Figura 41 se pode ver juntas as rotas principais e internas e os desvios permitidos, representados por setas azuis. O conjunto de todos estes caminhos, divididos em trechos internos a cada bloco, gera o conjunto dos arcos (81 no exemplo) para os quais é preciso fornecer os dados de tempo de trânsito. Considerando, que no fim do trabalho não é feito o cálculo real do plano operacional da zona mapeada, mas somente a amostra de factibilidade e utilidade, os planos operacionais opcionais e os tempos relativos não foram fornecidos. As quatro alternativas foram assim geradas aumentando e diminuindo alternativamente em 5\% os tempos das travessias nas diferentes direções. Considerando plausível a condição obtida o resultado assume um valor teórico amostrado a funcionalidade do sistema mesmo não podendo ser utilizado para a atuação no contesto real.

Figura 41: Rotas e desvios na região (arcos).

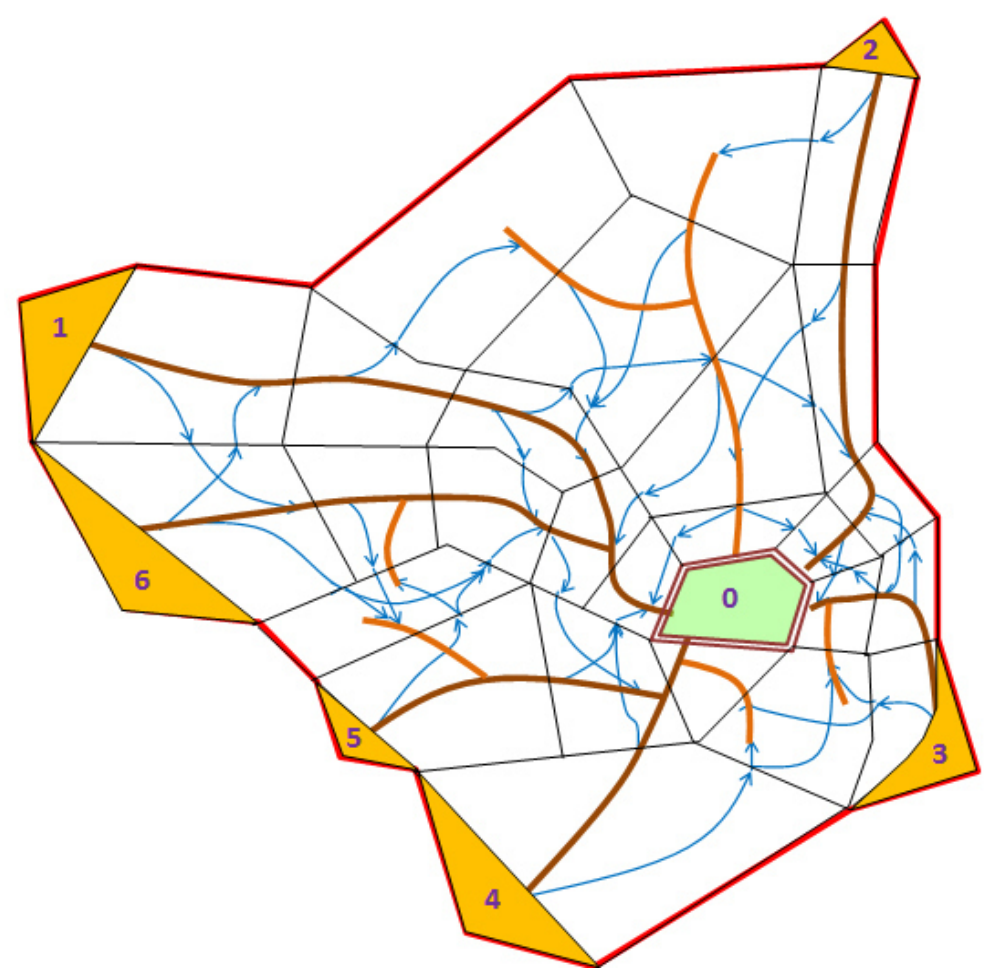


Origem dos veículos: Os veículos do trânsito principal, diferentemente do trânsito subjacente, tem um ponto de partida e um ponto de chegada determinados. A previsão dos fluxos de veículos tem que estimar o número de veículos em partida em cada lugar do mapa e ao longo de toda a simulação. Cada bloco representa um único ponto de partida e através da periferia só entram carros em um número limitado de acessos que são os inícios das rotas principais. Para cada entrada e cada bloco é preciso assim ter um vetor que descreva o acesso de veículos como mostrado na Tabela 4.

Tabela 4: Exemplo de vetor de carga para um bloco de entrada.

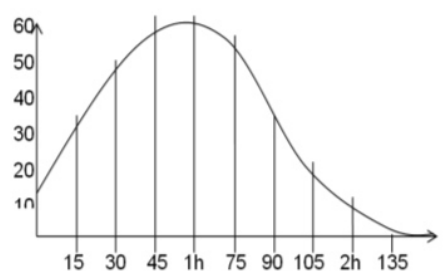

\begin{tabular}{l|lllllllllllllllllllll} 
Minuto & 1 & 2 & 3 & 4 & 5 & 6 & 7 & 8 & 9 & 10 & 11 &.. &.. &.. &.. &.. &.. &.. &.. & 150
\end{tabular} \begin{tabular}{l|llllllllllllllllllll} 
Num. veículos & 10 & 13 & 16 & 18 & 20 & 22 & 24 & 25 & 26 & 27 & 28 &.. &.. &.. &.. &.. &.. &.. &.. & 0
\end{tabular} 


\section{Capítulo 6 - Otimização}

Neste capítulo trata-se do processo de otimização, de modo que nas próximas seções são descritas as características da função de otimização e as relações com os detalhes escolhidos para o processo por A.G..

\subsection{Domínio e Teste}

O domínio de busca ou de otimização identifica aquele espaço de soluções entre os quais se pretende encontrar uma com boas características. Neste trabalho se quer otimizar os recursos, em geral, para a gestão do trânsito em uma especifica situação. A abordagem clássica seria gerar um domínio multidimensional no qual cada variável represente, em geral com valores booleanos, cada recurso de trânsito que se quer otimizar. $O$ tempo e a defasagem de cada semáforo serão representados com resolução de 5 bits e cada faixa que pode ser invertida por 1 bit apenas. Na descrição do domínio gerada da visão agregada das ruas, um grande número de semáforos e outros recursos são interligados em um número limitado de combinações dos recursos do bloco, ou seja o plano operacional da zona a que pertence o bloco. Sendo que a enorme variabilidade do conjunto de recursos viários de um bloco foi reduzida a poucos planos operacionais, o domínio diminuiu muito de tamanho tendo uma dimensão fixa de poucos bits por bloco. A contrapartida é a perda de detalhe incluída na discretização da função de otimização. Por outro lado o sistema garante a factibilidade de algo que de outro jeito resultaria complexo demais para os simuladores de trânsito tradicionais. A questão da granularidade da discretização da função de otimização depende da escolha dos blocos de modo que estas considerações já foram esclarecidas na seção 5.1.2 dedicada ao tamanho dos blocos. 


\subsubsection{Tamanho do domínio}

O gene relativo a cada bloco é representado por dois bits, assumindo assim os valores $00,01,10$ ou 11. Os cromossomos como na Figura 42 tem um comprimento de duas vezes o número dos blocos, gerando assim um domínio de ordem $10^{(3 \cdot \mathrm{Nbloc} / 5)}$, onde foi considerado $\log _{2}(10) \approx 10 / 3$.

$N_{\text {bloc }}$ : Número dos blocos

Figura 42: Exemplo de cromossomo, em cores diferentes os genes.

\begin{tabular}{|c|c|c|c|c|c|c|c|c|c|c|}
\hline Imp. Blocos & 0 & 3 & 2 & 1 & & $\ldots$ & 1 & 2 & 0 & 1 \\
\hline Cromossomo & 00 & 11 & 10 & 01 & & 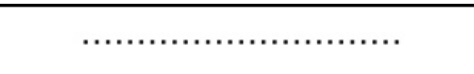 & 0 & $11 \mathrm{c}$ & 00 & 001 \\
\hline
\end{tabular}

Inicialmente foi pensada uma dupla discretização, na qual o território inteiro fosse divido em bairros como unidades de agregação para o processo de otimização, e outra mais finamente em blocos para o modelo de trânsito. A preocupação era o mal funcionamento dos métodos de otimizações quando o domínio da função tem ordem muito elevada. Como se pode ver o domínio é ligado com o número de blocos, de modo que pensando em dividir o território em 500 blocos, o domínio de otimização é de ordem $10^{300}$. Com o crescimento do domínio o A.G. perde em desempenho, mas por outro lado uma discretização grossa reduz a profundidade dos mínimos da função de otimização. A escolha foi tomada com base em simulações utilizando uma função proposta por Levy como teste e um método A.G., variando a discretização do domínio nos vários testes. Em conclusão, o número de bloco não é um problema para a otimização, e assim a discretização em bairros pode ser reduzida em sua granularidade até coincidir com a discretização necessária para o simulador (identificando cada bairro em um bloco). Nos próximos parágrafos são apresentadas a função de Levy utilizada e dois testes demonstrativos.

A função de Levy (eq.13) é considerada um teste difícil para algoritmos de otimização, pois ela tem um número variável de dimensões e um número de mínimos proporcional a quinze elevado ao número de dimensões. O mínimo global é conhecido e tem valor zero. O domínio das $y_{i}$ deveria ser estendido ate -5 , mas foi 
reduzido por um motivo técnico de implementação. Tendo o mínimo global no ponto central do domínio se consegue garantir que ele exista independentemente da discretização do domínio já que o número de intervalos em que cada dimensão foi dividida é uma potencia de dois. (Velázquez, 1999) (Adorio, 2005)

$$
\begin{aligned}
& \left\{\begin{array}{l}
f_{(\vec{x})}=\sin ^{2}\left(3 \pi \cdot y_{1}\right)+\left(y_{n}-1\right)^{2} \cdot\left[1+\sin ^{2}\left(2 \pi \cdot y_{n}\right)\right]+\sum_{i=1}^{n}\left(y_{i}-1\right)^{2} \cdot\left(1+\sin ^{2}\left(3 \pi \cdot y_{i+1}\right)\right) \\
y_{i}=\left(\left(x_{i}-0,5\right) \cdot 8\right)+1
\end{array}\right. \\
& 0<x_{i}<1 \quad \min : x_{i}=0,5 \\
& -3<y_{i}<5
\end{aligned}
$$

Na Figura 43 abaixo se pode ver como o mínimo encontrado não perde qualidade com o crescimento do domínio causado pelo detalhamento da granularidade. As funções testadas são a função de Levy em duas situações, uma com dez e outra com quatrocentas dimensões. Ao longo dos grafos, cada dimensão foi descrita com um número de bits a partir de 2 até 32 gerando domínios da ordem de 6 até 96 na primeira e de 240 até 3840 na segunda.

Figura 43: Soluções mínimas encontradas para a função de Levy de dez e quatrocentas dimensões ao crescer do número de bits utilizados para cada asse.

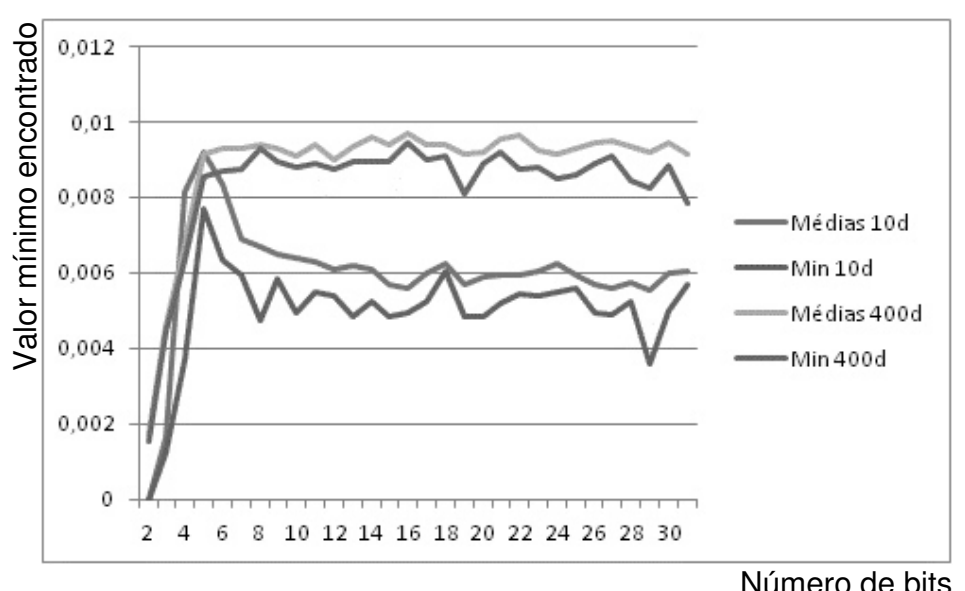

\subsubsection{Função de otimização}

O domínio é um conjunto de soluções com diferentes características. Para escolher as melhores soluções é preciso testa-las experimentando-as na situação especifica que se quer resolver. É preciso distinguir os comportamentos bons daqueles indesejados e reduzi-los a uma medida que é assim valor de fitness. A função que, a 
partir de um cromossomo (ponto do domínio), faz o cálculo do fitness ganha o nome de função de otimização (também: função de fitness, função de teste) que em geral aparece como uma média ponderada de diferentes fatores avaliados.

Exemplos de fatores avaliados no âmbito do estudo proposto neste trabalho.

$\mathrm{T}_{\text {tot }} \quad$ Tempo médio de chegada dos veículos.

$\mathrm{V}_{\text {sub }} \quad$ Velocidade média do trânsito subjacente.

$P_{\max } \quad$ Tempo da parada mais longa. Trechos totalmente parados se tornam perigosos para a irritação dos motoristas implicando problemas maiores de várias naturezas como uma condução do veículo mais prepotente ou ate brigas nas ruas.

$S_{\min } \quad$ Tempo mínimo de socorro. O tempo para a chegada de resgate ao ponto de atração. Em muitas circunstancias é preciso prever no mínimo um canal preferencial para os resgates e as autoridades. No caso deste simulador não é possível saber o que acontece no nível das ruas, de modo que este parâmetro não será considerado $\left(c_{4}=0\right)$.

Função de teste: $\quad c_{1} \cdot T_{\text {tot }}-c_{2} \cdot V_{\text {sub }}+c_{3} \cdot P_{\max }+c_{4} \cdot S_{\min }$

Os parâmetros são constantes de proporcionalidade que permitem de balancear, segundo conveniência, a preponderância entre os diferentes fatores considerados.

Neste ponto, é preciso utilizar o recurso da simulação de trânsito como único jeito de produzir as medidas que representam as entradas da função de teste. Nem todas as medidas antes consideradas são presentes na dinâmica do simulador. Por exemplo, a $V_{\text {sub }}$ não é dada por conta do modelo de presença por trânsito subjacente ${ }^{13}$. Para as medidas não disponíveis é preciso encontrar alguma outra que seja proporcional à primeira, de modo que a diferença seja absorvida pelos parâmetros de proporcionalidades $c_{\text {i }}$.

$T_{\text {tot: }}$ : Para calcular o tempo médio de chegada só é preciso memorizar ao longo da simulação o momento de chegada de todos os veículos e no final calcular a media. Este valor representa uma parte preponderante do valor de fitness já que o tempo

\footnotetext{
${ }^{13} \mathrm{O}$ trânsito subjacente foi tratado na seção 5.4
} 
médio de trânsito corresponde de fato àquilo que gera o incomodo e a insatisfação nas pessoas.

$\mathrm{V}_{\text {sub: }}$ Os veículos subjacentes também são atrasados por causa dos fluxos, gerando incomodo diretamente nas pessoas que os conduzem. Sendo os veículos dos fluxos principais a maioria, os pesos atribuídos as duas quantidades precisam estar em acordo com as proporções de veículos. O cálculo será baseado na média de presença nos blocos, ponderadas pelo número de veículos subjacentes presentes. Deste jeito para cada bloco se obtém um valor que considera quanto o trânsito foi caótico e quantos veículos subjacentes foram atrapalhados por isso.

Na versão aqui proposta são considerados somente os dois atributos acima, e que representam a solução direta do problema de trânsito (eq. 15). Em versões futuras poderão ser consideradas funções de otimização mais complexas, tendo em consideração que as aproximações dos dados e da dinâmica faz com que um excessivo detalhe na fase de avaliação possa na verdade vir a considerar dados irrelevantes ou casuais.

$F=c_{1} \cdot T_{\text {tot }}-c_{2} \cdot V_{\text {sub }} \quad$ com: $\frac{c_{1}}{c_{2}}=\frac{N_{v_{-} \text {prin }}}{N_{v_{-} \text {sub }}}$

\subsection{Algoritmo Genético}

O Algoritmo genético, como representado na Figura 44 inicia gerando uma série de indivíduos casuais, o que corresponde a gerar os seus cromossomos escolhendo casualmente cada gene. Assim, o ciclo interno avalia todos os indivíduos entre os quais só alguns serão escolhidos para serem pais da próxima geração. Entre os cromossomos escolhidos para os cruzamentos, as probabilidades de serem pais, são proporcionais aos resultados apresentados no teste, a fim de favorecer probabilisticamente as melhores características. A partir dos pais é preciso então gerar uma nova série de indivíduos filhos voltando ao ponto de partida. Este ciclo externo se repete pelo número desejado de gerações. 
Figura 44: Diagrama de fluxo do algoritmo genético.

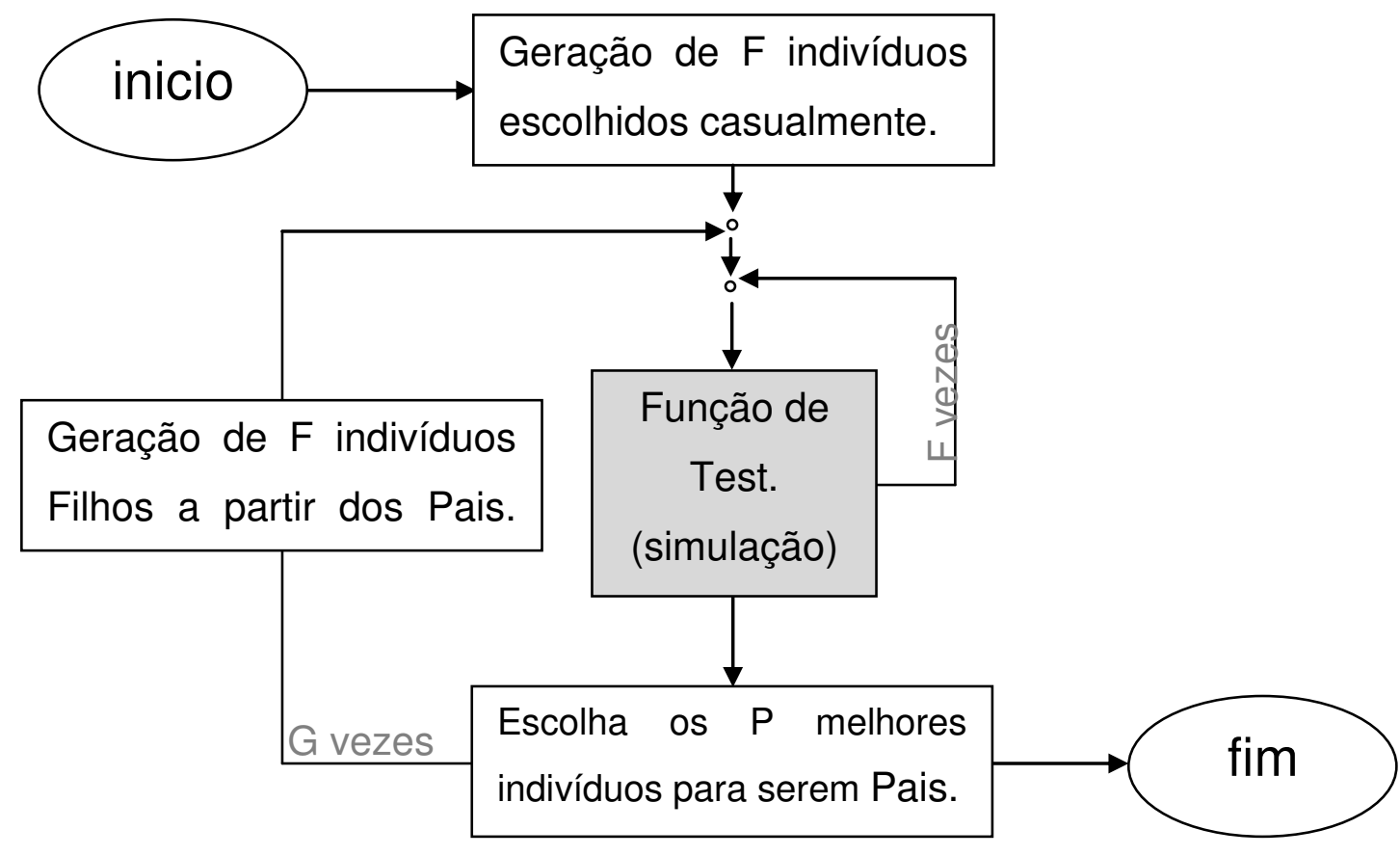

$F=$ Número dos indivíduos Filhos.

$P=$ Número dos indivíduos Pais.

$G=$ Número de Gerações.

Custo computacional: F·G·(custo da simulação)

O AG foi criado propositalmente para esta aplicação. A seguir, encontram-se as escolhas dos operadores e parâmetros do AG.

1. Crossover: O operador de crossover utilizado é o corte duplo circular, gerando dois filhos a cada vez; o primeiro com a testa do cromossomo do pai e a cauda da mãe e o segundo ao contrário (seção 6.2.1).

2. Limitação dos pais: Foi inserido um parâmetro de corte para os indivíduos que não alcançam um valor mínimo calculado neste modo: $\min +(\max -m i n) \cdot P_{\text {corte, }}$ onde $\mathrm{P}_{\text {corte }} \mathrm{e}$ uma probabilidade e pode ser fixa ou variável ao longo das gerações.

3. Cálculo das probabilidades: A probabilidade de cada individuo pai ser escolhido para uma reprodução foi calculada como uma proporção direta dos valores de fitness no interior do grupo, método conhecido como "roulette wheel" (Michalewicz, 1996) (seção 6.2.2). 
4. Mutações: O parâmetro de mutações pode ser constante ou mudar linearmente ao longo das gerações, sendo em média inferior a $1 \%$.

5. Indivíduos: O número de indivíduos pode ser constante ou decrescer linearmente ao longo das gerações. O número inicial varia de teste em teste, ficando entre 100 e 1000 indivíduos.

6. Persistência no teste: Usando o conceito de persistência, a simulação é repetida três vezes e o valor de fitness é a média dos resultados (seção 6.2.3). (Zuben, 2000)

\subsubsection{Corte duplo circular}

A reprodução é dividida em duas fases, a primeira gera a nova população de filhos cruzando os Pais com as Mães, mas sem fazer nenhuma mutação, sendo posteriormente introduzidas as mutações com uma taxa de probabilidade fixa. No corte duplo circular ${ }^{14}$ o cromossomo dos pais é considerado como circular. Assim se corta em duas partes iguais, em um ponto escolhido casualmente.

\subsubsection{Cálculo das probabilidades para os pais}

Tabela 5: Cálculo das probabilidade de ser Pai a partir do valor de fitness.

\begin{tabular}{|l|l|l|l|}
\hline Individuo & Fitness & Max-fitness & Prob. \\
\hline 1 & 102 & $112-102=10$ & $10 / 57=17,5 \%$ \\
\hline 2 & 112 & 0 & $0 \%$ \\
\hline 3 & 98 & 14 & $24,5 \%$ \\
\hline 4 & 100 & 12 & $21 \%$ \\
\hline 5 & 106 & 6 & $10,5 \%$ \\
\hline 6 & 101 & 11 & $19,5 \%$ \\
\hline 7 & 108 & 4 & $7 \%$ \\
\cline { 2 - 4 } & Max $=112$ & tot=57 & \multicolumn{1}{|l}{} \\
\cline { 2 - 3 } & \multicolumn{2}{|l}{} \\
\cline { 2 - 4 } & &
\end{tabular}

\footnotetext{
${ }^{14}$ Para exemplo do corte duplo se faz referencia à seção 3.5.2 e Figura 25.
} 
Tabela 6: Cálculo da probabilidade de ser Pai a partir do valor de fitness. $x=$ rand()\%100

\begin{tabular}{|c|c|}
\hline$x<17,5$ & 1 \\
\hline $17,5 \leq x<42$ & 3 \\
\hline $42 \leq x<63$ & 4 \\
\hline $63 \leq x<73,5$ & 5 \\
\hline $73,5 \leq x<93$ & 6 \\
\hline$x \geq 93$ & 7 \\
\hline
\end{tabular}

As Tabelas 5 e 6 reportam um simples exemplo de cálculo das probabilidades de cada individuo de se reproduzir utilizando sete indivíduos pais. O melhor indivíduo será reintroduzido a cada geração, mas o teste do seu fitness não será repetido, evitando assim um gasto computacional desnecessário.

Neste exemplo a função precisa ser minimizada, de modo que primeiro se encontra o pior valor de fitness para subtraí-lo dos outros valores. Desta forma se tem então valores maiores para os indivíduos "bons" e valor nulo para o pior individuo, sendo estes proporcionais a probabilidade de se reproduzir. Utilizando a segunda tabela se pode escolher os pais utilizando um gerador casual. (Zuben, 2000)

\subsubsection{Persistencia no teste}

A dinâmica do simulador contém sementes de casualidade de modo que o valor de fitness de cada indivíduo varia repetindo a simulação. Para se ter uma medida certa do desempenho do individuo é preciso repetir a simulação algumas vezes e avaliar a média dos resultados. O número das repetições influi diretamente no custo computacional limitando a possibilidade de aplicação do software. É preciso considerar que muitos indivíduos são excluídos da reprodução e descartados a cada geração, indivíduos para os quais não seria preciso ter um valor exato do fitness. A solução escolhida prevê que se a primeira simulação restitui um fitness perto do ótimo já encontrado o teste fica repetido para três vezes, caso contrario a persistência não é aplicada. 


\section{Capítulo 7- Implementação}

O simulador e o AG foram implementados em $\mathrm{C}++$ utilizando um compilador Microsoft Visual Studio. O custo computacional total é dado por cinco ciclos principais aninhados. No interior da simulação os ciclos dos veículos, dos instantes de tempos e da persistência do teste; no AG os ciclos dos indivíduos e das gerações. O custo total segue assim a (eq.16) aonde $C$ é uma constante que foi avaliada na seção dos testes.

$$
\text { Custo }_{\text {tot }}=C \cdot N_{\text {gen }} \cdot N_{\text {ind }} \cdot N_{\text {veic }} \cdot N_{\text {test }} \cdot \frac{T_{\text {sim }}}{\Delta T}
$$

\subsection{Estruturas de Dados}

Aqui são apresentadas as estruturas de dados utilizadas e as tipologias de dados que contenham. Para a definição completa das estruturas pode-se consultar os anexos.

1. Estrutura principal $\operatorname{prin}^{15}$ é utilizada para conter os dados do mapa, de carga, dos veículos e do resultado da simulação. Alguns dos dados elencados na Quadro 4 precisam de dados complementares que nesta seção não foram inseridos.

\section{Quadro 4 : Conteúdo da estrutura de dados principal do simulador}

\begin{tabular}{|c|c|c|}
\hline Dados da mapa & Dados de carga & Dados das simulações \\
\hline $\begin{array}{ll}\text { - } & \text { N. entradas } \\
\text { - } & \text { N. saidas } \\
\text { - } & \text { N. blocos } \\
\text { - } & \text { N. arcos } \\
\text { - } & \text { Vetor dos arcos } \\
\text { - } & \text { Vetor refarco } \\
\text { - } & \text { Genes dos blocos }\end{array}$ & $\begin{array}{l}\text { - Vetor dos veículos } \\
\text { - Vetores de carga das } \\
\text { entradas } \\
\text { - Vetores de carga dos } \\
\text { blocos }\end{array}$ & $\begin{array}{lll}\text { - Tempo minimo } & \text { de } \\
\text { chegada a longo da } & \text { otimização }\end{array}$ \\
\hline
\end{tabular}

\footnotetext{
${ }^{15}$ A declaração da estrutura prin é disponível nos anexos na seção 10.2.1.
} 
2. Estrutura do AG população é utilizada para conter os dados dos individuos ao longo da otimização.

- Vetor dos individuos

- Melhor solução da geração

3. Estrutura dos arcos (Quadro 5); arco e refarco ${ }^{16}$. Contem os dados de um único arco e compõe o vetor dos arcos e refarco da estrutura prin. A divisao dos dados entre as duas estruturas relacionadas é necessária porque muitos arcos não são reais mas servem só para a carga dos veículos. Todos estes arcos precisam só dos dados contidos na estrutura arco e não os da refarco.

\section{Quadro 5 : Conteúdo das estruturas dos arcos.}

\begin{tabular}{|c|c|c|}
\hline Dados de custo & $\begin{array}{c}\text { Dados de } \\
\text { encaminhamento }\end{array}$ & Dados de utilizo \\
\hline $\begin{array}{l}\text { - Vetor dos } \\
\text { custos }\end{array}$ & 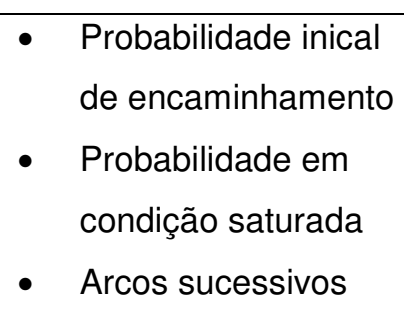 & $\begin{array}{l}\text { - } \quad \text { Bloco qual pertencia } \\
\text { - } \quad \text { Capacidade maxima de veículo } \\
\text { - } \quad \text { úmero de veículos do trânsito } \\
\text { - } \quad \text { Nubjacente } \\
\text { - Número total de veículos no arco }\end{array}$ \\
\hline
\end{tabular}

4. A estrutura dos veículos vea pode ser considerada como um único veículo (microscopico) ou um pacote minimo de veículos (mesoscopico) dependendo se os vetores de entradas foram escritos agregando os veículos. Contem os dados instantaneo de posição e dinamica do veículo e compoe o vetor dos veículos da estrutura prin.

- Arcos nos quais está transitando

- Hora de saída do bloco

5. Estruturas dos Indivíduos individuo. Contem os dados de um único individuo e compõe o vetor dos indivíduos na estrutura população.

- Vetor dos genes do individuo

- Resultado da simulação

\footnotetext{
${ }^{16}$ A decalração das estruturas arco e refarco são anexadas na seção A2.3.
} 


\subsection{Arquivos de Leituras dos Dados Iniciais}

Os dados iniciais são lidos de dois arquivos .xt $^{17}$ que neste trabalho foram gerados a partir de uma tabela de Excel. Os dados foram organizados em uma planilha de Excel reunindo os campos fórmulas para o tratamento preparatório dos dados como apresentado na seção 5.2.2 na Tabela 2. Em uma segunda planilha uma série de fórmulas com sementes casuais gera os dados relativos às ondas de carga dos veículos principais. Transcrevendo as planilhas inteiras para um dos arquivos .txt, se obtém os arquivos no formato legível por uma função especifica do simulador. O primeiro arquivo load_data_map contem todos os dados do mapa, o segundo load_onda_carga contem as ondas de carga dos veículos.

\subsection{Funções do Simulador}

Nesta e na próxima seção descreve-se a estrutura do algoritmo evidenciando as funções que foram implementadas distintamente. Os esquemas desta seção são relativos assim à organização escolhida na escrita do código. Outras organizações, constituídas por menos ou mais níveis de hierarquia das funções, podem ser utilizadas a escolha do programador sem que isso mude alguma coisa no resultado compilado do código.

O Simulador é uma função já que o main do programa está no nível do processo de otimização. O simulador contém várias subfunções que tratam parte dos processos, trabalhando alternativamente na estrutura prin. Em um ciclo, que se repete até todos os carros chegarem ao ponto de atração, se encontra o cálculo da iteração (iter) que contém todas as dinâmicas relativas à movimentação dos veículos. Entre estes processamentos foram destacadas as funções para o cálculo das probabilidades dos arcos e do tempo de transferência real, como discutidos nas seções 5.3.8 e 5.2.3.1 (funz1 e funz2). A função para imprimir (stampa) escreve os dados da estrutura principal em um arquivo e através dos parâmetros booleanos pode ser ativada

\footnotetext{
${ }^{17}$ Pode se encontrar uma das duplas de files utilizadas na seção dos anexos A3.
} 
inteiramente, só em parte ou desativada. Na Figura 45 se pode ver o esquema hierárquico das funções e os tipos de input/output.

Figura 45: Hierarquia das funções no Simulador.

int simulacao(prin);

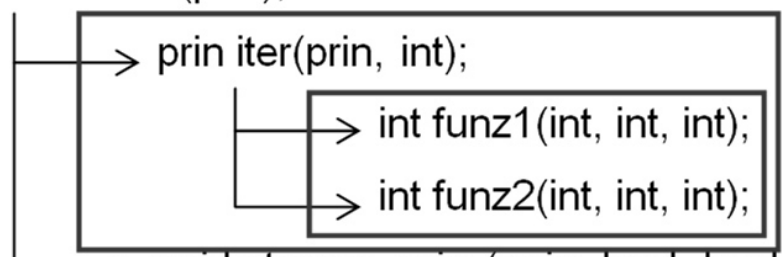

void stampa_prin ( prin, bool, bool, bool, bool, bool);

\subsection{Funções do Otimizador}

As primeiras funções que comparecem no main (Figura 46) não pertenciam ao AG, mas tratam a leitura dos arquivos de carga dos dados (load_data e load_carga). A função genvea organiza a estrutura dos veículos principais lendo os dados de carga e inicializando os veículos em uma série de arcos virtuais utilizados para a entrada dos veículos. No interior do ciclo das gerações é computada a simulação para cada individuo e preparada a nova geração de indivíduos intervindo na estrutura dados da população (riproducl). Durante a reprodução por cada dupla de indivíduos é computado o crossover dos genes como apresentado na seção 6.2.1 (euris1).

Figura 46: Hierarquia das funções no processo de otimização.

main();

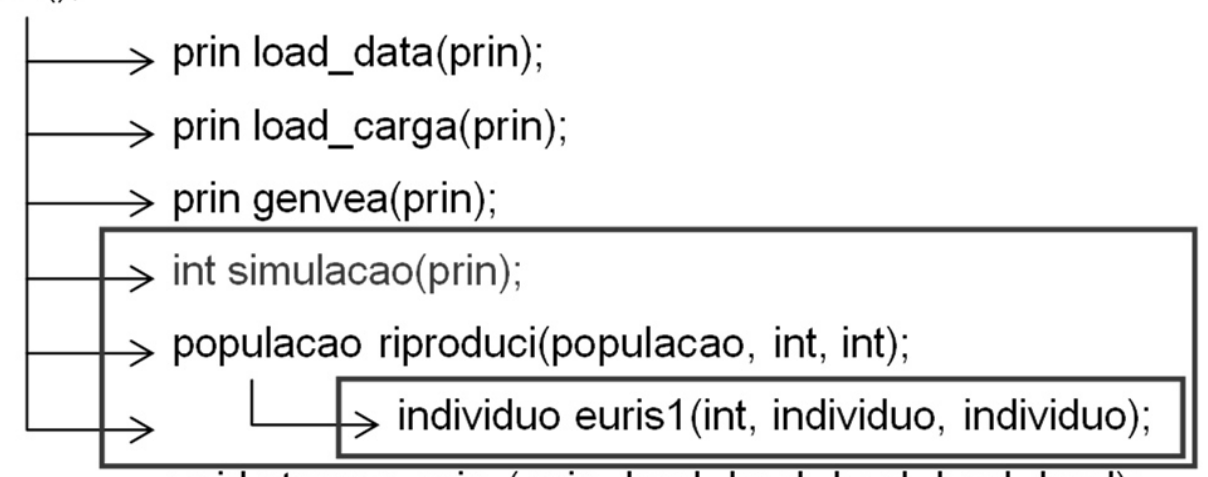

void stampa_prin ( prin, bool, bool, bool, bool, bool); 


\section{Capítulo 8 - Resultados}

\section{Teste 1: Velocidade da simulação}

Nesta seção de testes foi avaliada a velocidade do algoritmo (Tabela 7) deduzindo a constante de proporcionalidade $C$ na equação (13) apresentada na introdução do capítulo 7 e reportada em baixo. O recurso que bloqueia a persistência e a eliminação progressiva dos veículos que chegam ao ponto de atração permite um significativo incremento da velocidade cortando onde não são necessários os ciclos da repetição dos testes e dos veículos.

Custo $_{\text {tot }}=C \cdot N_{\text {gen }} \cdot N_{\text {ind }} \cdot N_{\text {veic }} \cdot N_{\text {test }} \cdot \frac{T_{\text {sim }}}{\Delta T}$

Tabela 7: Medida experimental da constante da função do custo computacional

\begin{tabular}{|l|l|l|l|l|l|l|}
\hline Custo $_{\text {tot }} / 10^{9}$ & $N_{\text {gen }}$ & $N_{\text {ind }}$ & $N_{\text {veic }}$ & $\frac{T_{\text {sim }}}{\Delta T}$ & $N_{\text {test }}$ & $C$ \\
\hline 0,8 sec. & 10 & 10 & 2670 & 82 & 3 & 11,8 \\
6 sec. & 10 & 100 & 2670 & 85 & 3 & 8,8 \\
27 sec. & 500 & 10 & 2670 & 79 & 3 & 8,6 \\
235 sec. & 500 & 100 & 2670 & 78 & 3 & 7,5 \\
\hline
\end{tabular}

O propósito do simulador proposto neste trabalho é o gerenciamento de fluxos de veículos que ocupam grandes áreas da metrópole, e que assim fogem da capacidade da otimização clássica que consideram singularmente cada recurso do plano operacional de trânsito (semáforos, faixas, placas). Os resultados obtidos mostram que este tipo de simulação pode lidar com domínios globais que alcançam as metrópoles modernas. Considerando um caso de fluxos que envolvem $10^{5}$ veículos por um período de 300 minutos, com 3 testes por cada individuo e $10^{5}$ indivíduos testados no total o custo fica de ordem 13 ainda admissível como custo total da otimização. Considerando que os veículos podem ser considerados em pacote de 10 cada e que no valor não são considerados os veículos do trânsito subjacente, o exemplo simula uma condição real na qual os veículos presentes nas ruas podem ser de alguns milhões.

Foi avaliada também a possibilidade de uma implementação alternativa que gasta mais espaço de memória reduzindo o tempo de cálculo. Na implementação 
escolhida por cada instante de tempo e por cada veículo é necessário verificar se ele precisa mudar de bloco ou não. Na implementação alternativa se considera um vetor que mantém estas informações, de modo que o custo deixa de ser proporcional a $N_{\text {veic }} \cdot N_{\text {test }} \cdot \frac{T_{\text {sim }}}{\Delta T}$ passando a ser proporcional a $N_{\text {veic }} \cdot N_{\text {test }} \cdot \sqrt[2]{N_{\text {bloc }}}$ onde a raiz do número de bloco é proporcional ao comprimento médio das rotas. Neste segundo caso é necessária uma estrutura de dados de ordem $N_{\text {veic }} \cdot \frac{T_{\text {sim }}}{\Delta T}$ para manter a ordem de movimento dos veículos. No mais, a implementação utilizada apresenta uma constante de proporcionalidade muito pequena (ordem 1), diferentemente a implementação alternativa teria uma constante de ordem maior limitando a velocidade real a um valor parecido daquela escolhida.

\section{Teste 2: Grau de eficiência teórica}

A utilidade do sistema proposto é ligada à capacidade efetiva de melhorar uma situação de trânsito. Este melhoramento depende primariamente da distribuição dos valores de fitness dos pontos da função de otimização. Para motivar este tipo de abordagem o co-domínio da função de otimização precisa ser suficientemente amplo pra ter um margem efetivo de ganho. Um co-domínio muito amplo em proporção da média comporta que as melhores soluções sejam bem mais favoráveis das outras. No contrario se a variância dos valores do co-domínio (fitness dos pontos) é muito pequena relativamente a media, o valor ótimo será pouco vantajoso quando confrontado com a media. Neste segundo caso é claro que não vale a pena atuar o estudo de otimização. Este teste mostra que o problema tratado pertencia a primeira categoria, motivando assim a fase de busca heurística.

Tabela 8: Margem teórico de melhoramento

\begin{tabular}{l|r|r|r|r|r|r|r|r|r}
\hline Veículos & 154500 & 61800 & 32682 & 21788 & 18540 & 12360 & 10894 & 6180 & 3090 \\
Máx. & $2,1 \mathrm{E}+07$ & $2,9 \mathrm{E}+06$ & $7,2 \mathrm{E}+05$ & $4,4 \mathrm{E}+05$ & $3,4 \mathrm{E}+05$ & $2,2 \mathrm{E}+05$ & $1,9 \mathrm{E}+05$ & $1,0 \mathrm{E}+05$ & $5,0 \mathrm{E}+04$ \\
Mín. & $1,7 \mathrm{E}+07$ & $2,1 \mathrm{E}+06$ & $6,4 \mathrm{E}+05$ & $3,9 \mathrm{E}+05$ & $3,1 \mathrm{E}+05$ & $2,0 \mathrm{E}+05$ & $1,7 \mathrm{E}+05$ & $9,1 \mathrm{E}+04$ & $4,5 \mathrm{E}+04$ \\
media & $1,9 \mathrm{E}+07$ & $2,5 \mathrm{E}+06$ & $6,7 \mathrm{E}+05$ & $4,1 \mathrm{E}+05$ & $3,2 \mathrm{E}+05$ & $2,0 \mathrm{E}+05$ & $1,8 \mathrm{E}+05$ & $9,4 \mathrm{E}+04$ & $4,6 \mathrm{E}+04$ \\
Des. P. & $6,5 \mathrm{E}+05$ & $1,4 \mathrm{E}+05$ & $1,6 \mathrm{E}+04$ & $8,6 \mathrm{E}+03$ & $6,8 \mathrm{E}+03$ & $4,2 \mathrm{E}+03$ & $4,8 \mathrm{E}+03$ & $2,0 \mathrm{E}+03$ & $1,0 \mathrm{E}+03$ \\
\hline D./M. \% & 3,40 & 5,61 & 2,40 & 2,08 & 2,13 & 2,07 & 2,63 & 2,12 & 2,17 \\
média T. & 122,81 & 39,69 & 20,63 & 18,95 & 17,34 & 16,48 & 16,63 & 15,26 & 15,01 \\
\hline
\end{tabular}


A Tabela 8 contém a série de testes variando o número de veículos entre 3.000 e 150.000. Em detalhe as linhas contem na ordem:

- O número de veículos considerados.

- O valor máximo encontrado em 10.000 tentativas casuais.

- O valor mínimo encontrado.

- O valor médio da distribuição.

- O desvio padrão da distribuição.

- A percentagem representada por o desvio padrão relativamente á média (rosa).

- O tempo médio que precisou cada veículo para chegar ao destino.

Figura 47: Amplitude das funções de otimização em proporção a própria media. Para fim de clareza as duas funções foram escaladas para ter média no 100.
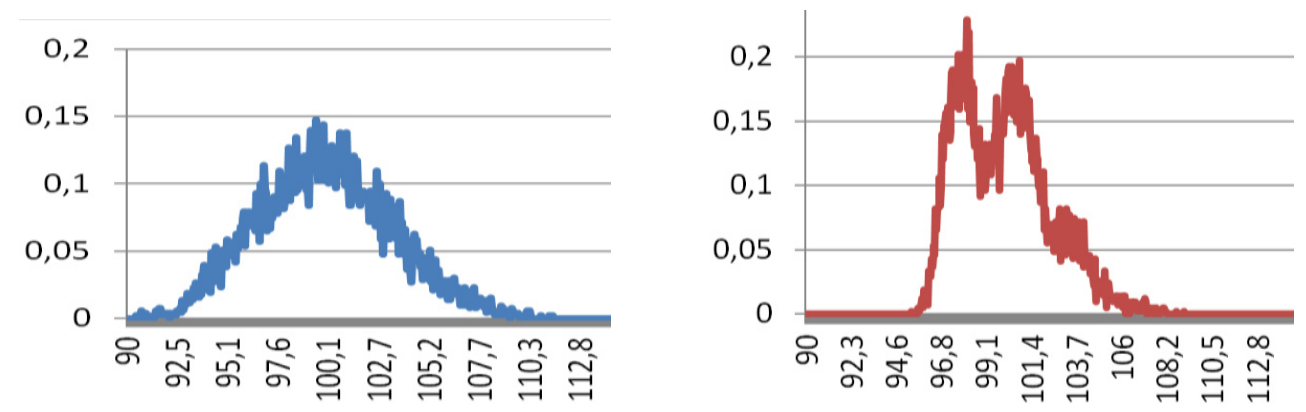

A Figura 47 mostra os perfis normalizados dos testes indicados com as mesmas cores na Tabela 8. Pode-se ver que o desvio padrão é sempre maior de $2 \%$. Quando a situação de trânsito piora este valor cresce (5\%) até que nas condições extremas todas as ruas fiquem saturadas e a possibilidade de melhoramento volte a ser menor. Este teste mostra a utilidade de uma simulação global mesmo limitada da aproximação dos blocos. As distribuições apresentadas tem uma extensão entre o $10 \%$ e o $20 \%$ da própria media, significando que através de uma recombinação dos planos operacionais locais é possível melhorar significativamente o desempenho total da rede. Este resultado depende também do tratamento dos dados iniciais como explicado na seção 5.7, no qual os diferentes tempos dos planos operacionais foram gerados modificando alternativamente em $5 \%$ os tempos originais.

\section{Teste 3: Mapeamento das rotas}

Nesta seção pode-se encontrar o mapeamento das rotas efetivas que os veículos seguirão. As rotas principais são as escolhidas em situação de estrada livre, mas 
com o crescimento engarrafamento do trânsito os veículos escolhem desvios não conhecidos com antecedência. Na Figura 48 são indicadas as entradas de veículos com os triângulos amarelos com o número de veículos por cada uma. As linhas azuis indicam os percursos efetuados tendo uma espessura proporcional ao número de passagens. Podem também ser reconhecidos os desvios saindo dos fluxos principais e caracterizados por linhas mais finas. Em detalhe a partir do fluxo de cerca 3000 veículos, que representa a situação de engarrafamento mais intensa, se destacam vários caminhos alternativos que atraem uma parte significativa do próprio fluxo.

Figura 48: Rotas efetivas dos veículos.

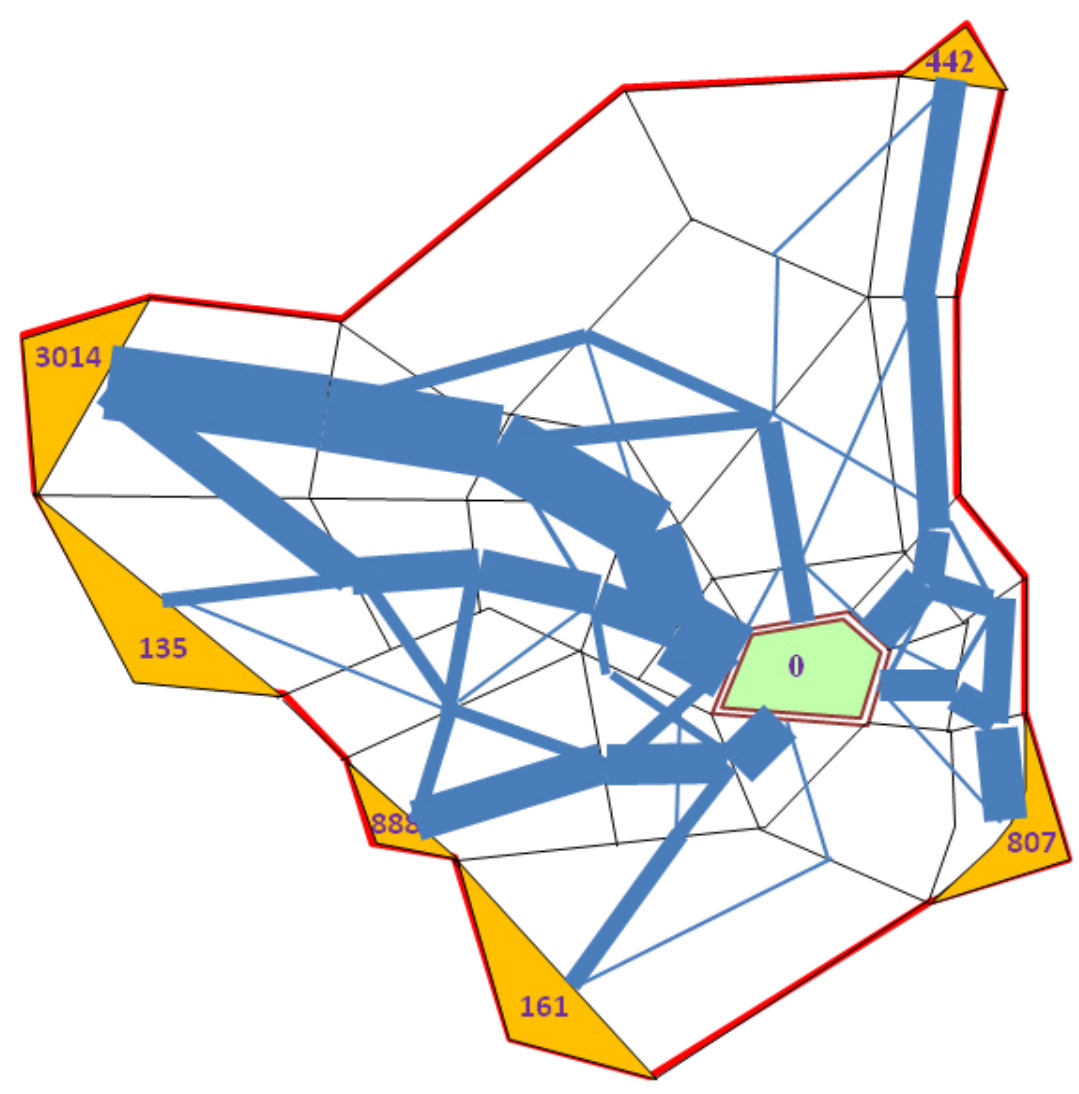

\section{Teste 4: Processo de otimização}

Nesta seção são apresentados resultados ligados ao desempenho do método de otimização. Os testes foram efetuados com diferentes níveis de trânsito, condição de estrada livre (com cerca de 5.000 veículos), condição de meio trânsito ( 25.000 veículos) e condição de trânsito muito intenso ( 50.000 veículos). Nas Figuras 49a e $49 \mathrm{~b}$ são representados com setas os direcionamento favorecidos em cada bloco das 
melhores soluções encontradas, pelo método de busca, nas condições de trânsito livre e de trânsito muito intenso. Em cada bloco a seta indica um a direção favorecida pelo plano operacional local escolhido. Os tempos dos arcos que trazem veículos na mesma direção foram diminuídos em 5\%, no contrario todos outros arcos do mesmo bloco sofreram um aumento no tempo de transito de 5\%. Os blocos marcados com o circulo (sem seta) não sofreram alguma alteração nos tempos dos arcos, mantendo os valores originais (plano operacional local balanceado). No primeiro caso houve pouco uso dos desvios, de modo que a solução ótima favorece os fluxos diretamente na direção do ponto de atração; contrariamente, na Figura 49b, os círculos azuis evidenciam que, em caso de trânsito intenso, o melhor desempenho se obtém limitando a velocidade e estimulando os motoristas a desviar nos percursos alternativos.

\section{Figura 49a: Solução ótima encontrada em situação de trânsito leve.}

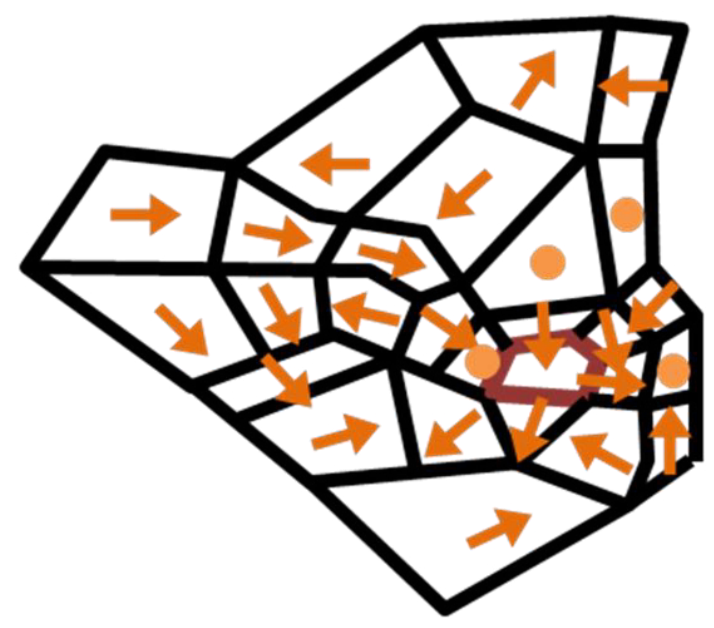

Figura 49b: Solução ótima encontrada em situação de trânsito muito intenso.

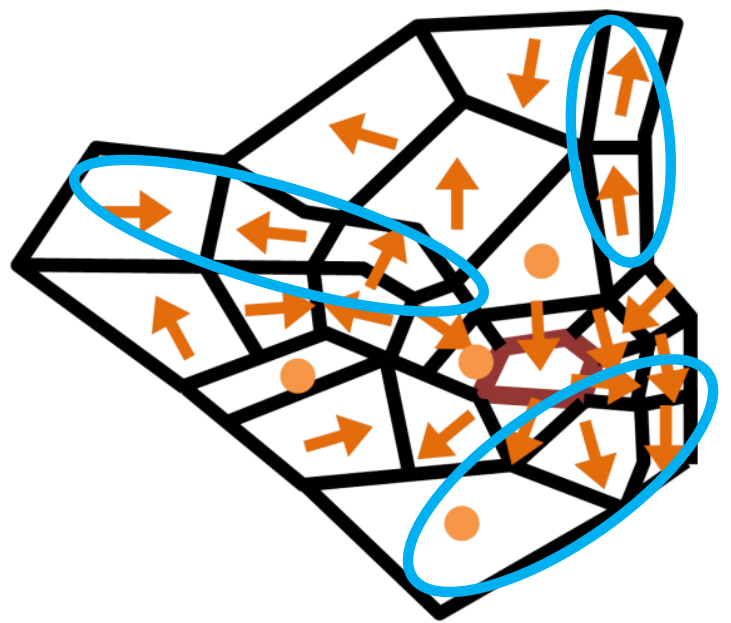

Os gráficos das Figuras 50a, 50b e 50c mostram o típico andamento descendente dos algoritmos de busca. Cada gráfico contém quatro simulações sendo os grupos de linhas mais altas as medias das gerações e as mais baixas os melhores valores encontrados ao longo da simulação. As três figuras se referem nos três níveis de trânsito discutidos no inicio da seção. Como falado em outras seções, os quatro tempos de travessia dos blocos ao variar do plano operacional local tem uma variabilidade de 10\% (+ ou - 5\%). Confrontando o valor médio da primeira geração (média da função) com a melhor solução encontrada se mede um ganho em volta de $5 \%$ na condição de estrada livre, já que as dinâmicas de desvios tem pouca 
influência. Ao crescer do número de veículos, as dinâmicas ficam mais complexas e o efeito dos desvios permite um ganho de até $7 \%$ sobre a média da função.

Intuitivamente, impostando manualmente os genes na forma de favorecer a direção do ponto de atração em cada bloco, o valor de fitness esperado não deveria ser muito diferente do valor mínimo encontrado. Esta intuição traz beneficio no caso de trânsito moderado a causa da reduzida complexidade das dinâmicas, mas no caso de trânsito intenso a solução intuitiva revela um desempenho muito pior do que melhor encontrada através da otimização. Os dados numéricos medem uma diferença inferior a $1 \%$ no caso de estrada livre e uma diferença maior que $5 \%$ no caso de trânsito intenso. Considerando que as soluções ótimas desviam de cerca de $5 \%$ da média da função se percebe como a solução intuitiva é uma boa escolha no primeiro caso, mas ao contrario, quando o trânsito é caótico, tendo esta um desempenho parecido com a média da função de otimização.

Figura 50a: Processo evolutivo tendo uma instancia composta de cerca 5.000 veículos (estrada livre).

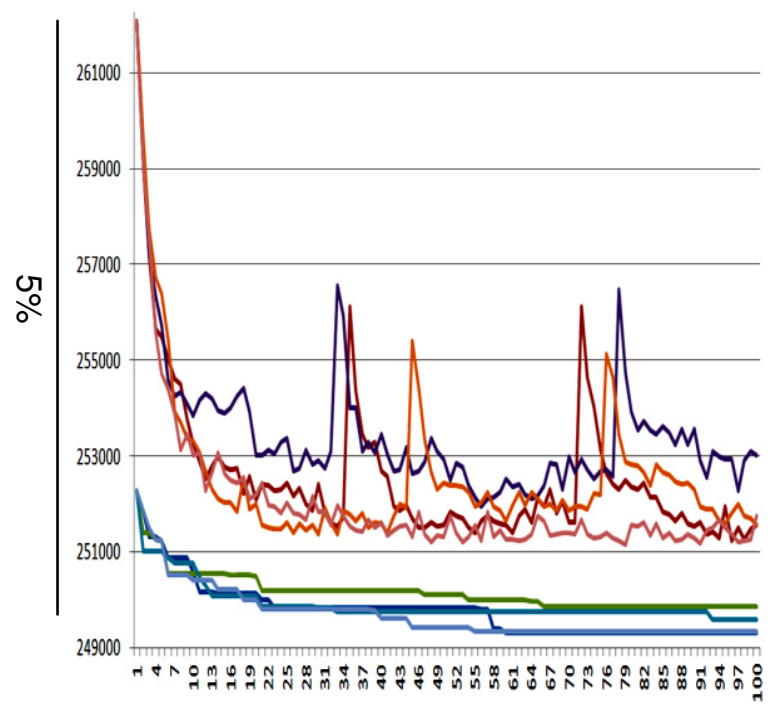

Figura 50b: Processo evolutivo tendo uma instancia composta de cerca 25.000 veículos (pouco trânsito).

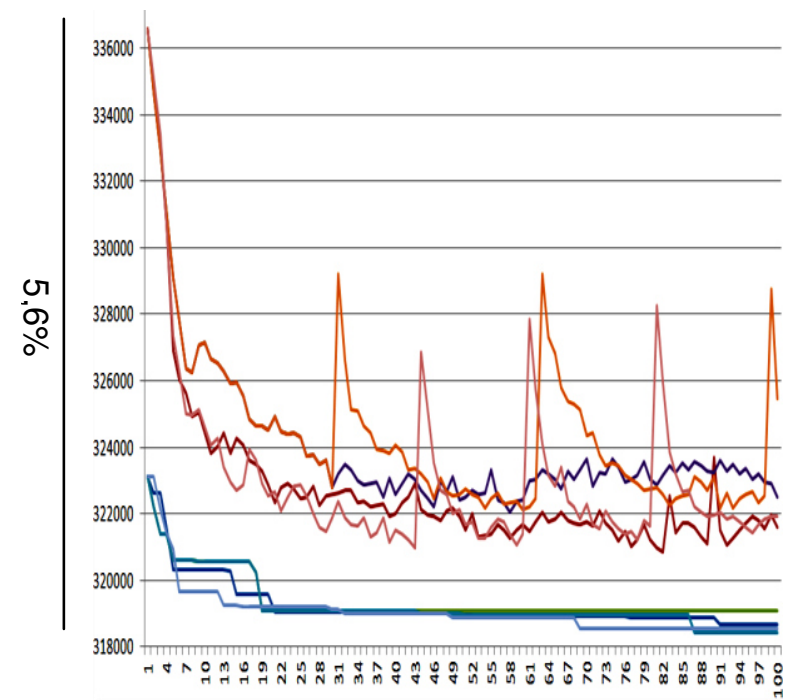


Figura 50c: Processo evolutivo tendo uma instancia composta de cerca 50.000 veículos (trânsito caótico).

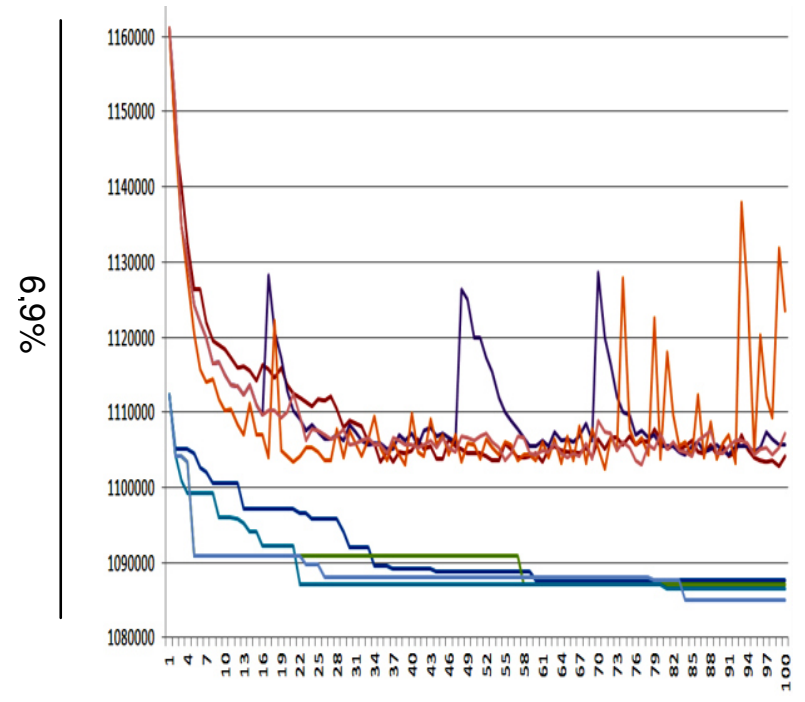

Os testes das Figuras 50 são resultados de quatro processos de otimização, na mesma instância, mudando os parâmetros do A.G. Em detalhe foram usadas diferentes taxas de mutação e limites de aceitação dos indivíduos pais. Em alguns testes foi usado um sistema anticiclo que age introduzindo um grande número de mutações extras quando houve várias gerações sem trazer alguma melhoria, indicando assim a presença de um mínimo local no qual o sistema estava ficando preso. A intervenção deste recurso é bem visível nos valores médios das gerações quais tenham um repentino aumento devido a perda das informações que levaram precedentemente $\mathrm{o}$ algoritmo a encontrar a solução mínima corrente. 


\section{Capítulo 9 - Conclusões}

O Trabalho, inicialmente pensado para ter um caráter mais prático, assumiu na verdade uma conotação bastante teórica que deu a possibilidade de pesquisar e reunir ideias de diferentes setores da literatura consultada. Partindo da ideia inicial de otimizar os fluxos direcionados ao estádio de Itaquera, ao longo da pesquisa a atenção passou a focalizar o problema geral de enfrentar simulações de trânsito em territórios grandes. Neste ponto foi preciso gerar um teste capaz de avaliar os pontos do domínio de otimização de modo rápido e mantendo algumas analogias com a realidade. Mesmo que o modelo seja muito pobre em detalhes, abstraindo a dinâmica dos veículos para garantir a velocidade de cálculo necessária, este assume como dados iniciais planos operacionais localmente ótimos. Enfim este teste é o simulador apresentado, o qual trabalha sobre os dados dos blocos que contem os resultados das simulações locais. O cálculo real do plano operacional dos bairros em volta do estádio de Itaquera necessita assim primeiro de uma série de estudos locais que representariam um trabalho excessivo para um projeto de mestrado e com pouca contribuição para o caráter teórico que o trabalho estava assumindo.

O trabalho se completa com a implementação do simulador de bloco e a simulação da área de São Paulo em volta do estádio de Itaquera. Como esclarecido em várias seções do texto, os dados iniciais foram encontrados sem efetuar as simulações locais, primeiro passo do processo hierárquico proposto. Assim este estudo tem caráter de exemplo aplicativo, mas sem chegar a real solução de plano operacional ótimo. Os resultados obtidos nos testes mostram os requisitos do simulador necessários para o problema de planejamento global das metrópoles. Analisando com mais detalhe, a primeira propriedade do simulador apresentada é a velocidade do processamento que se revela compatível com o tamanho dos domínios gerados da consideração global das metrópoles. No segundo teste se mostra como os valores de fitness das funções de otimização obtidas variam em um intervalo suficientemente amplo em relação à própria média. Se deduz disso que o uso do novo nível hierárquico proposto, voltado à otimização global, pode garantir uma margem apreciável de melhoramento. Por fim os critérios de desvio utilizados geram padrões de rota qualitativamente adequados, necessitando de um processo de 
calibração especifico para os usuários da situação simulada. $O$ trabalho assim se conclui concretizado o desenvolvimento do simulador e deixando aberta a possibilidade de novos estudos voltados à geração da interface para a recuperação automática dos dados iniciais. Por contra do bom desempenho do simulador proposto, um próximo trabalho será dependente de outros fatores.

É preciso lembrar que mesmo gerando a interface para a recuperação dos dados, as simulações locais que compõem o primeiro nível hierárquico também precisam de dados iniciais complexos. Como discutido ao longo do texto existem vários jeitos de obter dados a redor do trânsito, implantando novas tecnologias ou rastreando sinais de vários aparelhos privados. Todas comportam problemas de ordem organizacional ou econômica, os primeiros no caso do uso dos dados privados em conformidade com as normas nacionais, os segundos no caso de construção de um sistema dedicado.

Um fator ainda mais importante para ser avaliado é a competitividade das outras tecnologias disponíveis. Em detalhe, as técnicas baseadas em sensores e sistemas inteligentes comprovam desempenhos melhores, comportando por outro lado o investimento de implantação dos sensores. Considerando que como discutido também a integração do sistema proposto em uma ferramenta híbrida ou com bancos de dados, para ser criado, envolve gastos e tempo de modo que a escolha das novas tecnologias constitui uma alternativa ainda mais tentadora.

Uma última consideração em relação ao uso da otimização de trânsito é relativa aos usuários e suas tendências. Nas grandes cidades do mundo as pistas não são suficientes para atender a um trânsito baseado em veículos particulares de toda a população. Todas as metrópoles oferecem linhas publicas que garantem a mobilidade absorvendo grande parte da movimentação diária da população. O limite mínimo de capacidade das linhas metropolitanas é de 24.000 pessoas/h (norma UNI 8379-2000 anexo B) equivalente a uma pista de dez faixas, sendo que a capacidade máxima destas é de cerca 2.300 veículos/faixa/hora. (Cristalli, 2010)

A população é um organismo vivo que reage às mudanças, encontrando uma situação de equilíbrio. No contexto do trânsito cada individuo pode escolher entre carro ou ônibus, de modo que a razão de trânsito particular em uma cidade se ajusta a um valor de equilíbrio sensível às mudanças da rede. Na prática, tendo uma 
cidade com muito trânsito e assumindo construir novas infraestruturas que duplicam a capacidade global das vias, o resultado após algum tempo não será um ganho tão acentuado na velocidade de trânsito porque um número maior de usuários será tentado a usar o carro. A condição do transporte público melhoraria um pouco a causa do decremento dos usuários enquanto que o trânsito voltaria em uma condição parecida a de antes, restaurando o equilíbrio. Em geral a disparidade de ocupação de espaço comportada por uma pessoa (caso do transporte publico) ou por um veículo (caso de uso do carro particular) faz com que o transporte público tenha uma menor sensibilidade que o particular à migração de usuários entre uma e outra categoria. Estas considerações deixam claro que a mobilidade só pode ser melhorada substancialmente através de uma melhor percepção do transporte publico pelos cidadãos. Este fator pode ser conseguido através de vários canais conjuntamente, a partir da construção e fortalecimento real das linhas públicas, ao conforto na sua utilização até a propaganda que mira formar uma consciência coletiva de que um transporte eficiente traz benefícios para todos. Por fim, as otimizações do trânsito oferecem uma contribuição neste processo geral, mantendo assim a importância de sua contribuição para a qualidade de vida das cidades, evitando gastos e transtornos desnecessários. 



\section{Referência Bibliográfica}

Adorio, E. P. MVF - Multivariate test functions library in $\mathbf{c}$ for unconstrained global optimization. Filippine: University of the Philippines Diliman, 2005.

Burghout, W. Hybrid microscopic-mesoscopic traffic simulation. Stockholm: Royal Institute of Technology, 2004.

Castanho, A. D., Artaxo, P. Wintertime and summertime São Paulo aerosol source apportionment study. São Paulo: Universidade de São Paulo, 2001.

Cook, S. The P versus NP problem. USA: Clay Mathematics Institute, 2000.

Crisalli, U. Teoria e tecnica della circolazione: teoria del deflusso ininterrotto. Roma: Univesidade de Roma, 2010.

Crisci, M. Sistemi giornalieri urbani di roma: un'ipotesi di definizione. Roma: Universidade La Sapienza, 2002.

De Giovanni, L. Metodi e modelli per l'ottimizzazione combinatoria; metodi euristici di ottimizzazione combinatoria. Padova: Universidade dos estudos de Padova, 2008.

Deganzo, C. F. The cell transmission model: A simple dynamic rapresentation os highway traffic. Barkeley: Universidade da California, 1993.

Della Rossa, F.; Tomarelli, F. (2008) Analisi di traffico veicolare report. Milão: Politécnico de Milão.

Halkias, J. A. Traffic Signal Control Systems. USA: Federal Highway Administration, 1997.

Hess, S. Intelligent Transport Systems. France: ETSI, 2009. Disponivel em: <http://www.etsi.org/images/files/ETSITechnologyLeaflets/Intelligent TransportSystems.pdf>. Acesso em: 10/2013.

Hickman, L. Welcome to the world's worst traffic jam. The Guardian, 23/08/10. 
Litman, T. A.; Doherty, E. Transportation Cost and Benefit Analysis Techniques, Estimates and Implications. Executive Summary. Victoria: Victoria Transport Policy Institute, 2011.

Martins, B.; Reinhard, M.; Reinhart, K. Model of Vehicular Traffic by Hilliges and Weidlich Revisited. German: Rostock University, 2013.

Monticone, E. A.; Amaldi, E. Meta euristica per un problema di instradamento per I Erbolario s.r.I. Milão: Politécnico de Milão, 2008.

Mugnela, B. S., Netto, M. L. Genpolis: prototipagem e aplicação de um simulador de trânsito voltado para otimização de sinalização semafórica por meio de algoritmos genéticos. São Paulo: EP-USP, 2012.

Norberto, G. D. São Paulo em indicadores e metas. São Paulo, 2010. Disponivel em: <http://www.nossasaopaulo.org.br/portal/files/saopaulo_indicadores_metas.pdf>. Acesso em: 9/2013.

Perna, C.; Sacone, S. Modellistica e simulazione del comportamento del traffico in intersezioni stradali urbane. Savona: Universidade de Genova, 2008.

Pescaru, D.; Curiac, D. Ensemble Based Traffic Light Control for City Zones Using a Reduced Number of Sensors. Romania: Universidade de Timişoara, 2014.

Semple, J. Frota brasileira de veículos cresceu $121 \%$ nos últimos dez anos.

Automotive Business 22/02/12. Disponivel em: <http://www.automotivebusiness .com.br/artigosecolunistas.aspx?id_artigo=538>. Acesso em: 5/2013.

The great crawl of China. The Economist, 26/08/10.

Università degli studi di Genova, S. A. Modellistica, Simulazione e Previsione a Breve Termine del Comportamento Dinamico del Traffico su Tratti Autostradali. Disponivel em: <http://www.dist.unige.it/ccontheweb/curriculum/MyPoster.pdf>. Acesso em: 01/2013.

Velázquez, G. P. Selective search for global optimization of zero or small residual least-squares problems, a numerical study. Houston: Rice University, 1999. 
Visitesaopaulo.com. Dados da cidade Seção: Transportes, Acessibilidade e Meio Ambiente, 2013. Disponivel em: <http://visitesaopaulo.com/dados-da-cidade.asp>. Acesso em: 1/2014.

Watts, J. Gridlock is a way of life for Chinese. The Guardian, 24/08/10.

Wines, M. China's growth leads to problems down the road. New York Times, 27/08/10.

Yousef, K.; Al-Karaki1, J.; Shatnawi, A. intelligent traffic light flow control system using wireless sensors networks. Journal of Information Science and Engineering , n.26, p. 753-768, 2010.

Zuben, P. V. Algoritmos Genéticos. Campinas: Unicamp, 2000.

\section{Referência Complementar}

Valedigi. Traffico record in Cina: $100 \mathrm{~km}$ di coda. ADS-News, 2010. Disponivel em: $<$ http://www.ads-news.com/traffico-record-in-cina-100-km-di-coda/772/>. Acesso em: $5 / 2013$

Agência Mobilidade Roma. Disponivel em: <http://www.agenziamobilita.roma.it/ progetti-della-mobilita/intersezione-bufalotta-gronchi-fucini.html>. Acesso em: 5/2014

Redas Italia, Aimsun 2012. Disponivel em <http://www.redasitalia.it/Spg/pt03.html>. Acesso em: 01/2013.

De Mitri, M. Conteudo vídeo, 2013. Disponivel em: <http://www.marcodemitri.it>. Acesso em: 5/2013.

Dellenback, S. Advanced traffic management systems (ATMS) Texas: Southwest Research Institute, 2013. Disponivel em: <http://www.swri.org/3pubs/ brochure/d10/ATMS/ATMSflyer.pdf>. Acesso em:8/2013.

Fenabrave. Resumo mensal 08/2012. Disponivel em: <http://issuu.com/fenabrave /docs/2012_08_2x?e=6659190/1383629\#search >. Acesso em: 5/2013 
Governo Francês. Grand Paris. Disponivel em: <http://www.territoires.gouv.fr /spip.php?rubrique19>. Acesso em: 01/2013.

Galdino, M. Um passo pra trás para dar dois passos para frente. Blog prafalardecoisas. Disponivel em: <http://prafalardecoisas.wordpress.com/2010/08/24/ um-passo-pra-tras-para-dar-dois-passos-para-frente/>. Acesso em: 8/2013.

Galli, M.; Pari, M. Modelli macroscopici di traffico veicolare. 2010. Disponivel em: <http://matteogalli.wordpress.com/2010/01/29/modelli-macroscopici-di-trafficoveicolare/> e <http://michelepari.wordpress.com/2010/08/16/modelli-macroscopici-ditraffico-veicolare-seconda-parte/>. Acesso em: 5/2013.

Giovanelli, C. Quantos veículos circulam por São Paulo ao certo? Veja São Paulo, Especial Trânsito. 01/04/11. Disponivel em: <http://vejasp.abril.com.br /materia/carros-em-sao-paulo>. Acesso em: 5/2013.

Frota de veículos nas capitais quase dobra em 10 anos. Globo Epoca Negocios 2012.

<http://sfpark.org/>. Acesso em: 8/2013.

<http://www.aimsun.com/wp/>. Acesso em: 9/2013.

<http://www.paramics.it/micro.htm>. Acesso em: 9/2013.

<http://www.portal2014.org.br/andamento-obras/82/Intervencoes+Viarias+em+ Itaquera+Entorno.html>. Acesso em: 11/2013.

Quarteroni, A. SATW. Berna 2010. Disponivel em: <http://www.satw.ch/ veranstaltungen/zurueckliegende/Quarteroni_SATW_Bern.pdf>. Acesso em: 5/2013.

TransModeler. Caliper 2008. Disponivel em: <http://www.caliper.com/PDFs /TransModeler\%20Brochure.pdf>. Acesso em: 10/2013.

Toyota Motor Corporation. Toyota global newsroom, 03/09/09. Disponivel em <http://www2.toyota.co.jp/en/news/09/09/0903.html>. Acesso em: 01/2013. 


\section{GLOSSÁRIO}

Agregado/agregação: Por 'modelo agregado em blocos' ou 'agregação da rede viária em blocos' se entende um modelo no qual as ruas e os cruzamentos não são representados diretamente. No modelo comparece o elemento bloco como porção mínima da rede viária. O bloco representa assim um conjunto de ruas e cruzamentos próximos, os quais no modelo são agregados em um único elemento (um bloco).

Erro de borda: $\quad$ Erros gerados por modelos que internamente ao domínio apresentam valores exatos, mas na borda geram erros provenientes dos dados de borda. Isso acontece todas as vezes que um dado é tratado em média ignorando as oscilações dele.

Fluxos principais: Fluxos de maior porte direcionados ao ponto de atração percorrendo as rotas principais.

Função de Fitness: Função de otimização na terminologia especifica dos A.G. Enquanto as soluções são interpretadas como indivíduos, o valor que avalia o quão boa é a solução ganha o nome de Fitness do individuo, com o sentido de adaptação ao ambiente.

Função de Otimização: Função que retorna um valor numérico a partir das características de uma solução proposta. Este valor inclui custos, materiais, recursos, sendo assim uma solução tanto mais desejada quanto menor for este valor.

Ponto de atração: Ponto no qual se dirige o maior fluxo de veículos em um particular momento. (estádio, evento público, praia...)

Processos exatos: Termo usado em pesquisa operacional para definir os processos que chegam sempre à solução ótima. 
Rotas internas: Rotas que trazem os veículos que partem já no interior do mapa até uma rota principal o diretamente no ponto central. Também seguem os percursos mais rápidos calculados no caso de estrada livre.

Rotas principais: Rotas que trazem os veículos que entram da margem do mapa até o ponto central em caso de ausência de trânsito, por isso são poucas e seguem as avenidas maiores. 


\section{ANEXOS}

\section{A1 Mercado da Simulação de Trânsito}

A seguir são apresentados exemplos de pacotes de software usados para simulação de trânsito.

A1.1 Macroscópicos

Cube Voyager

OREMS

A1.2 Mesoscópicos

Cube Avenue

Tracks
Emme

OmniTRANS

TransCAD

TransModeler

PTV VISION

\section{A1.3 Microscópicos}

ARCADY

DRACULA

Quadstone Paramics

SimTraffic

TRITONE_(simulazione)

PARAMICS
TRANSIMS

Dynameq

DYNASMART

TransModeler
DynusT

Mezzo
CORSIM

MATSim

Sidra Trip

TransModeler

PTV VISSIM 


\section{A1.4 Hybrid}

Aimsun

micro-meso-macro

S-Paramics

micro-macro

TransModeler

micro-meso-macro

Synchro Studio

macro+otimização

MiMe

micro-meso

(Wikipedia: Traffic simulation) (TransModeler)

\section{A2 Estruturas de dados}

\section{A2. 1 Prin}

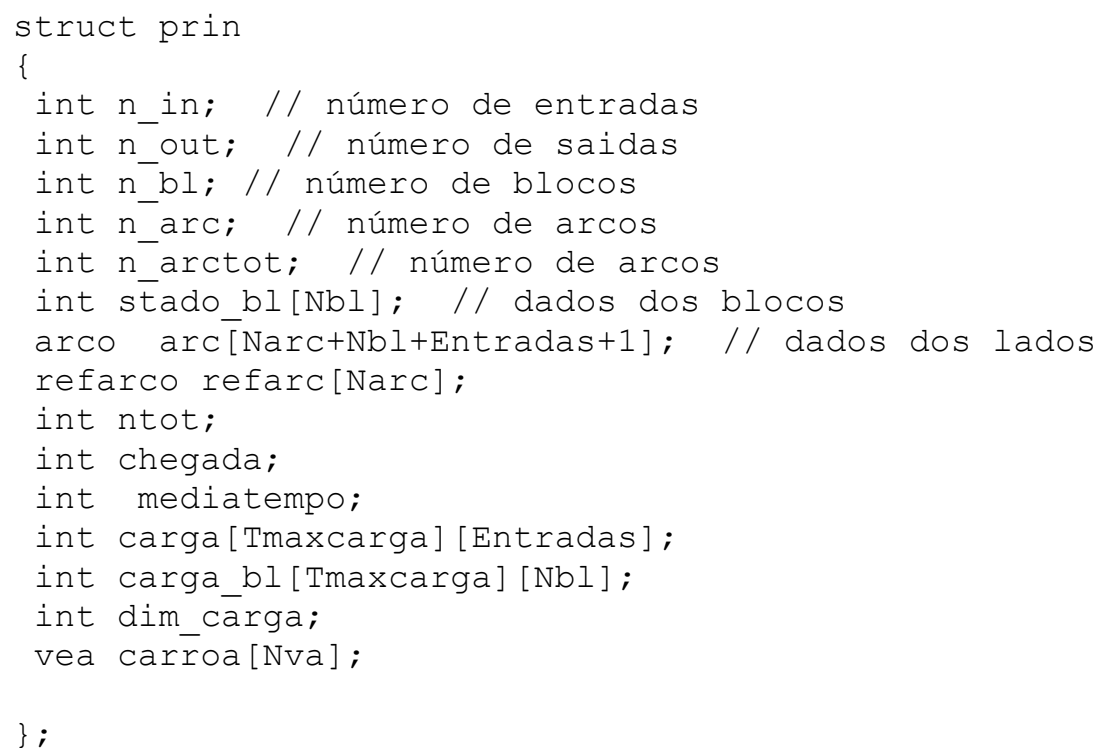




\section{A2.2 Populacao}

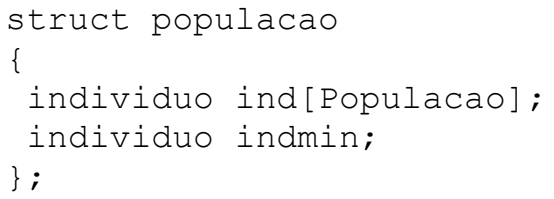

\section{A2.3 Arco e Refarco}

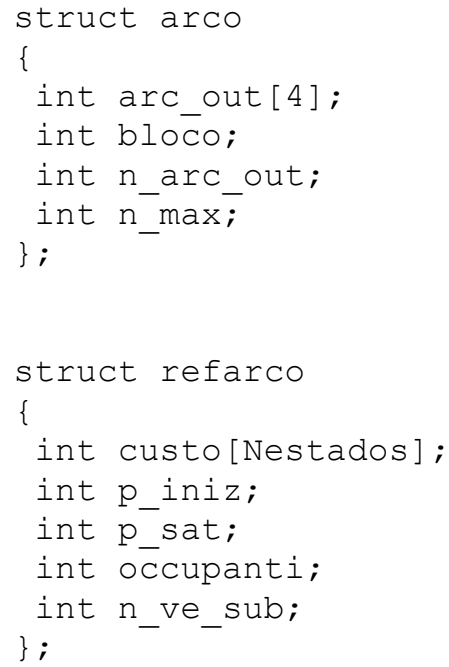

\section{A2.4 Vea}

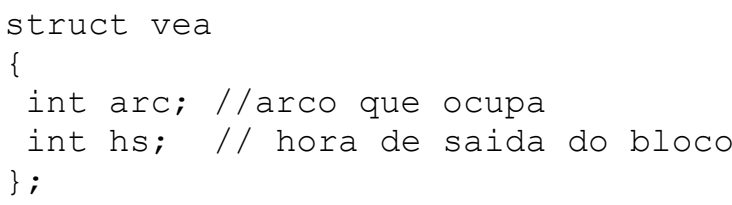

\section{A2.5 Individuo}

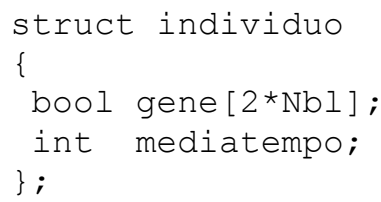




\section{A3 Arquivos dos dados iniciais}

\section{A3.1 load_data_map}

File: load_data_map

Documento de carga do simulador

Neste documento serão leitos somente os números. Palavras e outros símbolos podem ser inseridos arbitrariamente.

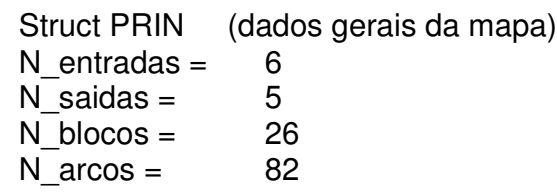

Vector Arcos prin.ar[] (struct Arcos)

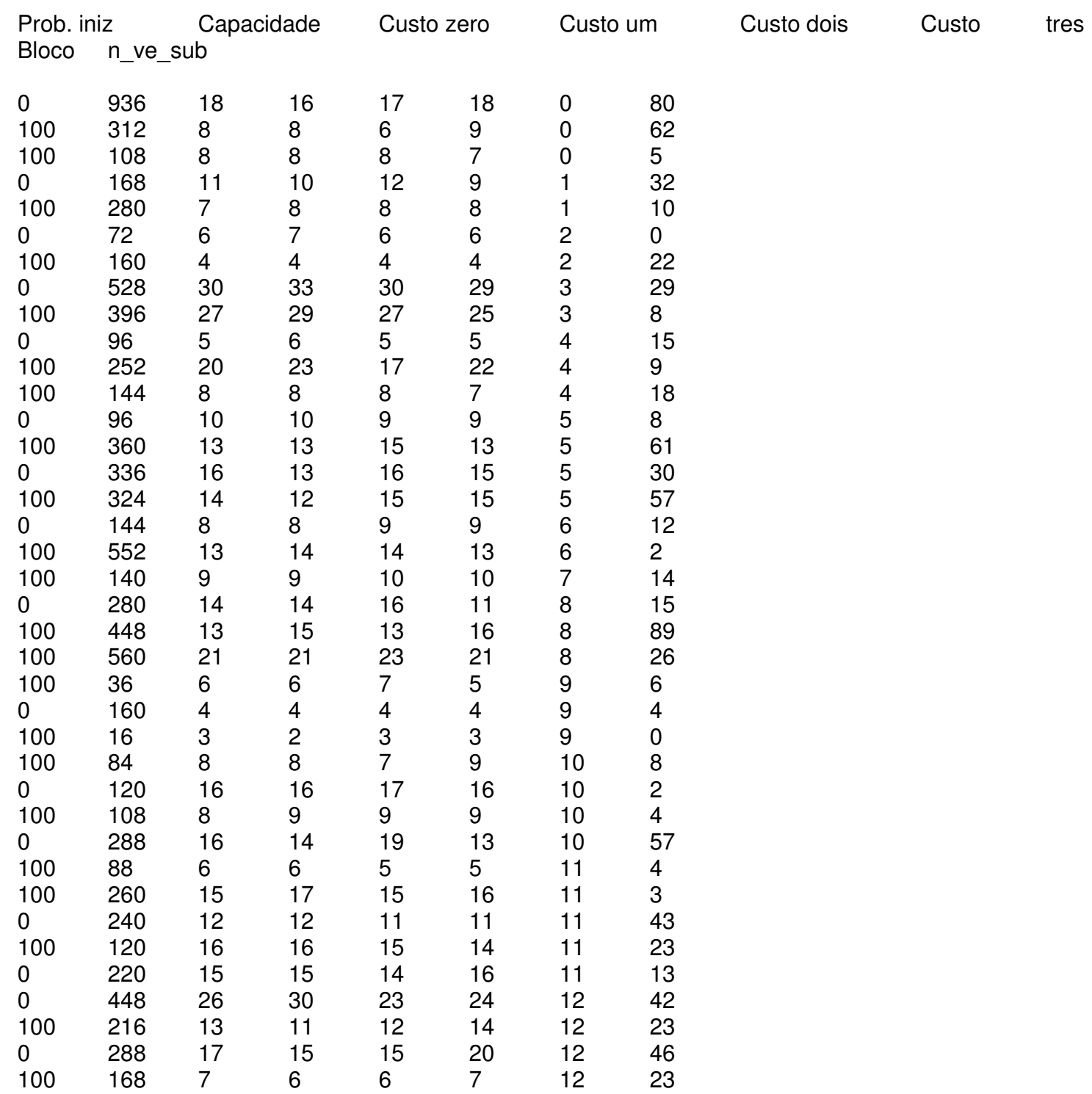




$\begin{array}{llllllll}100 & 192 & 8 & 9 & 8 & 9 & 12 & 8 \\ 100 & 224 & 9 & 9 & 10 & 9 & 13 & 38 \\ 0 & 224 & 11 & 13 & 10 & 10 & 13 & 43 \\ 100 & 280 & 14 & 12 & 13 & 15 & 13 & 14 \\ 100 & 224 & 9 & 8 & 10 & 9 & 14 & 41 \\ 0 & 288 & 13 & 11 & 13 & 11 & 15 & 30 \\ 100 & 280 & 18 & 19 & 19 & 20 & 15 & 32 \\ 0 & 360 & 30 & 29 & 28 & 31 & 15 & 13 \\ 100 & 392 & 20 & 22 & 17 & 16 & 15 & 67 \\ 100 & 320 & 21 & 22 & 19 & 20 & 15 & 32 \\ 0 & 160 & 13 & 13 & 15 & 14 & 16 & 21 \\ 100 & 336 & 10 & 9 & 9 & 8 & 16 & 41 \\ 0 & 32 & 6 & 5 & 5 & 5 & 16 & 4 \\ 100 & 200 & 16 & 17 & 14 & 16 & 16 & 24 \\ 100 & 240 & 11 & 10 & 12 & 13 & 17 & 27 \\ 100 & 120 & 10 & 10 & 11 & 10 & 17 & 8 \\ 100 & 304 & 6 & 5 & 7 & 6 & 17 & 24 \\ 100 & 480 & 18 & 17 & 19 & 17 & 18 & 61 \\ 100 & 448 & 20 & 18 & 22 & 21 & 18 & 17 \\ 0 & 96 & 13 & 12 & 13 & 12 & 18 & 5 \\ 0 & 224 & 17 & 19 & 19 & 16 & 18 & 11 \\ 100 & 168 & 5 & 5 & 5 & 5 & 19 & 33 \\ 100 & 168 & 7 & 7 & 8 & 7 & 19 & 27 \\ 0 & 80 & 6 & 6 & 7 & 5 & 19 & 15 \\ 100 & 80 & 6 & 5 & 6 & 6 & 19 & 2 \\ 100 & 120 & 3 & 3 & 2 & 2 & 20 & 20 \\ 100 & 80 & 2 & 2 & 2 & 2 & 20 & 12 \\ 0 & 120 & 3 & 2 & 3 & 2 & 20 & 4 \\ 100 & 96 & 10 & 11 & 8 & 8 & 21 & 4 \\ 100 & 192 & 3 & 3 & 3 & 2 & 21 & 7 \\ 100 & 64 & 6 & 7 & 6 & 7 & 21 & 9 \\ 100 & 96 & 6 & 7 & 6 & 7 & 22 & 7 \\ 0 & 32 & 3 & 3 & 3 & 3 & 22 & 1 \\ 0 & 32 & 6 & 7 & 5 & 6 & 22 & 6 \\ 100 & 32 & 6 & 7 & 7 & 6 & 23 & 4 \\ 100 & 160 & 4 & 5 & 4 & 5 & 23 & 15 \\ 100 & 80 & 2 & 2 & 2 & 1 & 23 & 0 \\ 0 & 80 & 2 & 2 & 2 & 2 & 23 & 12 \\ 100 & 72 & 10 & 9 & 10 & 9 & 24 & 6 \\ 0 & 16 & 6 & 6 & 6 & 5 & 24 & 3 \\ 100 & 24 & 4 & 3 & 4 & 4 & 24 & 4 \\ 100 & 40 & 5 & 5 & 5 & 4 & 24 & 5 \\ 100 & 24 & 1 & 1 & 1 & 1 & 25 & 1 \\ 100 & 128 & 10 & 9 & 11 & 8 & 25 & 17\end{array}$

n_ar_seg arcos seguidos (o primeiro arco escreto é o arco principal, o com prob_iniz de cento)

$\begin{array}{llll}2 & 8 & 7 & \\ 2 & 11 & 10 & \\ 2 & 13 & 12 & \\ 2 & 15 & 14 & \\ 2 & 17 & 16 & \\ 3 & 20 & 19 & 21 \\ 1 & 22 & & \\ 2 & 24 & 23 & \\ 2 & 24 & 23 & \\ 1 & 25 & & \\ 2 & 27 & 26 & \\ 2 & 32 & 33 & \\ 2 & 29 & 30 & \\ 2 & 34 & 35 & \\ 2 & 36 & 40 & \\ 2 & 42 & 41 & \\ 2 & 37 & 38 \\ 2 & 37 & 38\end{array}$




\begin{tabular}{|c|c|c|c|}
\hline 1 & 9 & & \\
\hline 2 & 46 & 47 & \\
\hline 2 & 44 & 43 & \\
\hline 2 & 46 & 47 & \\
\hline 1 & 49 & & \\
\hline 3 & 56 & 55 & 57 \\
\hline 2 & 53 & 52 & \\
\hline 1 & 63 & & \\
\hline 2 & 70 & 72 & \\
\hline 2 & 70 & 72 & \\
\hline 2 & 83 & 84 & \\
\hline 1 & 71 & & \\
\hline 2 & 83 & 84 & \\
\hline 1 & 86 & & \\
\hline 1 & 88 & & \\
\hline 1 & 88 & & \\
\hline 1 & 86 & & \\
\hline 1 & 87 & & \\
\hline 1 & 87 & & \\
\hline 1 & 73 & & \\
\hline 1 & 87 & & \\
\hline 1 & 73 & & \\
\hline 1 & 60 & & \\
\hline 1 & 48 & & \\
\hline 1 & 60 & & \\
\hline 1 & 18 & & \\
\hline 1 & 18 & & \\
\hline 1 & 59 & & \\
\hline 1 & 45 & & \\
\hline 1 & 59 & & \\
\hline 2 & 51 & 50 & \\
\hline 1 & 58 & & \\
\hline 3 & 62 & 64 & 65 \\
\hline 1 & 58 & & \\
\hline 3 & 62 & 64 & 65 \\
\hline 3 & 62 & 64 & 65 \\
\hline 1 & 54 & & \\
\hline 1 & 66 & & \\
\hline 1 & 61 & & \\
\hline 1 & 66 & & \\
\hline 2 & 67 & 68 & \\
\hline 2 & 67 & 68 & \\
\hline 2 & 67 & 68 & \\
\hline 3 & 76 & 77 & 78 \\
\hline 3 & 76 & 77 & 78 \\
\hline 1 & 69 & & \\
\hline 1 & 28 & & \\
\hline 1 & 74 & & \\
\hline 1 & 74 & & \\
\hline 1 & 39 & & \\
\hline 1 & 74 & & \\
\hline 2 & 80 & 82 & \\
\hline 2 & 80 & 82 & \\
\hline 1 & 31 & & \\
\hline 1 & 0 & & \\
\hline 1 & 0 & & \\
\hline 1 & 0 & & \\
\hline 1 & 0 & & \\
\hline 1 & 75 & & \\
\hline 1 & 79 & & \\
\hline 1 & 0 & & \\
\hline 1 & 0 & & \\
\hline 1 & 0 & & \\
\hline 1 & 85 & & \\
\hline 1 & 0 & & \\
\hline 1 & 81 & & \\
\hline 1 & 0 & & \\
\hline
\end{tabular}




$\begin{array}{ll}1 & 0 \\ 1 & 0 \\ 1 & 0\end{array}$

\section{A3.2 load_onda_carga}

Documento de carga do simulador Neste documento serão leitos somente os números. Palavras e outros símbolos podem ser inseridos arbitrariamente.

Comprimento da carga $=$

Carga das entradas

\begin{tabular}{llrlll}
\multicolumn{6}{l}{ Carga das entradas } \\
0 & 16 & 32 & 24 & 28 & 0 \\
0 & 18 & 44 & 44 & 20 & 0 \\
0 & 16 & 44 & 38 & 32 & 0 \\
0 & 14 & 38 & 40 & 30 & 0 \\
0 & 22 & 34 & 26 & 30 & 0 \\
0 & 14 & 28 & 30 & 28 & 0
\end{tabular}

Carga dos blocos

$\begin{array}{llllll}0 & 0 & 1 & 1 & 0 & 0 \\ 0 & 0 & 0 & 0 & 0 & 0 \\ 0 & 1 & 2 & 2 & 1 & 0 \\ 0 & 0 & 0 & 0 & 0 & 0 \\ 0 & 0 & 1 & 1 & 0 & 0 \\ 0 & 3 & 7 & 7 & 7 & 0 \\ 0 & 1 & 1 & 1 & 1 & 0 \\ 0 & 0 & 0 & 1 & 0 & 0 \\ 0 & 0 & 0 & 1 & 0 & 0 \\ 0 & 0 & 1 & 1 & 0 & 0 \\ 0 & 0 & 1 & 1 & 1 & 0 \\ 0 & 0 & 0 & 0 & 0 & 0 \\ 0 & 0 & 1 & 1 & 0 & 0 \\ 0 & 1 & 2 & 2 & 1 & 0 \\ 0 & 0 & 0 & 1 & 0 & 0 \\ 0 & 0 & 0 & 1 & 0 & 0 \\ 0 & 1 & 2 & 3 & 2 & 0 \\ 0 & 0 & 1 & 1 & 0 & 0 \\ 0 & 0 & 1 & 1 & 0 & 0 \\ 0 & 0 & 1 & 1 & 1 & 0 \\ 0 & 1 & 2 & 2 & 1 & 0\end{array}$

